\title{
REFORMA CURRICULAR NO ENSINO MÉDICO: \\ ESTUDO DE CASO DE UMA ESCOLA DE MEDICINA
}

Regina Helena Petroni Pontes

Tese de doutorado apresentada ao Departamento de Prática de Saúde Pública da Faculdade de Saúde Pública da Universidade de São Paulo para obtenção do grau de Doutor.

Área de CONCENTRaÇão: SERViços de SAÚde Pública

ORIENTADORA

Profa Titular Marcia Faria WestPhal

São Paulo-2001 
Dedico esta tese à minha mãe Regina e aos meus irmãos Carlos e Angelo.

À minha mãe, minha amiga e mais importante mestra, que trabalhou incansavelmente para proporcionar aos filhos as oportunidades que ela jamais teve e que construiu sozinha com sua garra e sua luta uma familia repleta de amor.

Aos meus irmãos, pelo amor, ajuda e preocupação demonstrados diariamente.

Aos três, que jamais poupam esforços para me apoiar, me ajudar e me dar suporte em todas as situações, a vocês meus sinceros agradecimentos. 
À Prof ${ }^{a}$ Eliete Salomon Tudisco (in memorian) Grande mulher, mestra, mãe e profissional, exemplo de generosidade, que falta você me (nos) faz! 


\section{Agradecimentos}

À Universidade do Novo México, aos alunos e aos entrevistados pela disponibilidade e paciência com que me receberam; ao pessoal do Teacher and Educational Development pela recepção e constante apoio.

A Prof $\mathrm{Dr}^{\mathrm{a}}$ Márcia Faria Westphal pela oportunidade oferecida e pelo incentivo e apoio na elaboração deste trabalho.

À Prof ${ }^{\mathrm{a}} \mathrm{Dr}^{\mathrm{a}}$ Nina Wallerstein por me receber tão carinhosamente e me ajudar na idealização deste trabalho.

Ao Prof. Dr. Stewart Paul Mennin por me abrir a possibilidade de vivenciar uma fantástica experiência de aprendizagem.

A Prof $\mathrm{Dr}^{\mathrm{a}}$ Eleonora Menecucci Oliveira, ao Prof. Dr. Nildo Alves Batista e ao Prof. Dr. Fernando Lefèvre e à Prof ${ }^{a} \mathrm{Dr}^{\mathrm{a}}$ Regina Giffoni Marsiglia pelas valiosas sugestões e real ajuda com que me brindaram.

À $\mathrm{Dr}^{\mathrm{a}}$ Lynne Fullerton, mi hermana americana, pela acolhida amistosa e por me ensinar a sobreviver e a aprender uma nova cultura.

À $\mathrm{Dr}^{\mathrm{a}}$ Gladys B. Angel que realmente acompanhou passo-a-passo a elaboração desta tese desde o momento que cheguei ao Novo México até o momento da partida, pela ajuda, sugestões e acolhimento, e ao Prof Dr. Frank Angel do College of Education of University of New Mexicu, pelas preciosas discussões.

Aos meus companheiros de trabalho, Eliana, Simone, Myrian, Ana Lúcia, Ana Paula, Clarice, Mariangela, Maria Edith, Rosana, Bel, Lia e Lucia pela amizade, ajuda e estimulo nas minhas diferentes necessidades.

À $\mathrm{Dr}^{\mathrm{a}}$ Miriam Ribeiro de Lima, pela ajuda fundamental nos derradeiros momentos quando eu já estava sem fôlego, pelas discussões verdadeiramente estimulantes e pela gostosa amizade.

A $\mathrm{Dr}^{\mathrm{a}}$ Rosilda Mendes pela amizade e ajuda fundamental em momentos críticos.

À Mirdes Marcilli Petroni pela sistematização das referências bibliográficas.

Ao pessoal da Biblioteca da Faculdade de Saúde Pública pela revisão bibliográfica final.

Ao Prof. Marcio Guimarães de Araújo pela revisão do texto.

A Prof Helena Mendes Procópio de Araújo Ferraz, pela amizade, pela preciosa ajuda na revisão e magnifícas sugestões. 
Aos meus sobrinhos Vinicius, Paula, Érica, Fernando, Carla, e às minhas cunhadas Salete e Mirdes, por todos os momentos felizes que temos partilhado e porque é muito bom ter uma família assim.

Ao Walter, pelo apoio, afeto e incentivo constantes.

A Regininha e ao Reinaldo meus grandes amigos de todas as horas e (que horas!)

A minha prima Rosa, pela constante ajuda, estímulo e amizade que construimos ao logo de nossas vidas.

À minha prima Zelinda, pela ajuda, amizade e preocupação.

A minha querida Ana Maria Girotti Sperandio que foi quem verdadeiramente me incentivou a me aventurar fora do pais.

Ao CNPq pela bolsa de estudos.

À UNIFESP. 


\section{Resumo}

Objetivo. Esta pesquisa tem por objetivo identificar, analisar e sintetizar princípios, conceitos e práticas em educação médica em uma Escola de Medicina com um currículo baseado em problemas orientado para a comunidade, através do estudo da reforma curricular da Escola de Medicina da Universidade do Novo México.

Métodos. Foi realizado um estudo de caso que incluiu observação participante, análise documental e entrevistas com professores e administradores. As observações incluiram múltiplas sessões tutoriais com alunos, seminários de desenvolvimento dos docentes, oficinas de trabalho e reuniões de planejamento. Foram analisados documentos do currículo e da política institucional, além da revisão de publicações.

Resultados. São utilizadas múltiplas abordagens pedagógicas na Escola de Medicina da Universidade do Novo México: a Aprendizagem Baseada em Problemas (ABP) é um fator significante na aprendizagem e na construção do conhecimento dos alunos; a exposição precoce à prática clínica e a educação orientada à comunidade são fundamentais para a reforma curricular realizada. A avaliação dos alunos é parte importante da aprendizagem e é um processo constante ao longo do curriculo. Um componente fundamental da abordagem pedagógica empregada é a necessidade de desenvolver as habilidades educativas dos professores. Várias estratégias diferentes são usadas na educação e desenvolvimento de liderança entre os professores, incluindo reuniões semanais para discussão dos tutoriais, reuniões especiais de diálogo entre os tutores, treinamento de habilidades, revisão de questões relativas à prática e à avaliação, revisão anual da educação, reuniões mensais de implementação de currículo, reunião de grupo de políticas educacionais e realimentação freqüente dos alunos sobre suas experiências de aprendizagem. Todos estes elementos são essenciais para a implementação e melhoria do processo educacional. 
Conclusões. A aprendizagem ativa centrada no aluno e realizada em pequenos grupos, a experiência precoce supervisionada em cuidados primários na comunidade, a Aprendizagem Baseada em Problemas e a integração das ciências básicas e clínicas (via $\mathrm{ABP}$ ) são significantes contribuições na educação dos alunos de medicina. $\mathrm{O}$ desenvolvimento dos professores em métodos educacionais contemporâneos e o trabalho dos comitês na integração do currículo são aspectos fundamentais no planejamento, desenvolvimento e implementação do currículo de educação médica. 


\section{Summary}

Objective. The objective of this research was to identify, analyze and synthesize the principles, concepts and practices in medical education in a communityoriented, problem-based curriculum as expressed through the study of curricular reform at University of New Mexico School of Medicine.

Methods. The primary method consisted of case study that included participatory observation, documental analysis and interviews of professors and administrators. The observations included multiple tutorials sessions with students, and repeated faculty development seminars, workshops, and planning meetings. Institutional policy and curriculum documents, in addition to peer reviewed publications, were analyzed.

Results. Multiple pedagogical approaches are used at University of New Mexico School of Medicine. Early exposure to clinical practice together with studentcentered, small-group, problem-based learning (PBL) are significant factor in the learning and knowledge construction among students. Assessment of students is a very important part of the learning and is a constant process throughout the length of the curriculum. A major component of the pedagogical approach is built upon faculty skills and interest in medical education. Several different strategies are used in the education and leadership development of faculty, including; weekly meetings for discussion of tutorials, special tutor dialogue sessions, multiple skills training sessions, review of assessment questions and practices, annual education retreats, monthly meetings of curriculum implementation and educational policy groups and frequent feedback from students about their learning experiences. All of these elements are critical for the implementation and improvement of the educational process.

Conclusions. The active learning through early guided experiences in community-based primary care settings, student-centered, small-group, problembased learning and the comprehensive integration of the basic and clinical sciences (via PBL) form the core of the most significant contribution in the students' education. The development of the teachers in contemporary educational methods, and the work of multiple committees in the integration of the curriculum are fundamental aspects in the planning, development and implementation of the medical education curriculum. 


\section{Índice}

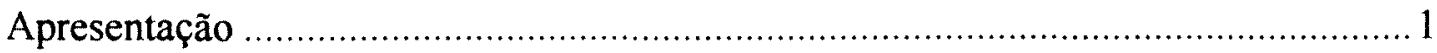

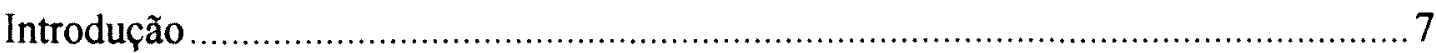

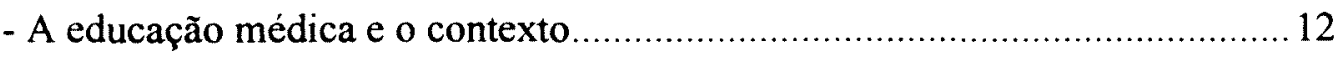

- Outros atores coletivos: as associações e as conferências que influenciaram a educação médica ...........................................................25

- As novas diretrizes e bases da reforma curricular no Brasil ..........................27

Diretrizes curriculares nacionais do curso de graduação em medicina..............28

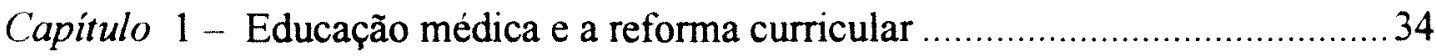

- O significado de currículo e as reformas curriculares na educação médica ...35

- O processo educativo e a geração de conhecimento ..........................................38

- O processo de conhecimento e as abordagens educativas ...............................40

- Propostas metodológicas inovadoras para a educação médica ..........................43

Objetivos 49

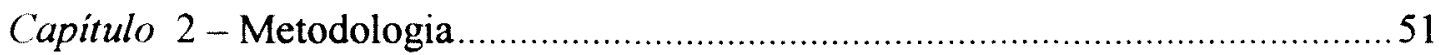





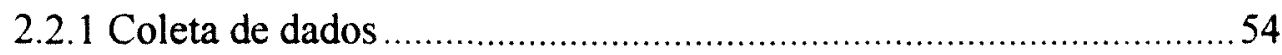

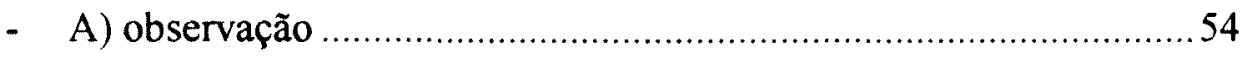

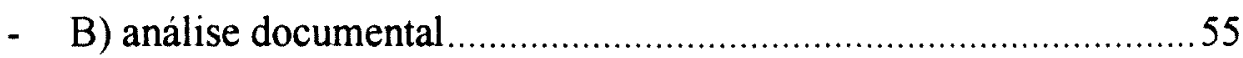



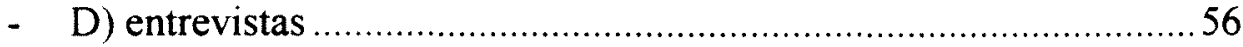

2.3. A sistemática para organização e interpretação do dados ............................57

O Discurso do Sujeito Coletivo..........................................................58 
Capitulo 3 - Cenário

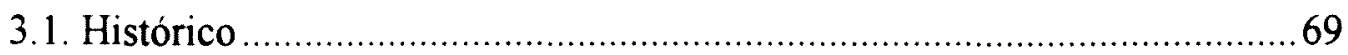

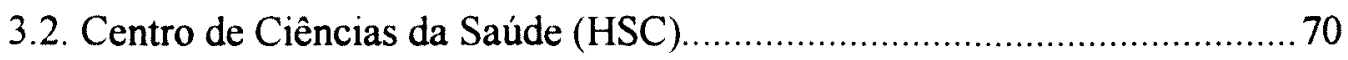

3.3. Perfil dos estudantes da Escola de Medicina do Novo México ……….......71

3.4. Situação de Saúde do Estado do Novo México …………………............. 72

3.5. O sistema de saúde do Estado do Novo México ........................................ 75

Capítulo 4 - Resultados - O caso da Escola de medicina da Universidade do Novo México

4.1. O currículo paralelo - Currículo de Cuidados

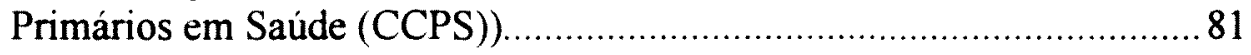

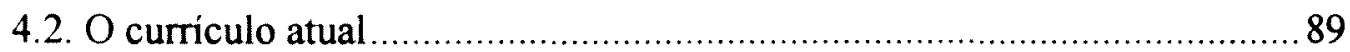

4.2.1. Organização curricular .............................................................93

4.2.2. Metodologia de ensino na Escola de Medicina da UNM ................98

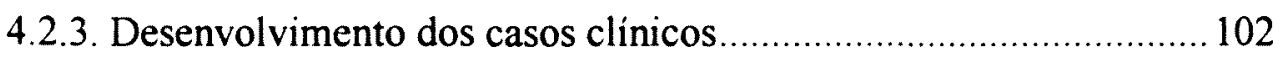

4.2.4. Desenvolvimento educacional dos professores (TED) ……............ 105

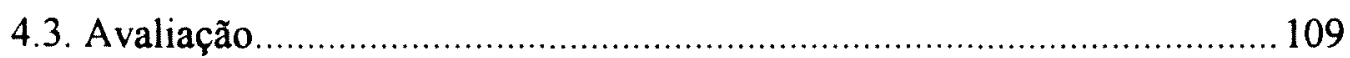

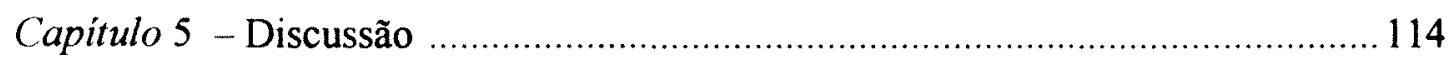

Capitulo 6 - Conclusões e considerações finais .................................................... 137

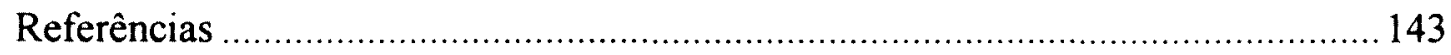

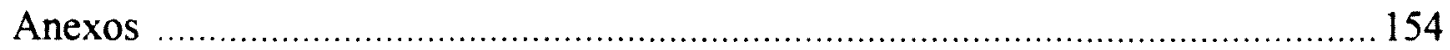




\section{Apresentação}

O presente trabalho objetiva estudar a reforma curricular em uma escola médica, buscando identificar princípios, conceitos e práticas relevantes para a educação médica na atualidade.

$O$ interesse pela temática da educação médica foi surgindo gradualmente em função do meu trabalho na Universidade Federal da São Paulo - Escola Paulista de Medicina.

Em 1985, iniciei meu trabalho em Educação em Saúde Pública no Centro de Saúde do Departamento de Medicina Preventiva da referida escola. Era um momento em que havia uma grande movimentação na área da saúde pública e na definição de políticas de saúde. Estava em curso a Reforma Sanitária que trazia em seu bojo uma mudança sem precedentes na área da saúde, que culminou com o Sistema Único de Saúde (SUS).

Neste sistema, Saúde foi definida como um direito universal, resultante de condições de vida e trabalho e "garantida mediante políticas sociais e econômicas, visando à redução do risco de doença e outros agravos e ao acesso universal e igualitário às ações e serviços para sua promoção, proteção e recuperação" (BRASIL 1988).

Com a mudança do paradigma da saúde tornou-se necessária a mudança na formação de recursos humanos, que continua até hoje assentada no paradigma anterior, de caráter eminentemente biologicista, de hegemonia médica, de atenção individual especializada e de caráter eminentemente curativo.

A participação em um trabalho com uma equipe multiprofissional recémformada, possibilitou um grande crescimento para todos os profissionais. Foi um periodo de grande aprendizagem por parte da equipe do Centro de Saúde, que naquele momento era composta por sanitaristas, enfermeiros, médicos, psicólogo, nutricionista, assistente social e educadora de saúde pública (a autora do presente trabalho). Porém, a maioria dos profissionais se debatia com a mesma formação tradicional característica das universidades brasileiras na área da saúde. Ao invés de uma atuação multidisciplinar ou até transdisciplinar em função da formação tradicional e isolada de cada uma das profissões na área da saúde, o que acontecia era 
um somatório de conhecimentos. Na prática tal fato gerava uma atuação fragmentada de cada um dos profissionais.

Havia por parte da equipe um grande contato com alunos de enfermagem e de medicina. O contato mais estreito se dava com os alunos do $5^{\circ}$ ano médico, durante o internato, e com os residentes de medicina preventiva, que permaneciam por um período de dois anos em estágio no Centro de Saúde e em outras unidades da região, que faziam parte do Projeto de Integração Docente Assistencial - PIDA, no qual a equipe multiprofissional do Centro de Saúde tinha um papel secundário.

Os trabalhos de comunidade realizados em conjunto com os alunos eram de caráter pontual e desenvolvidos em escolas e creches próximas, ou seja, não havia de fato um trabalho extra-muros com a efetiva participação da população, tanto pelas dificuldades do dia-a-dia, como pela falta de formação da equipe, ou pelas variadas e diferentes concepções existentes entre os trabalhadores da unidade e também no Departamento que dirigia o Centro de Saúde

Havia uma grande preocupação por parte da equipe com o processo de ensino e a formação dos recursos humanos em saúde, em particular com relação aos alunos de medicina e enfermagem e também com o treinamento de pessoal auxiliar.

Foi nesse contexto que a equipe não só se envolveu no desenvolvimento das ações do Centro de Saúde, mas também estendeu sua ação às atividades educativas com os alunos. Ao longo dos anos, a equipe foi ampliando sua formação em saúde coletiva e seu entendimento das finalidades da educação junto aos alunos da medicina.

Assim, foi se constituindo uma nova concepção de educação médica explicitando alguns conflitos com outras diferentes concepções de ensino vigentes na universidade, cuja preparação estava voltada para atender somente problemas individuais relacionados à mudança de hábitos e comportamentos, sem ưma dimensão coletiva. E a equipe debatia-se dia-a-dia entre o enfrentamento da dor e do sofrimento de pessoas concretas que procuravam o Centro de Saúde em busca de atenção e em como enfrentar a doença como um fenômeno social determinante desses problemas, encaminhando ações coletivas de intervenção sobre eles.

Em 1990, a pesquisadora deixou a Escola Paulista de Medicina e foi trabalhar no Distrito do Campo Limpo da Prefeitura Municipal de São Paulo, especificamente 
no Departamento de Recursos Humanos, na Seção de Treinamento e Desenvolvimento de Pessoal, que também contava com uma equipe multiprofissional tal e qual a do Centro de Saúde. Nesse período, urgia a reorganização do sistema de atenção em saúde em torno do modelo do Sistema Único de Saúde, SUS. Os esforços para a adoção de práticas de saúde que atendessem aos princípios de universalidade, acessibilidade, equidade e integralidade estabelecidos no SUS eram imensos. A realização de encontros, treinamentos, seminários, oficinas, cursos e o Projeto Larga Escala realizados pelo Departamento de Recursos Humanos era muito intensa no esforço da construção do Distrito de Saúde.

Através dessas atividades deparou-se com mil dificuldades provenientes em parte da formação dos profissionais de saúde. Havia um desconhecimento do que era - SUS, de como incluir as condições concretas de vida da população ao se estabelecerem prioridades de saúde e de serviços com diferentes níveis de complexidade.

Enfim, havia uma grande resistência à implantação de um novo modelo que fatalmente levaria à modificação de antigos e arraigados hábitos dos profissionais de saúde.

Talvez este tenha sido o momento em que mais fortemente se sentiu o impacto que a formação de todos os profissionais de saúde e, em particular a dos médicos. tem na prática de saúde e portanto, a importância dessa formação nas dificuldades encontradas para a implantação de um novo modelo de atenção à saúde.

Com o término da Administração Municipal - Gestão Luiza Erundina, em 1992 e o início de outro governo, houve o rompimento com a implantação do SUS e, de maneira anticonstitucional e antidemocrática, foi iniciada a adoção do PAS - Plano de Assistência à Saúde - no município de São Paulo. Neste momento houve um processo de pulverização dos profissionais de saúde contrários ao programa proposto, com transferências para outras Secretarias e fechou-se, assim, um outro ciclo de trabalho.

Em 1995 a autora voltou para o Centro de Saúde da Escola Paulista de Medicina, que foi então transformada na Universidade Federal de São Paulo (UNIFESP). Nessa ocasião, um grupo de alunos procurou o Centro de Saúde solicitando um trabalho prático, no qual eles estivessem em contato com usuários 
desde o primeiro ano. Assim surgiu o projeto INOVAS (Introdução Orientada para Vivências em Atividades de Saúde), projeto que visava ao reconhecimento da problemática da população que vivia no entorno do território do Centro de Saúde e na discussão junto à população para fazer frente aos problemas levantados.

Muitos desses alunos conheciam o projeto UNI [Uma nova iniciativa em educação dos profissionais de saúde: unido com a comunidade], realizado por outras universidades no país e solicitavam mudanças neste mesmo sentido. Para atender a esta solicitação do alunos, visitamos a Universidade Estadual de Londrina e iniciamos um projeto piloto e voluntário que foi realizado por um período de três anos, quando houve então a oportunidade de se criar a disciplina de Saúde Coletiva (ITO 1994).

Nesse mesmo período, a Universidade Federal de São Paulo iniciou um processo de reforma curricular que teve inicio em 1997 e que ainda está em curso.

Como coloca PAIM (1996), dentro das escolas médicas (e a UNIFESP não é uma exceção), competem entre si na formação médica diferentes projetos políticoideológicos, e esse sempre foi um dos maiores desafios enfrentados pelos profissionais da saúde coletiva. Existem conflitos nos objetivos de formação do aluno de medicina: um profissional formado para o SUS (e qual SUS?) ou para a assistência médica supletiva, ou para empresas, ou para cooperativas médicas e ou para a medicina liberal reatualizada? Tais conflitos não se resolvem nem com a reestruturação do currículo que visa ao reajuste de carga horária, nem com a supressão ou criação de novas disciplinas, nem com a enunciação de objetivos educacionais e nem com as discussões sobre o tipo de médico que queremos formar (PAIM 1996). Concordo com o autor, quando coloca que as respostas concretas para estes conflitos passam por projetos de luta política e teórica que atravessam a escola médica e alcançam a organização social dos serviços de saúde, onde, em uma outra perspectiva, o modelo pedagógico e o trabalho seriam os espaços privilegiados de constituição dos sujeitos sociais. Passam por iniciar processos que produzam fatos sociais e promovam mudanças no interior das instituições de saúde e de ensino, como as experiências que estão sendo vivenciadas em outras escolas do Brasil, como por exemplo a de Marilia e de Londrina, que estão articulando iniciativas entre a universidade, os serviços de saúde e as organizações sociais dentro de seu currículo. 
Em sintese, a realização de uma investigação sobre reforma curricular no ensino médico se deu por causa da vivência no espaço pedagógico da Universidade e da prática de ensino integrada à assistência; da percepção da fragmentação do saber, fruto de uma pedagogia tradicional que perpassa a formação dos alunos de saúde; da busca de um conhecimento das possibilidades e dos limites de uma nova proposta metodológica.

Com todas estas preocupações em mente, restava buscar um lugar para o estudo. Para a realização desta investigação, buscaram-se escolas onde as reformas curriculares já haviam sido implantadas. A UNIFESP, iniciou a reforma do currículo médico em 1997, porém ela ainda está em curso. No Brasil, nesse mesmo período, outras escolas iniciaram um processo de reforma curricular ainda inconcluso. No levantamento e nos contatos que foram sendo realizados, houve a possibilidade de ir à Escola de Medicina do Novo México pois existe um intercâmbio entre esta Universidade e a Faculdade de Saúde Pública. A referida escola é uma referência em termos de inovação curricular pois implantou a partir da década de 80 um currículo experimental denominado Currículo de Cuidados Primários em Saúde (CCPS) com orientação para a comunidade. Em 1992, houve uma reestruturação com a fusão de ambos currículos, o experimental e o convencional. A longa experiència em termos de curriculo foi um atrativo a mais para justificar a escolha dessa escola de Medicina.

\section{Organização do estudo}

$\mathrm{Na}$ introdução, procura-se delinear a dinâmica do contexto brasileiro e mundial na área da educação médica, fazendo-se uma breve revisão da literatura.

No capitulo 1, enfoca-se o significado de curriculo e as reformas curriculares na educação médica, e a articulação entre o processo educativo e a geração de conhecimentos; por fim a abordagem educativa inovadora na educação médica da atualidade.

No capítulo 2, apresenta-se a metodologia adotada, o processo de coleta de dados e o referencial utilizado para o tratamento dos dados, especialmente das entrevista realizadas. 
No capitulo 3, descreve-se o cenário da pesquisa, que inclui um breve histórico da cidade de Albuquerque, onde se localiza a Universidade do Novo México (UNM), o perfil dos estudantes e a atual situação de saúde no Estado do Novo México, Estados Unidos da América.

O capítulo 4 é composto pelo Estudo de Caso realizado na Escola de Medicina do Novo México, a partir das observações dos alunos e dos docentes nas atividades cotidianas, da análise documental e das entrevistas realizadas.

O capitulo 5 contém a discussão do caso à luz dos acontecimentos atuais em termos de educação médica no Brasil e no mundo.

O capítulo 6 busca fazer uma síntese contendo as conclusões e considerações finais.

Também fazem parte do presente trabalho, uma série de anexos e a bibliografia utilizada para o seu desenvolvimento. 


\section{Introdução}


Imagine-se um monge medieval europeu, vivendo no século XIII, que tenha entrado em estado de catalepsia, morte aparente e coma. Seu corpo (surpreendentemente vivo) foi guardado nas catacumbas do convento durante centenas de anos até que no fim do século $X X$ foi trazido intacto para outro convento, no centro de Såo Paulo, tornando-se objeto de veneração. Um dia, por razóes desconhecidas ainda da Ciência, despertou de sua letargia profunda e saiu a caminhar pela cidade. Quase entrou em desespero! Havia milhares de pessoas pelas ruas, um ruido ensurdecedor, um ar que ardia nos olhos e um odor de decomposiçăo; passavam objetos de metal em alta velocidade, com humanos aprisionados dentro, havia buracos de onde entravam e saiam pessoas continuamente, todos com roupas estranhas. O mais espantoso eram as casas, redivivas torres de Babel, e, choque supremo, pequenas tendas de ferro expondo e vendendo objetos semelhantes a manuscritos, mas com letras diferentes. O monge parou, admirado, diante de uma delas e observou com horror que estavam à mostra similares de livros estampando imagens perfeitas de mulheres $e$ homens completamente nus. Correu dali, tapando a visão demoniaca. Correu sem rumo e às cegas até que, tateando por uma porta, por ela entrou e, ainda sem enxergar direito, disparou pelo corredor até achar uma sala vazia: nela precipitou-se, sentando esbaforido. De repente, percorreu a sala com o olhar e, pela primeira vez, acalmou-se. 0 ambiente era muito familiar e seguro e quase tudo ali presente ele já conhecia: o mobiliário, a disposição dos móveis, a decoração, a maior parte dos objetos de trabalho. Estava em uma sala-de-aula!

Mario Sergio Cortella,1998, pág.119 
Nos últimos vinte anos, observa-se no mundo inteiro e também no Brasil numerosa produção de estudos e artigos acerca da educação médica (SCHRAIBER 1980; LOPES PONTES 1982; CASTRO e SALGADO 1987; SOBRAL 1991; DUTRA DE OLIVEIRA 1993; GONÇALVES 1990; PAIM 1994; BERBEL 1994; VENTURELLI 1997; FEUERWERKER 1998; ALMEIDA 1999; MERHY 1999; CINAEM, 2000).

Ao longo desses anos mudou-se também o perfil daqueles que vinham se dedicando ao estudo de temas afeitos à educação médica. Esta passou a ser uma questão estudada por pedagogos, filósofos, sociólogos e outros profissionais, além dos médicos, o que modificou qualitativamente a abordagem do assunto (REGO 1998).

$\mathrm{Na}$ literatura, identificaram-se várias publicações que clamam por reformas na educação médica e chamam a atenção para o compromisso social da escola médica em relação à saúde da população. Os autores falam em mudanças no sentido do bemestar coletivo, na modificação das ações individuais que não estão necessariamente vinculadas aos interesses da comunidade ou, ainda, na formação de um médico capaz de atender às necessidades de saúde da comunidade (LOPES PONTES 1982; CASTRO e SALGADO 1985; KAUFMAN 1985; BLOOM 1989; DUTRA DE OLIVEIRA 1993; GONÇALVES 1990; GLICK 1991; PAIM 1994; BERBEL 1994; SCHRAIBER 1997; VENTURELLI 1997; FEUERWERKER 1998; REGAN-SMITH 1998; ALMEIDA 1999; BOADEN e BLIGH, 1999; MERHY 1999; CINAEM 2000).

Existem várias dificuldades que cercam a reforma da Educação Médica. Uma delas é que o complexo médico-assistencial e o médico é que determinam o modelo de assistência vigente. Este valoriza a capacidade resolutiva pontual, dispersando a visão de conjunto do estado de saúde do individuo e das suas relações com as condições econômicas, políticas e sociais (FERREIRA 1994).

Nesse contexto, torna-se muito importante a necessidade de enfrentar o desafio e discutir as mudanças na formação profissional, pois o conjunto das profissões de saúde é um dos mais diretamente afetados por todas as transformações que estão ocorrendo no mundo. Com as mudanças na economia mundial e nos enfoques políticos, com a privatização de atividades em que o lucro passa a ser a questão central, com a privatização da educação e da atenção à saúde e com a consequente 
perda de direitos que estamos atravessando no momento atual, vai se destruindo a sustentabilidade de melhores condições de vida, de acessibilidade e de eqüidade como processo de crescimento e de bem-estar econômico das sociedades (VENTURELLI 1997).

Devido às precárias condições de vida e saúde no nosso pais, à ênfase na natureza econômica da área da saúde com a assistência médica cada vez mais dispendiosa, exercida por prestadores privados, com a incorporação tecnológica desenfreada e a mudança nos processos de gestão (CARVALHEIRO 1999), se faz necessário repensar tanto a relação entre a medicina e a sociedade, e sobre as opções de que a sociedade dispõe para obtê-la do ponto de vista social e individual, como a maneira como vem acontecendo a Educação Médica na atualidade (FEUERWERKER 1998).

Como resultado das políticas impulsionadas pelo Fundo Monetário Internacional (FMI), pelo Banco Mundial (BM) e pelo Banco Interamericano de Desenvolvimento (BID), assistimos à abertura da nossa economia a capitais estrangeiros, ao endividamento e reestruturação do Estado por meio de privatizações e uma conseqüente diminuição dos beneficios sociais. Com a aceitação de projetos de reforma orquestrados pelo FMI, BM e o BID, a saúde deixou de ser um bem público para converter-se em um bem privado, deixou de ter um caráter de direito universal, cuja responsabilidade seria do Estado, para converter-se em um bem de mercado que os indivíduos devem adquirir (IRIART, MERHY E WAITZKIN 2000).

As reformas implementadas pelo neoliberalismo em poucos anos promoveram no mundo todo a destruição de um século de conquistas sociais. Por exemplo, no âmbito dos direitos trabalhista e previdenciário, essas conquistas deixaram de existir ou se esvaziaram. O ganho de capital não respeita nada. Não respeita a vida ou a saúde, e até mesmo partes do corpo humano vão se transformando em mercadoria; o credo neoliberal é imposto aos povos com as regras do fundamentalismo monetário, que não admite dissidências. É o que se evidenciou quando o Banco Mundial e o FMI subordinaram sua ajuda ao compromisso dos governos de desmantelar os sistemas de saúde pública e de previdência social (BERLINGUER 1999).

$O$ fato de o globo não ser mais uma figura astronômica, com um conglomerado de nações, mas sim um território no qual todos se encontram atielados 
e antagônicos, requer que se faça um grande esforço de reflexão e imaginação para explicar o que está acontecendo no mundo. A abundância das metáforas, imagens e figuras para explicar as transformações do mundo no início deste século, as possibilidades de interpretações, interrogações e respostas em relação à globalização são múltiplas, tanto no imaginário científico, filosófico, como no artístico (IANNI 1996). Dentro do contexto de globalização vêm ocorrendo diversas transformações nas últimas décadas, seja no mundo do trabalho, seja nas relações entre as pessoas, nos segmentos sociais, na produção e consumo de bens. As consequeências da globalização ultrapassam as de ordem econômica e envolvem também os aspectos culturais e sociais (FEUERWERKER e SENA 1999).

O que se viu durante vários anos foi um distanciamento, a cada dia mais largo, entre a evolução da economia e a melhoria das condições de vida de grupos sociais e culturais. A globalização dos mercados, da tecnologia, e a mundialização da cultura, nos situaram a todos num "mesmo mundo". Porém um mundo diferenciado e desigual (IANNI 1997).

Este é um periodo de transição paradigmática, como sugere SANTOS (1997): “...por baixo de um brilho aparente, a ciência moderna, que o projeto de modernidade considerou ser a solução privilegiada para a progressiva e global racionalização da vida social e individual, tem-se vindo a converter, ela própria, num problema sem solução, gerador de recorrentes irracionalidades. Penso hoje que essa transição paradigmática, longe de se confinar no domínio epistemológico, ocorre no plano societal global "(p.34)

Em sintese, dentro de um contexto tão complexo, a formação de profissionais e técnicos da área da saúde é um tema de alta relevância. $O$ modelo de formação aceito como hegemônico está longe de poder atender às necessidades da população toda, apresentando restrições técnicas e sociais, de cobertura e de distribuição geográfica, não contribuindo para a melhoria da qualidade de vida da comunidade.

No caso da educação médica, é preciso refletir sobre sua inserção num contexto político e social e os contornos que assume ante as tendências ideológicas hegemônicas do momento histórico.

No momento atual, com a aprovação das novas Diretrizes Curriculares Nacionais pelo Ministério de Educação, abre-se a possibilidade de um movimento de 
transformação na educação médica brasileira vinculada às necessidades de saúde dos indivíduos e populações.

A reforma da educação médica está colocada em um momento de profunda crise da sociedade. Para este setor isso implica a reorganização da prática médica, da assistência médica, e da formação de um profissional adequado às demandas sociais na atualidade.

\section{A EDUCAÇÃo MÉdica E O CONTEXTO NO BRASIL E NO MUNDO}

A fim de contextualizar a problemática da educação médica, das reformas realizadas e da sua relação com a organização dos serviços de saúde, optamos por fazer um breve histórico sobre o tema que nos forneça uma base de conhecimento para entender o que ocorreu ao longo do tempo e como os movimentos internos ou externos ao país influenciaram nas mudanças do ensino médico.

As propostas de mudança na formação médica no século passado correspondem a momentos sociais e econômicos bastante precisos, que passam pelo entendimento do processo saúde-doença segundo as diferentes abordagens existentes, baseados na concepção predominante do que seja tal processo em um determinado momento histórico. Em sintese, os modelos de saúde, a prática médica e a Educação Médica em vigor em uma determinada sociedade estão baseados na concepção predominante do que é o processo saúde-doença (MINAYO 1994).

Decidimos por não reconstruir a história de evolução da questão da saúde desde os seus primórdios, o que não era o objetivo deste trabalho, tecendo apenas algumas considerações dos aspectos importantes para a discussão da Educação Médica, até porque existem diferentes possibilidades de abordagem deste tema.

De uma maneira muito sintética, começamos levantando dois acontecimentos que tiveram grande impacto na explicação dos problemas de saúde: um foi possibilitado pela instrumentação poderosa do microscópio com a identificação do agente causador da doença, a partir das investigações de Pasteur e Koch. Esta descoberta inaugurou a Era do Germe na segunda metade do século XIX e ocasionou uma grande transformação da medicina, de uma profissão orientada para as pessoas para uma outra orientada para a doença (NUNES 1998). 
Outro acontecimento de extrema importância foi a Revolução Industrial (meados do século XVIII) e as intensas modificações na organização da produção e das sociedades. As doenças que aconteciam naquele periodo eram grandes entraves, do ponto de vista econômico e político, à construção de um nova sociedade industrial. A intensa e desordenada urbanização ocasionada pelas mudanças das famílias camponesas para as áreas urbanas, decorrentes das novas relações de produção que se estabeleciam, causaram problemas críticos de saneamento e habitação. Foram os terriveis impactos que acarretava essa conjuntura nas dramáticas condições de vida dos operários têxteis das fábricas inglesas que desencadearam o início das aplicações de medidas relacionadas, por exemplo, com o abastecimento de água, dejetos e coleta de lixo (STERN 1983, CAMPOS 1987).

Em sintese, as condições de saúde das coletividades humanas, a intensa migração, a urbanização acelerada, a exploração do trabalho do menor, a precariedade das habitações que caracterizaram a fase inicial da Revolução Industrial deram origem a sérios problemas de saúde e agravaram os que já existiam (SILVA 1973).

Dessa época remonta o célebre estudo de John Snow sobre o cólera, em 1824, Villarmé sobre as condições das fábricas têxteis, em 1840, e Engels sobre as condições de vida dos ingleses, em 1844 (ROSEN 1983, NUNES 1998). Era também uma época na qual começaram a surgir a aplicação de procedimentos que, além de diminuir o aparecimento de doenças, favoreciam a manutenção de uma força de trabalho saudável. Na medida em que os operários começavam a se organizar e lutar por melhores condições de vida e trabalho, o que também incluía o acesso à prestação de assistência à saúde, iniciava-se a criação dos primeiros ambulatórios, como uma resposta às intensas tensões sociais (CAMPOS 1987)

Nesse momento, e de maneira oposta ao descrito anteriormente, a saúde era um assunto de interesse público e muitas das medidas visavam controlar a doença nas populações. Era portanto um período em que o conhecimento das doenças baseava-se nas teorias que relacionavam os aspectos ambientais e sociais, embora apoiados em diferentes perspectivas ideológicas e teóricas (NUNES 1998). Durante a primeira metade do século XIX, firmaram-se os vínculos entre saúde, medicina e sociedade, e em 1848 Jules Guérin cunhou o termo "medicina social" para se referir a todo esse processo de análise dos problemas sociais e sua relação entre saúde e dnença, à 
determinação das medidas para a promoção da saúde e a prevenção de doenças, como também à medicina vista como um meio para tratar a desintegração social e outros problemas da sociedade (DONNANGELO e PEREIRA 1976).

Com os problemas sociais e de saúde emergindo, tornou-se necessário estabelecer algum tipo de ação. Os relatórios de Chadwick, na Inglaterra, e de Shattuck, nos Estados Unidos, que descrevem a situação da saúde da população de baixa renda, por exemplo, aparecem no bojo desses acontecimentos e concluem por uma maior intervenção estatal no campo da saúde. SILVA (1973) ressalta que a reforma sanitária, como movimento político, e a saúde pública, como seu correspondente técnico de ação, se desenvolveram com uma pequena participação da medicina ou da profissão médica e tiveram como agentes principais, não o médico, mas sim o engenheiro e o administrador público, quando as ações práticas estavam centradas em medidas de saneamento do meio (SILVA 1973, STERN 1983, CAMPOS 1987).

As medidas de saneamento que foram sendo tomadas foram permitindo a erradicação e controle de várias doenças de massa, principalmente aquelas relacionadas ao saneamento básico. Persistiam porém outras de transmissão direta ou por vetores e para elas se dirigiam os esforços dos estudiosos como Jenner, Koch e Pasteur, o que resultou na identificação de vários agentes etiológicos para a produção de vacinas e soros e no aprimoramento de técnicas (CAMPOS 1987).

A legitimação de uma teoria de contágio e as medidas tomadas para tratar e prevenir as doenças implicaram uma afirmação da medicina como resposta às condições individuais e a utilização do método clínico aplicado ao indivíduo, priorizando a atenção aos processos biológicos. Pelo altos custos, a assistência médica naquele momento era dirigida somente às classes dominantes ou a grupos de trabalhadores qualificados indispensáveis à produção capitalista (CAMPOS 1987).

No final do século XIX e inicio do século XX, com as principais doenças transmissiveis sob controle, os países industrializados procuravam consolidar o controle e a erradicação das doenças por meio do desenvolvimento de leis e de fiscalização sanitária de uma maneira bastante autoritária. As preocupações com o pensamento social em saúde não são recentes na história da saúde no mundo ocidental. Sua formalização através de cursos data do final do século XIX e úmeço 
do século XX, com a criação do curso de medicina social em Munique em 1881, da Escola de Saúde Pública Johns Hopkins em 1916, depois de Harvard em 1913 e do Departamento de Higiene em São Paulo em 1918 (NUNES 1998)

Paralelamente, um informe datado de 1910, realizado por um educador graduado na Universidade Johns Hopkins, causou uma enorme repercussão na organização de serviços e na educação médica. De autoria de Abraham Flexner (FLEXNER 1910), teve uma forte influência na reformulação do ensino médico e de outras profissões de saúde, nos Estados Unidos e no Canadá. Foi depois de décadas incorporada pelos paises da América Latina (RODRIGUEZ-NETO 1987).

O informe propunha, entre outras questões, uma sólida formação em ciências básicas nos primeiros anos do curso de medicina (criação do ciclo básico), dando pouca ênfase aos aspectos de prevenção e promoção de saúde, concentrando-se na atenção médica individual e valorizando a aprendizagem dentro do ambiente hospitalar, com a criação dos hospitais-escola (ALMEIDA 1999).

No Brasil, na primeira década do novo século, com a cristalização das oligarquias estaduais, a prioridade da atuação do governo se voltou ao plano econômico. Dirigida especificamente para o café no mercado internacional e o equilíbrio das contas públicas, tal política levou à deterioração do padrão de vida dos assalariados urbanos. Ao mesmo tempo havia a necessidade do governo de reordenar o espaço urbano e solucionar a situação sanitária da capital e dos portos. Essas ações foram capitaneadas pelo médico sanitarista Oswaldo Cruz, que com o respaldo político-administrativo do governo, criou a polícia sanitária. Essa também foi a fase áurea dos institutos de pesquisa e dos dispensários, que trabalhavam no combate às doenças infecciosas. Em razão das dificuldades advindas da I Guerra Mundial, da exigência do pagamento da dívida externa, da escassez de alimentos e da perda das pequenas conquistas obtidas pela classe operária e sob a influencia da movimentação operária de 1917, desenvolveu-se a organização sindical e ocorreu grandes manifestações da massa trabalhadora. A gripe espanhola de 1918 veio chamar a atenção para a ineficiência da máquina sanitária para evitar o colapso que a doença provocou na capital. A criação do Departamento de Saúde se dá na década de 20 , sob uma forte intervenção estatal de jovens sanitaristas com métodos pautados na bacteriologia e nas teorias da eugenia (CAMPOS 1987). 
Ainda nesse mesmo periodo no Brasil, a Fundação Rockefeller financiou o combate às grandes endemias e a criação dos centros de saúde e dos programas de desenvolvimento comunitário, sob a influência da Escola Johns Hopkins e a fundação do Instituto de Higiene, atualmente Faculdade de Saúde Pública. A saúde pública que vinha ganhando impulso nos paises da Europa e nos Estados Unidos adquire nesse momento a sua expressão prática aqui no Brasil.

O marco teórico do modelo flexneriano de ensino médico foi implantado no Brasil somente a partir da década de 1940 , quando do processo de criação de novas escolas de medicina, enfermagem e odontologia, e da reformulação das escolas já existentes. Era um modelo calcado em uma perspectiva biologicista, individualista, curativa e hospitalar (FEUERWERKER e MARSIGLIA 1996).

Nesse paradigma, o diagnóstico e a terapêutica têm grande relevância, as ações de saúde são essencialmente voltadas ao individuo, excluindo-se delas o contexto social, histórico e ambiental. A prática sanitária está calcada na busca da cura dos indivíduos que manifestam a doença (SANTOS e WESTPHAL 1999). As práticas de ensino originadas nesse modelo persistem até hoje, apesar dos esforços de mudanças, mesmo nos paises que introduziram reformas significativas na organização dos serviços de saúde (PAIM 1994).

Com a era bacteriológica e a revolução científica e tecnológica subsequentes, onde já existiam instrumentos que poderiam ser utilizados na manutenção da saúde dos grupos populacionais, a saúde pública passou a concentrar esforços na aplicação de medidas de combate às doenças transmissiveis, crescendo então papel do médico na aplicação de medidas preventivas (SILVA 1973).

Os movimentos de medicina preventiva e medicina integral foram outros marcos teóricos importantes na educação médica. Surgidos em meados do século XX nos Estados Unidos, apresentam diferentes caracteristicas, porém se entrelaçam muitas vezes ao longo do tempo e nos diferentes países.

A medicina preventiva já existia desde a fundação da Escola Johns Hopkins, mas somente foi reconhecida como especialidade em 1949 pelo American Board of Medical Specialtes, relacionada à pós-graduação em educação médica. Tinha como foco elucidar e mitigar os fatores causais de doenças nos indivíduos e populações. Embora a maioria dos especialistas tivessem por função o cuidado clínico, a maior 
ênfase era dada na promoção de saúde e na prevenção de doenças em bases populacionais (LASKER 1997)

Para SILVA (1973), a medicina preventiva estava ligada enquanto movimento ideológico à medicina integral, mas também vinculava-se com a saúde pública e em algumas instituições, à medicina social (SILVA 1973).

No mesmo periodo tomou vulto um novo movimento ideológico no interior das instituições de educação médica americanas, denominado de medicina integral, em meados de 1940 (CAMPOS 1987). O movimento iniciou-se pela consciência dos novos problemas de saúde e da inadequação dos sistemas de saúde pública sob a égide do Estado e da assistência médica de iniciativa individual. Passada a crise internacional e aparentemente vivenciando-se um período estável de impulso econômico e de um clima de otimismo dominante, resultante de uma filosofia racionalista, começou a aparecer um projeto, mais de adaptação do que de mudança estrutural, que tinha o sentido de diminuir a crise gerada pela inadequação do sistema de saúde. Tratava-se de uma tentativa de aprimoramento da medicina individualista para corrigir as distorções das instituições de saúde, que se tornaram obsoletas ante o progresso técnico e as novas exigências sociais, e buscava suavizar as tensões de uma sociedade em rápida transformação (SILVA 1973).

Por outro lado, havia a necessidade de atenuar os graves problemas econômicos e sociais dos países do Terceiro Mundo, pois a situação de miséria fomentava a agitação social e ameaçava o equilíbrio de forças estabelecidas pelas potências nos diversos continentes, além de reduzir a capacidade laboral e o poder aquisitivo de grandes contingentes humanos. Em conseqüência disso, desenvolveramse políticas de intervenções estatais nos setores sociais, através de planos integrados em que os problemas de saúde fossem abordados dentro de uma perspectiva global de desenvolvimento. Nessa perspectiva, era fundamental integrar a prevenção e a cura entre as diversas profissões de saúde e as instituições prestadoras de serviços. Procurou-se aumentar a extensão de cobertura de serviços a todos os segmentos da população, a partir de uma visão racionalizadora da utilização de recursos. Através de mecanismos de Previdência Social é que procurou-se gerar um fundo capaz de custear a prestação de serviços em diferentes níveis de complexidade, para todas as pessoas independente de sua condição social (CAMPOS 1987) 
No final da década de 1950, por influência da Organização Pan-Americana de Saúde (OPAS), como ocorrera nas escolas médicas americanas, o ensino de medicina, enfermagem e odontologia no Brasil foi marcado pelos modelos de medicina integral e pela criação dos departamentos de medicina preventiva, com a finalidade de orientar os alunos em programas médico-sociais de higiene e prevenção. As ações desenvolvidas por esses departamentos envolveram estudantes de medicina e docentes em programas de assistência domiciliar e familiar realizados fora dos hospitais - as chamadas atividades extramuros (FEUERWERKER e MARSIGLIA 1996).

Inspirada em uma ideologia originada no interior da escola médica americana, a criação da medicina preventiva como nova disciplina do currículo médico pretendeu ter o papel de disciplina-síntese, para fazer frente à extrema fragmentação do conhecimento médico (SILVA 1973). Do ponto de vista prático esperava-se que as escolas médicas incorporassem aspectos de prevenção e promoção de saúde à prática médica, bem como a uma nova concepção do processo saúde-doença (FEUERWERKER 1998).

O movimento de medicina preventiva foi difundido na América Latina através do seminário de Viña del Mar, Chile (1955), e Tehuacán, México (1956). Como prática ideológica, efetuou uma crítica à ideologia que pretendia substituir, questionando a prática médica vigente pela ausência de racionalidade, pela especialização, pelo enfoque biologicista, pelo caráter individualista e pela inadequação dos profíssionais às necessidades de saúde da população (PAIM 1982). Já no preâmbulo do seminário de Viña del Mar colocava-se que a educação médica deveria preocupar-se em criar condições para que os estudantes adquirissem conhecimentos, habilidades, atitudes e consciência ética para promover, preservar e restaurar a saúde (ORGANIZACION PANAMERICANA DE LA SALUD, s/d.).

Em sintese, as décadas de 1960 e 1970 foram prolíficas pela existência de movimentos de reforma médica: medicina preventiva, medicina integral, saúde pública, medicina comunitária, - diferentes termos que representaram diferentes movimentos de reformas de saúde e de educação médica que influenciaram a docência, a investigação e as práticas de saúde no Brasil. AROUCA (1975), estudando a medicina preventiva em sua tese de doutorado, identificou três vertentes nos departamentos de medicina preventiva: a apologética, a tecnocrática e a urítica, 
que caracterizava a posição dos referidos departamentos ante o movimento preventivista. Esse movimento de reforma que originou a criação daqueles departamentos em algumas escolas médicas nos anos 1960, foi posteriormente institucionalizado com a reforma universitária de 1968 (TEIXEIRA 1995).

A constituição e ampliação dos departamentos de medicina preventiva, medicina social ou saúde coletiva em suas distintas tendências, juntamente com a análise das condições de saúde, da organização da prática médica e em conjunto com as reorganizações da assistência médica, deram respaldo às inovações na educação médica (DONNANGELO 1983).

Outra experiência de experimentação curricular que teve lugar no Brasil, no período compreendido entre 1965-1975 foi apresentadas ao relatório EMA (Educação Médica nas Américas), em que a Universidade de São Paulo, a Universidade de Brasilia e a Universidade Federal de Minas Gerais desenvolveram propostas de mudanças curriculares, visando a preparar médicos com potencial ampliado no tratamento das necessidades de saúde no cenário comunitário (SOBRAL 1991).

Cada uma das propostas definiu de maneira particular a organização e gestão curricular como também diferentes características na abordagem comunitária. A Universidade de Brasília teve a mais criativa experiência curricular; era uma universidade recém criada e com um ideário novo sobre educação médica e saúde. A Universidade de São Paulo criou o curso experimental como uma alternativa curricular que possibilitava a introdução de novas concepções educativas, como também responder à ampliação quantitativa do alunado frente à realidade. $E$ a Faculdade de Medicina da UFMG que teve um currículo experimental por 10 anos, o qual serviu de base para as modificações que foram feitas no currículo nos anos seguintes. Segundo o autor, foi possivel observar dois efeitos relacionados aos propósitos dos novos currículos; um foi o impacto no sistema regional de saúde, que foi percebido tanto na Universidade de Brasília, como na Universidade de Minas Gerais, o qual contribuiu para o aumento da cobertura do sistema nas duas e da provisão de serviços de atenção médica e em particular com o impacto do programa de internato rural. Outro foi o impacto educativo: na UnB, onde uma parcela restrita dos formandos havia decidido praticar medicina geral em pequenas localidades e em saúde pública, porém, a preferencia dos estudantes para atendimento de primeira 
linha, tendia aumentar do início para o fim do curso. Na USP, o curso experimental contribuiu para o movimento de renovação curricular nos anos setenta e a UFMG foi um forte centro de disseminação de inovação nos âmbitos regional e nacional, porém não existem informações se os alunos modificaram sua opções de carreira em função de terem participado do curso experimental (SOBRAL 1991).

As inovações no ensino médico amparadas em medidas de política educacionais, tais como a reforma universitária de 1968 no Brasil, definiram um novo currículo mínimo para as escolas médicas. Nestas, os departamentos de Medicina preventiva, que já estavam sendo implantados desde a década de 1950, tiveram como função a realização de investigações epidemiológicas, de integração das ciências da conduta com a prática clínica num todo bio-psicossocial que se comprometia com o coletivo (DONNANGELO 1983, WESTPHAL 1992). É interessante ressaltar que a modernização da universidade brasileira ocorreu menos por pressão da rebelião estudantil do que pela descoberta de que a inovação pretendida podia ser manipulada sem ameaças à estrutura do poder vigente na instituição. $O$ governo assumiu a responsabilidade da inovação da implantação em um momento histórico em que se expurgavam os aspectos político-ideológicos, e a educação ficou enfocada como fenômeno isolado do contexto social e político (ROMANELLI 1986).

Para DONNANGELO e PEREIRA (1976), a proposta da medicina comunitária surgiu como uma estratégia de prestação de serviços à população nas sociedades em que a estrutura de serviços não era suficiente para resolver a problemática de extensão e sustentação dos serviços médicos. O ponto de referência inicial da delimitação do campo da medicina comunitária foi o fato de que a generalização do consumo médico não se efetivou igualmente em todas as sociedades capitalistas assim o objeto por excelência desse campo eram as categorias sociais excluídas do processo de medicalização.

A partir da percepção da inadequação das ações e serviços aos grupos populares que ficavam à margem dos benefícios dos cuidados de saúde, procurou-se construir serviços em função dos bolsões de pobreza, buscando a constituição de um isolamento sanitário em torno desses grupos, como também a possibilidade de manter o controle social sobre eles (MERHY s/d). Esta era proposta da medicina comunitária que tinha um caráter racionalizador e buscava uma aproximação com os serviços de 
saúde pública, para a operacionalização das medidas de promoção de saúde e prevenção de riscos e danos e a extensão de cobertura (TELXEIRA 1995).

Com a Conferência de Alma-Ata em 1978, surgiu um conjunto de princípios para nortear uma nova reforma médica, que do ponto de vista de MERHY foi mais retórica do que prática (MERHY s/d). A proposta principal da declaração era a constituição dos Cuidados Primários em Saúde a partir de uma rede de serviços de Atenção Primária de Saúde. Os conceitos básicos seriam o trabalho em comunidade, sendo a comunidade definida como uma coleção de indivíduos que se agrupariam em função de um mesmo horizonte sociocultural e que teriam como núcleo a família. A participação comunitária, que foi entendida como o processo pelo qual os indivíduos e famílias assumem a responsabilidade pela saúde e o bem-estar próprios e coletivos e desenvolvem a capacidade de contribuição para o desenvolvimento pessoal e comunitário. Com relação à saúde e serviços, foi adotada a definição de saúde da Organização Pan-Americana de Saúde, que utilizava a História Natural da Doença, perspectiva esta já extremamente criticada pela falta de compreensão da totalidade do fenômeno saúde-doença (MERHY s/d).

Paralelamente a esses acontecimentos, no Brasil iniciava-se, na segunda metade da década de 1970, um movimento de discussão de idéias reformadoras que, por meio de ações tomadas na área da saúde, gerou um processo de discussão a respeito do sistema de saúde nacional. As propostas tinham como objetivo principal a constituição de um sistema público, único, universal e descentralizado, e já apontavam problemas relacionados com a formação de recursos humanos e indicavam a necessidade de integração dos sistemas de ensino e de saúde para que as mudanças fossem efetivas (FEUERWERKER e MARSIGLIA 1996).

$\mathrm{Na}$ mesma década, com a distensão política, começaram a ser realizados encontros, promovidos por profissionais de saúde, sindicalistas e com a participação da sociedade, para a discussão e definição dos fundamentos de um sistema de saúde pública participativo e universal para o país. Foi assim que floresceu um dos mais importantes movimentos sociais no Brasil, denominado Reforma Sanitária, que deu origem às primeiras iniciativas de aplicação dos princípios que mais tarde iriam se consolidar no SUS (FLEURY 1994; FUNDAÇÃO OSWALDO CRUZ 1998). 
Na década de 1980, sob a influência da Conferência de Alma-Ata (1978) e das estratégias da OMS/OPAS, visando a "Saúde para todos no ano 2000", começaram a emergir novas metodologias e/ou estratégias de ensino em saúde, como a proposta de Integração Docente-Assistencial (IDA), lançada pelo Ministério da Educação (MEC). A IDA tinha como propósitos a articulação entre instituições de ensino e serviços de saúde para que eles promovessem a adequação de práticas profissionais às necessidades de saúde da população, bem como a produção de conhecimentos e a capacitação de recursos humanos necessários para modificar as formas de atuação dos serviços de saúde e de ensino. Nessa ocasião, o próprio MEC reconhecia que as universidades brasileiras não se constituíam em agentes de mudança, mas admitia que, se as universidades fossem inseridas na prática, poderiam ser induzidas a modificar os curriculos em função do contato direto com as necessidades de saúde da população. As experiências de IDA conseguiram produzir, somente em parte, algumas mudanças nos modelos curriculares, nos serviços de saúde integrados com as universidades e na atuação da população da área de influência desses serviços (MARSIGLIA 1995; FEUERWERKER e MARSIGLIA 1996; PAIM 1994). Em alguns casos, reproduziam no câmpus avançado o que faziam no hospital, isto é, utilizavam a prática para ensinar anamnese, exame físico, e não para discutir a ampla determinação do processo saúde-doença.

As propostas oriundas do preventivismo, da medicina comunitária, da medicina integral e da Integração Docente-Assistencial foram objeto de análises e reflexões, mas não modificaram a contradição estrutural da educação médica, ou seja, não houve modificação na prática hegemônica dos docentes na América Latina, que continuou sendo a prática médica liberal. Alguns autores consideram que, embora cada um desses movimentos tenha trazido à discussão novos conceitos importantes para questionar o modelo vigente, nenhum deles pôde reverter as tendências então instaladas (ALMEIDA 1999; RODRIGUEZ-NETO 1987). Apesar de todas essas experiências não persistirem no tempo, elas foram capazes de influenciar as propostas que vieram a seguir.

Com a promulgação da Constituição Federal Brasileira em 1988, foi instituído o Sistema Único de Saúde (SUS), que mudou o paradigma biologicista, individual e curativo vigente na saúde para um outro de determinação social. Nesse contexto, era 
mais do que pertinente repensar a formação dos profissionais inseridos no setor da saúde. A formação de recursos humanos em saúde, pela sua importância na sociedade, ultrapassou os limites da própria corporação médica e acadêmica, ganhando espaço nos meios de comunicação social. A democratização desses debates teve como marco fundamental a $8^{\text {a }}$ Conferência Nacional de Saúde (MINISTÉRIO DA SAÚDE 1986) e a Constituição Federal de 1988 (BRASIL 1988).

Quatro importantes propostas de mudança na educação médica no cenário latino-americano na década de 1990, foram estudadas por ALMEIDA (1999), em relação ao desempenho teórico-prático: a proposta UNI da Fundação Kellogg; a proposta Changing (mudança na educação e na prática médica: uma agenda para a ação ) da Organização Mundial de Saúde; a proposta Network (aprendizagem baseada em problemas em instituições de ensino orientadas para a comunidade) e a proposta Gestão de qualidade na educação médica, da Organização Pan-Americana de Saúde.

A proposta UNI, foi se delineando com base na avaliação crítica das experiências de Integração Docente-Assistencial, com o desafio de articular a universidade (não mais com as faculdades de medicina de forma isolada) com os serviços de saúde e a comunidade. Embora os modelos de serviço e os modelos pedagógicos apresentem variações nos diferentes locais onde foi implantado, os denominadores comuns da proposta UNI são a base epidemiológica, a interdisciplinaridade, o trabalho em equipe multiprofissional e o ensino-aprendizagem em serviço. Com relação à metodologia de ensino, considerou-se importante contemplar três aspectos: a diversificação dos cenários de ensino-aprendizagem, o treinamento em serviço e as experiências de aprendizagem em equipes multiprofissionais. Em todo o curso deveria predominar a experiência de aprendizagem, de interação do aluno com o meio ambiente, com a participação ativa do aluno no seu processo de conhecimento, através do método de resolução de problemas e da participação em projetos de investigação científica (FEUERWERKER e MARSIGLIA 1996). As experiências com os diferentes projetos UNI tem contribuído sobremaneira para a discussão da educação médica brasileira e segundo ALMEIDA (1999) esta é a proposta mais consistente e estruturada, pois apesar de suas debilidades, ela é a responsável pelos processos de mudança mais avançados, quando comparadas com as outras três propostas. 
A proposta Changing, surgiu em 1991, com a intenção de responder a cinco requisitos essenciais: à avaliação e melhoria da qualidade de assistência através de um atendimento integral à saúde; a utilização adequada e ética de novas tecnologias considerando-se o custo-beneficio para o paciente; a promoção de estilos de vida saudáveis em indivíduos e grupos sociais; e com relação á saúde, à busca do equilíbrio entre as expectativas dos pacientes e das sociedades e finalmente a capacitação para o trabalho em equipes intra e extra setoriais. ALMEIDA (1999), considerou que do ponto de vista teórico-conceitual e metodológico esta proposta é bastante frágil, pois não aprofunda a análise das determinações entre as relações entre educação, prática médica e sistema de saúde. A implantação e o desenvolvimento da "Changing" não chegou a desencadear processos e resultados significativos nos paises da América Latina e mesmo em outras partes do mundo, parte por falta de sustentação financeira e parte pelas suas próprias debilidades.

A proposta "Gestão de qualidade", apesar de ser fruto de uma rica e aprofundada discussão, cujas bases conceituais estavam relacionadas pela corrente de medicina social latino-americana, inaugurada por Juan César Garcia, não conseguiu se viabilizar como um processo em desenvolvimento tendo uma vida bastante efêmera (ALMEIDA, 1999).

Com relação à Network, é uma proposta datada do final da década de $70 \mathrm{e}$ início dos 80 que só alcançou expressão na América Latina nos anos 90 . Network é uma rede na qual pessoas e instituições podem ser afiliadas independentemente de ter comprometimento com a proposta. Segundo ALMEIDA (1999), apesar de limitada ao componente educacional do processo de formação, a proposta é consistente do ponto de vista teórico-conceitual. As principais características são a educação centrada no estudante, a educação baseada na comunidade e a aprendizagem baseada em problemas. Tem ainda uma expressão limitada embora crescente na América Latina, pois existem apenas iniciativas isoladas (Marilia, Londrina e Cali) de utilização da Aprendizagem Baseada em Problemas no currículo como um todo, sendo esta um dos eixos fundamentais da proposta. Como debilidades, são apontadas a centralidade da proposta na educação médica e a limitada compreensão das estruturas econômicosociais e suas relações com a prática médica (ALMEIDA 1999). 
Com relação a um importante processo de avaliação da educação médica, realizados no Brasil, deve-se destacar o trabalho feita pela Comissão Interinstitucional de Avaliação do Ensino Médico (CINAEM). Esta comissão teve início em 1991, com o objetivo central de transformar a formação médica na perspectiva de atender às demandas sociais. Contando com a participação de entidades representativas de docentes, alunos, representações sindicais e associativas, e considerando que a formação do médico não é responsabilidade exclusiva da escola médica, foi realizado um estudo multicêntrico, em três fases, que resultou num documento que apontou os quatro principais eixos de ação: (1) a metodologia de ensino; (2) docência médica profissionalizada; (3) avaliação transformadora; e (4) processo de gestão das universidades, oferecendo alternativas para que cada escola pudesse avançar nas transformações de suas respectivas realidades. Esse processo de avaliação contribuiu muito para que se estabelecessem novas diretrizes curriculares no ensino médico brasileiro (CINAEM 2000).

\section{OUTROS ATORES COLETIVOS: AS ASSOClaÇÕES E AS CONFERÉNCIAS QUE INFLUENCIARAM A EDUCAÇÃo MÉDICA}

A educação médica também foi influenciada por outros atores ao longo do século XX. Podemos citar como exemplos a Federação Pan-Americana de Faculdades de Medicina (FEPAFEM), a Associação Latino-Americana de Faculdades e Escolas de Medicina (ALAFEM) e, no Brasil, a Associação Brasileira de Educação médica (ABEM), que promoveram encontros, debates e produziram muitos artigos e documentos. Essas associações foram criadas como espaços de debates para os problemas de ensino da medicina, bem como de realização de pesquisas e de aperfeiçoamento de professores (OPAS 1994).

Alguns organismos estrangeiros tiveram, e ainda têm grande influência na educação médica no Brasil, como a Fundação Kellogg que até hoje exerce um papel ativo na formulação de políticas educacionais na América Latina, como também o fez no passado a Rockefeller Foundation (FEUERWERKER 1998). Outras instituições que patrocinam pesquisas em educação médica nos Estados Unidos, como a Macy 
Conference on Clinical Education and the Doctor of Tomorrow, pela fundação Robert Wood Johnson - Commission on Medical Education e pela PEW Health Profession Commission - Practicioners for 2005, também acabaram influenciando direta ou indiretamente os caminhos da educação médica em outros países MENNIN e KRACKOV 1998).

A OPAS também teve e ainda continua tendo um papel relevante na discussãc e nas ações de formação de recursos humanos em saúde, tanto na América Latina como na América do Norte (FEUERWERKER 1998; MENNIN e KRACKOV 1998).

As Conferências Internacionais como as de Edimburgo, em 1988 e 1993, e a de Havana, em 1991, influenciaram as reformas de educação médica, trazendo diversas propostas de avaliação e mudanças nas escolas médicas (FERREIRA 1994; ALMEIDA 1999). Em particular, para a Conferência Mundial de Educação médica realizada em Edimburgo em 1988, a Associação Brasileira de Medicina preparou relatórios regionais, levando os seguintes itens para debate: a prioridade na redefinição dos programas de formação médica, tendo em conta o progresso científico e tecnológico, as mudanças sociais e institucionais, bem como as necessidades de saúde da população em relação à assistência à saúde. Sugeriu também que os programas se preocupassem em promover mudanças curriculares, enfatizando a formação para o trabalho em atenção primária de saúde.

Os relatórios dessa mesma conferência apontaram a necessidade de a educação médica desenvolver-se para relacionar as necessidades de saúde da população, o perfil de morbimortalidade e o perfil profissional com o conteúdo e a metodologia de ensino. Com relação às estratégias educacionais, destacaram a necessidade de as escolas se posicionarem ante os novos contextos da sociedade e dos sistemas de saúde em transformação, definindo prioridades educacionais através das demandas dos serviços. Consideraram como imperativa a mudança da metodologia de ensino-aprendizagem e a importância do compromisso da escola médica com a assistência à saúde. Com relação à aprendizagem, considerou-se que a maneira mais eficiente e duradoura de adquirir conhecimentos, habilidades ou atitudes é exercitarse: aprender fazendo é mais eficiente do que receber informações. As escolas deveriam assegurar oportunidades de aprendizagem ativa, que permitissem experiências pessoais significativas e mobilizadoras (FEUERWERKER 1998). 
A II Conferência Mundial de Educação médica, também realizada em Edimburgo em 1993 (BATISTA e SILVA 1998), representou um avanço em relação à anterior, pela preocupação demonstrada quanto ao contexto social. Desta reunião surgiram recomendações que podem ser resumidas em cinco itens:

1. A prática e política de saúde: a importância da conjunção entre a educação e o cenário da prática médica, considerando a transição epidemiológica, a necessidade de equilíbrio na formação de generalistas e especialistas, e a reformulação dos sistemas de saúde.

2. A resposta educacional: a ênfase na necessidade de aprimoramento docente para a melhoria da educação médica, o engajamento do estudante no planejamento e no ensino, a utilização de diferentes estratégias e métodos de ensino, bem como a importância da base ética na educação.

3. O continuum da educação médica através da educação médica continuada.

4. As parcerias na aprendizagem: com o objetivo do trabalho de equipe e educação multiprofissional, da comunicação com o público e da participação das comunidades na educação médica e no processo decisório em saúde.

5. Os cenários para a aprendizagem, ambientadas no mundo real e o compromisso com a educação baseada na comunidade.

Pode-se observar, ao longo dos anos, houve, e ainda há, iniciativas de articulação de grupos, de lideranças e de outros atores sociais comprometidos com as transformações do sistema de saúde e das instituições de ensino na discussão da educação médica. Segundo PAIM (1994), esses fatores podem representar avanços positivos na modificação do panorama que envolve a formação de recursos humanos para a saúde e na adequação às necessidades de saúde da população, ainda mais no presente momento com a aprovação de novas diretrizes paras as escolas brasileiras.

\section{AS NOVAS DIRETRIZES E BASES DA REFORMA CURRICULAR NO BRASIL}

Buscando situar o atual movimento de transformação da educação médica no contexto da redemocratização brasileira, AGUIAR (2001), coloca que o processo de definição de diretrizes curriculares foi um exercício de democracia, que levou em 
consideração a insatisfação de usuários do sistema de saúde através dos movimentos sociais que encontraram eco nas lideranças acadêmicas.

A organização de vários fóruns de discussão que congregaram alunos, docentes e gestores, capitaneados pela Associação Brasileira de Educação Médica (ABEM), a Comissão Interistitucional Nacional de Avaliação da Educação Médica (CINAEM), e a rede UNIIDA, acumulou credibilidade e adquiriu legitimidade perante a sociedade e o governo federal. Tal fato levou o Ministério da Educação a assumir o compromisso de encaminhar ao Conselho Nacional de Educação as diretrizes curriculares para a educação médica, que foram consensuadas pela comunidade acadêmica da área, e que colocam na pauta o estabelecimento de um novo pacto entre escolas médica e sociedade (AGUIAR 2001).

No bojo deste processo de discussão de novas diretrizes para o currículo médico, surgiu a oportunidade de transformar em lei, alguns dos aspectos fundamentais que vinham há muito sendo discutidos. O Conselho Nacional de Educação, através da Câmara de Educação Superior do Ministério da Educação, aprovou em outubro de 2001 as Diretrizes Curriculares Nacionais do Curso de Graduação em Medicina, que mostraremos na integra:

\section{DIRETRIZES CURRICULARES NACIONAIS DO CURSO DE GRADUAÇÃO EM MEDICINA:}

\section{PERFIL DO FORMANDO EGRESSO/PROFISSIONAL}

Médico, com formação generalista, humanista, crítica e reflexiva. Capacitado a atuar, pautado em principios éticos, no processo de saúde-doença em seus diferentes niveis de atenção, com ações de promoção, prevenção, recuperação e reabilitação à saúde, na perspectiva da integralidade da assistência, com senso de responsabilidade social e compromisso com a cidadania, como promotor da saúde integral do ser humano.

\section{COMPETÊNCIAS E HABILIDADES}

\section{Competências Gerais:}

- Atenção à saúde: os profissionais de saúde, dentro de seu âmbito profissional, devem estar aptos a desenvolver ações de prevenção, 
promoção, proteção e reabilitação da saúde, tanto em nivel individual quanto coletivo. Cada profissional deve assegurar que sua prática seja realizada de forma integrada e continua com as demais instâncias do sistema de saúde. Os profissionais devem realizar seus serviços dentro dos mais altos padrões de qualidade e dos princípios da ética bioética, tendo em conta que a responsabilidade da atenção à saúde não se encerra com o ato técnico, mas sim com a resolução do problema de saúde, tanto a nivel individual como coletivo;

- Tomada de decisões: o trabalho dos profissionais de saúde deve estar fundamentado na capacidade de tomar decisões visando o uso apropriado, eficácia e custo-efetividade, da força de trabalho, de medicamentos, de equipamentos, de procedimentos e de práticas. Para este fim, os mesmos devem possuir habilidades para avaliar, sistematizar e decidir a conduta mais apropriada;

- Comunicação: os profissionais de saúde devem ser acessiveis e devem manter a confidencialidade das informações a eles confiadas, na interação com outros profissionais de saúde e o público em geral. A comunicação envolve comunicação verbal, não-verbal e habilidades de escrita e leitura; o domínio de, pelo menos, uma língua estrangeira e de tecnologias de comunicação e informação;

- Liderança: no trabalho em equipe multiprofissional, os profissionais de saúde deverão estar aptos a assumir posições de liderança, sempre tendo em vista o bem estar da comunidade. A liderança envolve compromisso, responsabilidade, empatia, habilidade para tomada de decisões, comunicação e gerenciamento de forma efetiva e eficaz;

- Administração e gerenciamento: os profissionais devem estar aptos a fazer o gerenciamento e administração tanto da força de trabalho, dos recursos fisicos e materiais e de informação, da mesma forma que devem estar aptos a ser gestores, empregadores ou lideranças na equipe de saúde;

- Educação permanente: os profissionais devem ser capazes de aprender continuamente, tanto na sua formação quanto na sua prática. Desta forma, os profissionais de saúde devem aprender a aprender e ter responsabilidade e compromisso com a educação e o treinamento/estágios das futuras gerações de profissionais, não apenas transmitindo conhecimentos, mas proporcionando condições para que haja beneficio mútuo entre os futuros profissionais e os profissionais dos serviços.

\section{Conhecimento, Competências e Habilidades Especificas:}

- Promover estilos de vida saudáveis, conciliando as neccssidades tanto dos seus clientes/pacientes quanto às de sua comunidade, atuando como agente de transformação social;

- Atuar nos diferentes niveis de atendimento à saúde, com ênfase nos atendimentos primário e secundário;

- Comunicar-se adequadamente com os colegas de trabalho, os pacientes e seus familiares;

- Informar e educar seus pacientes, familiares e comunidade em relação à 
promoção da saúde, prevenção, tratamento e reabilitação das doenças, usando técnicas apropriadas de comunicação;

- Realizar com proficiência a anamnese e a conseqüente construção da história clinica, bem como dominar a arte e a técnica do exame fisico;

- Dominar os conhecimentos cientificos básicos da natureza biopsicossocioambiental subjacentes à prática médica e ter raciocínio crítico na interpretação dos dados, na identificação da natureza dos problemas da prática médica e na sua resolução;

- Diagnosticar e tratar corretamente as principais doenças do ser humano em todas as fases do ciclo biológico, tendo como critérios a prevalência e o potencial mórbido das doenças, bem como a eficácia da ação médica;

- Reconhecer suas limitações e encaminhar, adequadamente, pacientes portadores de problemas que fujam ao alcance da sua formação geral;

- Otimizar o uso dos recursos propedêuticos, valorizando o método clínico em todos os seus aspectos;

- Exercer a medicina utilizando procedimentos diagnósticos e terapêuticos com base em evidencias científicas;

- Utilizar adequadamente recursos semiológicos e terapêuticos, validados cientificamente, contemporâneos, hierarquizados para atenção integral à saúde, no primeiro, segundo e terceiro niveis de atenção;

- Reconhecer a saúde como direito e atuar de forma a garantir a integralidade da assistência entendida como conjunto articulado e contínuo de ações e serviços preventivos e curativos, individuais e coletivos, exigidos para cada caso em todos os niveis de complexidade do sistema;

- Atuar na proteção e na promoção da saúde e na prevenção de doenças, bem como no tratamento e reabilitação dos problemas de saúde $e$ acompanhamento do processo de morte;

- Realizar procedimentos clínicos e cirúrgicos indispensáveis para o atendimento ambulatorial e para o atendimento inicial das urgências e emergências em todas as fases do ciclo biológico;

- Conhecer os principios da metodologia cientifica, possibilitando-lhe a leitura crítica de artigos técnico-cientificos e a participação na produção de conhecimentos;

- Lidar criticamente com a dinâmica do mercado de trabalho e com as políticas de saúde;

- Atuar no sistema hierarquizado de saude, obedecendo aos principios lécnicos e éticos de referência e contra-referência;

- Cuidar da própria saúde fisica e mental e buscar seu bem-estar como cidadão e como médico;

- Considerar a relação custo-beneficio nas decisões médicas, levando em conta as reais necessidades da população;

- Ter visão do papel social do médico e disposição para atuar em atividades de política e de planejamento em saúde;

- Atuar em equipe multiprofissional;

- Manter-se atualizado com a legislação pertinente á saúde. 
Com base nestas competências, a formação do médico deverá contemplar o sistema de saúde vigente no país, a atenção integral da saúde num sistema regionalizado e hierarquizado de referência e contra-referência e o trabalho em equipe

\section{CONTEÚDOS CURRICULARES}

Os conteúdos essenciais do curso de graduação em Medicina devem guardar estreita relação com as necessidades de saúde mais freqüentes referidas pela comunidade e identificadas pelo setor saúde. Devem contemplar:

- Conhecimento das bases moleculares e celulares dos processos normais e alterados, da estrutura e função dos tecidos, órgãos, sistemas e aparelhos, aplicados aos problemas de sua prática e na forma como o médico o utiliza;

- Compreensão dos determinantes sociais, culturais, comportamentais, psicológicos, ecológicos, éticos e legais, nos niveis individual e coletivo, do processo saúde-doença;

- Abordagem do processo saúde-doença do individuo e da população, em seus múltiplos aspectos de determinação, ocorrência e intervenção;

- Compreensão e dominio da propedêutica médica - capacidade de realizar história clínica, exame fisico, conhecimento fisiopatológico dos sinais e sintomas; capacidade reflexiva e compreensão ética, psicológica e humanistica da relação médico-paciente;

- Diagnóstico, prognóstico e conduta terapêutica nas doenças que acometem o ser humano em todas as fases do ciclo biológico, considerando-se os critérios de prevalência, letalidade, potencial de prevenção e importância pedagógica;

- Promoção da saúde e compreensão dos processos fisiológicos dos seres humanos: gestação, nascimento, crescimento e desenvolvimento, envelhecimento, atividades fisicas, desportivas e as relacionadas ao meio social e ambiental.

\section{ORGANIZACÁO DO CURSO}

O Curso de Graduação em Medicina deve ter um projeto pedagógico,. construido coletivamente, centrado no aluno como sujeito da aprendizagem e apoiado no professor como facilitador e mediador do processo ensino-aprendizagem. Este projeto pedagógico deverá buscar a formação integral e adequada do estudante através de urna articulação entre o ensino, a pesquisa e a extensão assistência.

As Diretrizes Curriculares e o Projeto Pedagógico devem orientar o Currículo do Curso de Graduação em Medicina para um perfil acadêmico e profissional do egresso. Este curriculo deverá contribuir, também, para a compreensão, interpretação, preservação, reforço, fomento e difusão das culturas nacionais e regionais, internacionais e históricas, em um contexto de pluralismo e diversidade cultural.

O Curriculo do Curso de Graduação em Medicina poderá incluir aspectos complementares de perfil, habilidades, competências e conteúdos, de formação, e 
considerar a inserção institucional do curso, a flexibilidade individual de estudos e os requerimentos, demandas e expectativas de desenvolvimento do setor saúde na região.

A organização do Curso de Graduação em Medicina deverá ser definida pelo respectivo colegiado do curso, que indicará a modalidade seriada anual, seriada semestral, sistema de créditos ou modular.

A estrutura do Curso de Graduação em Medicina deverá;

- ter como eixo do desenvolvimento curricular as necessidades de saúde dos individuos e das populações referidas pelo usuário e identificadas pelo setor saúde;

- utilizar metodologias que privilegiem a participação ativa do aluno na construção do conhecimento e a integração entre os conteúdos, além de estimular a interação entre o ensino, a pesquisa e a extensão/assistência;

- incluir dimensões éticas e humanísticas, desenvolvendo no aluno atitudes e valores orientados para a cidadania,

- promover a integração e a interdisciplinaridade em coerência com o eixo de desenvolvimento curricular, buscando integrar as dimensões biológicas, psicológicas, sociais e ambientais;

- inserir o aluno precocemente em atividades práticas relevantes para a sua futura vida profissional;

- utilizar diferentes cenários de ensino-aprendizagem permitindo ao aluno conhecer e vivenciar situações variadas de vida, da organização da prática e do trabalho em equipe multiprofissional;

- propiciar a interação ativa do aluno com usuários e profissionais de saúde desde o inicio de sua formação, proporcionando ao aluno lidar com problemas reais, assumindo responsabilidades crescentes como agente prestador de cuidados e atenção, compativeis com seu grau de autonomia, que se consolida na graduação com o internato;

- através da integração ensino-serviço vincular a formação médicoacadêmica às necessidades sociais da saúde, com ênfase no SUS.

\section{ESTAGIOS E ATIVIDADES COMPLEMENTARES}

- Estágios

A formação médica incluirá, como etapa integrante da graduação, estágio curricular obrigatório de treinamento em serviço, em regime de internato, em serviços próprios ou conveniados, e sob supervisão direta dos docentes da própria Escola Faculdade, com duração mínima de 2700 horas.

$O$ estágio curricular obrigatório de treinamento $\mathrm{em}$ serviço incluirá necessariamente aspectos essenciais nas áreas de Clínica Médica, Cirurgia, Ginecologia-Obstetricia, Pediatria e Saúde Coletiva, devendo incluir atividades no primeiro, segundo e terceiro niveis de atenção em cada área.

- Colegiado do Curso de Medicina poderá autorizar, no máximo de 25\% da carga horária total estabelecida para este estágio, a realização de treinamento supervisionado fora da unidade federativa, preferencialmente nos serviços do Sistema Único de Saúde, bem como em Instituição conveniada que mantenha programas de Residencia credenciados pela Comissão Nacional de Re lência 
Médica elou outros programas de pós-graduação.

- Atividades Complementares

As atividades complementares deverão ser incrementadas durante todo o Curso de Graduação em Medicina e as instituições de Ensino Superior deverão criar mecanismos de aproveitamento de conhecimentos, adquiridos pelo estudante, através de estudos e práticas independentes presenciais eiou à distância.

Podem ser reconhecidos:

- Monitorias e Estágios,

- Programas de Iniciação Cientifica;

- Programas de Extensão;

- Estudos Complementares;

- Cursos realizados em outras áreas afins.

\section{ACOMPANHAMENTO E AVALIACÃO}

A implantação e desenvolvimento das diretrizes curriculares de medicina devem ser acompanhados e permanentemente avaliados, a fim de permitir os ajustes que se fizerem necessários a sua contextualização e aperfeiçoamento.

As avaliações somativa e formativa do aluno deverão basear-se nas competencias, habilidades e conteúdos curriculares.

O Curso de Graduação em Medicina deverá utilizar metodologias e critérios para acompanhamento e avaliação do processo ensino-aprendizagem e do próprio curso, em consonância com o sistema de avaliação definido pela ES a qual pertence.

Nesse novo contexto, aumentou a possibilidade de transformar a educação médica para uma maior flexibilização curricular e adoção de novas práticas educativas. Aumentou também a preocupação com a formação de um médico voltado para as necessidades da sociedade na qual ele desenvolverá seu trabalho, buscando preparar um profissional mais humano e competente ética e tecnicamente. 
Capítulo 1

Educação Médica e reforma curricular 


\section{O SIGNIFICAdO de CURRÍCULO E AS REFORMAS CURRICULARES NA EDUCAÇÃO} MÉDICA

Quando se fala em mudança na escola médica, usualmente a primeira iniciativa é promover uma reforma curricular que se limite apenas a um ajuste de posicionamento disciplinar e de carga horária. A experiência acumulada, entretanto, tem demonstrado a insuficiência dessa prática, ou seja, quando se promovem modificações apenas na grade curricular (OPAS 1994).

A idéia de currículo que está presente em muitas escolas de medicina é a de que a formação profissional se dá pelo acúmulo de conhecimentos científicos justapostos, muitas vezes divididos em dois ciclos, um teórico e outro profissionalizante. Tal fato acontece, apesar de todo avanço teórico-metodológico que vem ocorrendo no tratamento das questões de educação e ensino no Brasil e no mundo. O currículo assim idealizado tem por base os usos tradicionais de educação, em que a teoria vem antes da prática e os conhecimentos estão divididos, fragmentados e ensinados por especialistas que dominam os conteúdos e por isso os transmitem aos alunos de forma expositiva (BERBEL 1994).

Os currículos ligados à educação tradicional têm seus conteúdos narrados a educandos passivos, meros ouvintes das importantes mensagens do educador. Esses conteúdos são produtos da visão do educador, que enfatiza certos aspectos e omite outros, dando a impressão de que não há mais nada a acrescentar ou discutir. $\mathrm{A}$ comunicação é unilateral e praticamente não há diálogo. A relação entre educador e educando é de doação, em que o primeiro doa generosamente seu conhecimento a um recebedor que deveria agradecer, e não discutir o que recebeu. A autoridade funcional do professor é confundida com a autoridade do saber; o educando é aquele que nada sabe e é condicionado a seguir as ações prescritas. Hegemonicamente, esta é a pedagogia utilizada na educação médica, especialmente nos primeiros anos do curso médico das escolas tradicionais, no chamado ciclo básico.

O pressuposto é que o domínio dos últimos avanços técnicos e científicos adquiridos através da transmissão de conhecimentos conduza necessária e 
suficientemente à boa prática médica (MACHADO, CALDAS e BERTONCELLO 1997).

Aqui se faz necessário discutir as diferentes conceituações de curriculo segundo diferentes autores e diferentes perspectivas.

LOUZADA e ANGULO (1999) e TOMAZ (2001) tomam por base um trabalho realizado por George Posner em 1995 em que o autor sintetizou os seis conceitos mais comuns de currículo na literatura estudada: (1) Seqüência e abrangència, em que a descrição do currículo é uma lista de objetivos de aprendizagem dos diferentes anos (seqüência) e agrupados de acordo com um tópico ou tema (abrangência); (2) Programa, em que se realiza todo o plano do curso, incluindo a justificativa, os tópicos compreendidos, os recursos utilizados e a avaliação realizada; (3) Conteúdo do curso em que se listam os conteúdos que serão transmitidos durante o curso; (4) Livros-textos, que seriam os materiais instrutivos utilizados no curso; (5) Cursos ou planos de estudo, que seriam os cursos que o estudante deve completar ou percorrer; (6) Experiências planejadas, que seriam todas as experiências que o estudante têm e tenham sido planejadas pela escola, como as acadêmicas, as esportivas, as sociais, as artísticas e as extracurriculares.

BATISTA e SILVA (1997) também levantaram diferentes conceituaçð̃es de curriculo entre diversos autores: 1) uma construção social elaborada no cotidiano das relações institucionais, que pode ser analisado como uma função social, refletida na relação escola-sociedade; 2) um projeto ou plano educativo; 3) um campo prático que permite analisar a realidade dos processos educativos, não se restringindo aos processos pedagógicos; 4) espaço de articulação entre teoria e prática ou objeto de estudo e investigação. Pode-se falar de currículo ainda como uma série estruturada de resultados desejados de aprendizagem.

DEMO (1995) distingue dois aspectos extremamente importantes em relação ao conceito de curriculo: o currículo intensivo, que é concebido e praticado como estratégia de construção de conhecimento e o currículo extensivo, em que o professor apenas ensina a um aluno que apenas aprende. Nesse, a dimensão da aprendizagem é somente definida pelo repasse do professor e o aluno sabe somente o que the foi transmitido, ou seja, transmitir é a medida do saber e a aula copiada é a didática essencial. O autor toma como exemplo determinado curso em que existe 20, 30 ou até 
mais diferentes disciplinas com o mesmo número correspondente de professores, cabendo ao aluno absorver enorme quantidade de informações repassadas. A avaliação se reduz a um teste ou prova que é tão-somente a façanha de repetir a cópia, ou seja, devolver exatamente o que lhe foi ensinado.

O currículo intensivo busca outra didática, que é a construção do conhecimento, e o professor tem o papel de orientador do processo construtivo, fazendo o aluno trabalhar com autonomia crescente. No lugar de matérias utilizam-se temas de pesquisa; do conhecimento já existente, e parte-se para o aprofundamento permanente da temática, até chegar a um novo conhecimento, através de elaboração própria. A obtenção de uma visão geral da temática se dá pelo aprofundamento do conhecimento, e não pela acumulação de aulas expositivas (DEMO 1995).

Para MOREIRA e SILVA (1999), currículo é um artefato social e cultural, não é um elemento neutro e inocente de transmissão desinteressada do conhecimento social. O currículo implica relações de poder, pois transmite visões sociais particulares e interessadas, tem uma história vinculada a formas específicas de organização da sociedade.

BERBEL (1994), por exemplo, considera que a realidade social deveria ser o ponto de partida e de chegada das transformações curriculares, assim como o contexto socioeconômico, político e cultural do país e da comunidade mais próxima. Ou seja, para a autora, o currículo precisa ter por referência a realidade social e o compromisso político claramente assumido para com a sociedade a que serve.

Observa-se na literatura a existência de uma grande diversidade de conceitos de currículo. Para uns é uma área meramente técnica, relativa a procedimentos, estratégias e métodos; para outros deve-se articular o currículo com a teoria do conhecimento que lhe dá embasamento e outros ainda com a realidade e o contexto socio-econômico, político e cultural.

Não se pode perder de vista as relações de poder que permeiam o currículo, o envolvimento com a realidade e o compromisso político para com a sociedade a que serve 


\section{O PROCESSO EDUCATIVO E A GERAÇÃO dE CONHECIMENTO}

A dimensão fundamental do processo educativo consiste no ato de conhecer (GILES 1983). Entender e explicar como se gera e se acumula conhecimento é um desafio que perpassa a humanidade desde seus primórdios. Muitos filósofos e epistemólogos ao longo da história buscaram explicar o processo de conhecimentc através de diferentes teorias. Desde os primeiros pensadores gregos inaugurou-se uma rivalidade entre os que acreditavam que o conhecimento é subjetivo e adquirido através da experiência (empirismo) e aqueles que viam o conhecimento como um processo eminentemente intelectual só possível de ser adquirido pela razão pura (racionalismo) (LOUZADA e ANGULO 1999).

A oposição entre a razão e a experiência como meios de adquirir conhecimento originou duas escolas antagônicas, uma negando a validade da outra. Os adeptos da escola racionalista afirmavam que o verdadeiro conhecimento era resultado do raciocínio dedutivo. Para os seguidores da escola empirista, o verdadeiro conhecimento se dá como resultado da experiência dos sentidos (LOUZADA e ANGULO 1999).

A valorização da razão como critério último da verdade formou as bases das diversas teorias do conhecimento a partir de Descartes, e influenciando todo o pensamento científico desde seu surgimento no século XVII, atravessando os séculos e perdura até os dias de hoje (GILES 1983).

$\mathrm{Na}$ perspectiva cartesiana, o processo de conhecimento racional implicava uma série de operações de decomposição da coisa a conhecer com a finalidade de reduzi-la às suas partes mais simples de uma maneira mecanicista, através de um rigoroso método de procedimento. Havia uma etapa inicial de fragmentação do objeto do conhecimento, daí a disjunção entre análise e síntese. A análise, base do racionalismo cientifico, assumiu a função de superar as formas intuitivas de conhecimento chamadas de pré-cientificas, baseadas no empirismo (ALMEIDA $\mathrm{F}^{\circ}$ 1997)

A revolução cartesiana causou um forte impacto no pensamento científico na era moderna, e obviamente também na medicina ocidental, na prática médica e na maneira de ensinar medicina. A rigorosa divisão entre corpo e mente pretendida por 
Descartes levou os médicos a se concentrarem mais na máquina corporal e a negligenciarem os aspectos psicológicos, sociais e ambientais da doença. Antes dele, a maioria dos médicos atentava para a interação do corpo e da alma e tratava seus pacientes como um todo no contexto de seu ambiente social e espiritual (CAPRA 1982).

Nos séculos XVII e XIX, as demandas ocasionadas pela Revolução Industrial e a emergência do modo de produção capitalista determinaram um aprofundamento dos processos de produção do conhecimento sobre as partes, o que resultou numa maior fragmentação do conhecimento científico. Dessa estratégia históricainstitucional da ciência baseada na fragmentação e na especialização surgiu a disciplinaridade, e com as subdivisões internas nos próprios campos disciplinares e a criação de novas disciplinas científicas acabou se estruturando um novo sistema de ensino. Disciplina passou a ser sinônimo de matéria ensinada, em um determinado ramo do conhecimento, algo equivalente a principios, regras e métodos característicos de uma ciência particular (ALMEIDA Fo 1997).

Para MORIN (2001), os desenvolvimentos disciplinares da ciência não trouxeram somente as vantagens da divisão de trabalho, mas fundamentalmente os inconvenientes da superespecialização, do confinamento, não trouxeram apenas a elucidação, mas também a ignorância e a cegueira. Os saberes separados em disciplinas tornam impossivel o entendimento da realidade como um todo e dos problemas que são cada vez mais complexos. Uma inteligência incapaz de perceber o contexto e o complexo planetário fica cega, inconsciente e irresponsável, de modo que quanto mais multidimensional o problema, maior a incapacidade de pensar.

Para DEMO (1995), a sociedade moderna exige um cidadão capaz de pensar e enfrentar novos desafios, avaliar os contextos sócio-históricos, filtrar as informações, manter-se permanentemente em processo de formação - responsabilidades inalienáveis de quem procura ser sujeito de sua própria história.

MORIN (2001) sugere que para modificar a fragmentação que anula o complexo e oculta os problemas principais é necessário remediar a desunião entre pensamento científico e pensamento humanista. Para ele é preciso reformar o pensamento para poder reformar o ensino, que deveria retomar suas duas grandes finalidades: promover uma cabeça bem-feita, em lugar de uma cabeça bem cheia, e 
ensinar a condição humana, ensinar a enfrentar a incerteza e aprender a se tornar cidadão. Este seria o papel fundamental da educação. Convencido da necessidade da reforma do pensamento, e portanto da reforma do ensino, o autor pretende com a reforma do pensamento educar os educadores de modo mais sistêmico, gerar intelectuais polivalentes e abertos, capazes de articular suas disciplinas e investirem em reformas curriculares mais amplas que religuem natureza e cultura, homem e cosmo, e edifiquem uma aprendizagem cidadã.

\section{O PROCESSO DE CONHECIMENTO E AS ABORDAGENS EDUCATIVAS}

O conhecimento humano pode ser explicado diversamente em sua gênese e desenvolvimento segundo os diferentes referenciais, o que vai condicionar distintos conceitos de ser humano, mundo, cultura, sociedade e educação. As teorias do conhecimento podem ser consideradas, apesar de muitas variações, de acordo com três características: o primado do sujeito, o primado do objeto e o da interação entre ambos (MIZUKAMI 1986). Toda teoria educacional pressupõe uma teoria do conhecimento que lhe dá embasamento e nem sempre é explicitada (GILES 1983).

A abordagem tradicional de transmissão de conhecimentos não se fundamenta implícita ou explicitamente em teorias empiricamente validadas, dado que ela inclui tendências e manifestações diferentes entre os vários autores. A característica comum é a capacidade de armazenar informações sobre o mundo, das mais simples às mais complexas. Usualmente decompõe-se a realidade para simplificá-la, num processo de análise em que predomina um ensino eminentemente dedutivo. Nessa abordagem, a escola tem uma missão catequética e unificadora; e é o local da apropriação do conhecimento, por meio da transmissão de conteúdos e confrontação com modelos e demonstrações. Os programas são rígidos e coercitivos; os exames seletivos são revestidos de um caráter sacramental. O diploma é o princípio organizador e a consagração de todo um ciclo de estudos. O método de recitação e as espécies de conteúdo ensinado derivam de uma concepção estática do conhecimento. Nessa concepção, o conhecimento provém essencialmente do meio e, dessa forma, é transmitido ao indivíduo na escola. A ênfase não é colocada no educando, mas na intervenção do professor, para que a aquisição do patrimônio cultural seja garantida. 
$\mathrm{O}$ individuo é um ser passivo, um receptáculo de conhecimentos escolhidos e elaborados por outros, para que ele deles se aproprie (MIZUKAMI 1986).

A pedagogia tradicional se consolida no momento que uma nova classe, a burguesia, conquista o poder, após a Revolução Francesa e a Declaração dos Direitos do Homem. No início do século XIX, para superar a situação de opressão do "antigo regime" e ascender a um tipo de sociedade fundada em um contrato social de liberdade entre os individuos, era necessário vencer a barreira da ignorância. Os sistemas nacionais de ensino se constituíram inspirados no princípio de que a educação é direito de todos e dever do Estado. Foi para que fosse possível transformar súditos em cidadãos, isto é, em indivíduos livres, porque esclarecidos, que surgiu a escola. Ela aparece como um antídoto à ignorância e tem o papel de difundir a instrução e os conhecimentos acumulados pela humanidade. Ë uma agência que se organiza em torno do professor, que transmite gradativamente o acervo cultural aos alunos, cabendo a estes assimilar os conhecimentos que lhes são transmitidos. (SAVIANI 1987).

No final do século XIX e princípio do século XX, com base nas discussões sobre o que deveria ser a democracia, começou-se questionar o papel passivo dos alunos e seu isolamento da vida cotidiana. Começou-se a reclamar a importância da experiência e da vivência como fonte de aprendizagem. Para poder permitir experiências de aprendizagem era necessário criar situações semelhantes à que as pessoas tinham na sua vida cotidiana Nesta perspectiva, o empirismo e o racionalismo estão presentes para estimular simultaneamente as impressões dos sentidos e os processos mentais (LOUZADA e ANGULO 1999).

As criticas à pedagogia tradicional deram origem a outra teoria da educação, que talvez pudesse corrigir as distorções de acesso e equalização social. Assim tomou corpo outro movimento de reforma, denominado de Escola Nova. Tal movimento teve como ponto de partida as críticas à escola tradicional, deslocando-se o eixo da questão pedagógica, do intelecto para o sentimento, do aspecto lógico para o psicológico, dos conteúdos cognitivos para os métodos ou processos pedagógicos; do professor para o aluno, do esforço para o interesse. É uma teoria pedagógica que se caracteriza por defender que o mais importante não é aprender, mas aprender a aprender. O papel do professor é de um facilitador, estimulador e orientador da aprendizagem cuja 
iniciativa principal deve caber aos próprios alunos. Para tanto, a aprendizagem seria decorrência espontânea de um ambiente estimulante, dotado de diferentes materiais didáticos e da relação que se estabelece entre o aluno e o professor. Cada professor trabalha com um pequeno grupo de alunos, em que são priorizadas as relações interpessoais, que são a essência da atividade educativa. Nessa tendência educacional, modifica-se a escola, que tem um ar alegre e movimentado, mudando, portanto, o aspecto sombrio das escolas tradicionais (SAVIANI 1987).

A Escola Nova tem como representantes Dewey, Montessori, Decroly e Piaget e, no nosso meio, Anísio Teixeira. Autores como Dewey e Mannheim vêem na educação um fator de dinamização de estruturas, por meio do ato inovador do indivíduo. No processo educacional, o individuo é habilitado a atuar no contexto societário em que vive, não simplesmente reproduzindo as experiências anteriores transmitidas pelas gerações adultas, mas recriando-as, através de sua análise e avaliação crítica, para que possa reorganizar seu comportamento e contribuir para a reestruturação e reorganização da sociedade moderna. Para Dewey, o ato educacional consiste em dar aos indivíduos os subsídios necessários para que essa reorganização de experiências vividas se dê em linhas mais ou menos ordenadas e sistematizadas. Para que isso se efetive, o meio em que se dá o processo educacional tem de ser organizado e reestruturado, a fim de que haja uma seqüência adequada de experiências que possam ser avaliadas de forma sistemática. $\mathrm{O}$ meio pelo qual isso se daria é a escola, que deve assumir as características de uma pequena comunidade democrática. A vivência democrática na escola fortaleceria na criança e no futuro adulto as regras do jogo democrático, com o que seria possível reorganizar ou reestruturar os desvios econômicos, políticos ou ideológicos da sociedade (FREITAG 1980).

A filosofia tradicional que enfatizava que o conhecimento ou se gerava através do raciocínio (racionalismo), com estratégias educativas eminentemente acadêmicas e intelectuais, ou se gerava através dos sentidos (empirismo), com estratégias exageradamente vocacionais e técnicas, começou a ser questionada. John Dewey questionou os enfoques tradicionais que viam a realidade como algo externo e separado do individuo, e enfatizavam de forma excludente ou os processos mentais ou 
os processos sensoriais, sem que houvesse a interação de ambos (LOUZADA e ANGULO 1999).

$\mathrm{Na}$ visão de Dewey, não há aprendizagem genuína em processos divorciados da experiência, em que se memorizam os fatos sem perceber os relacionamentos, como também não há espaço para a aprendizagem passiva. A filosofia de Dewey rejeita o arcabouço inteiro que fundamentava o sistema educacional clássics (MAMEDE e PENAFORTE 2001).

A busca das nascentes filosóficas que vão originar a Aprendizagem Baseada em Problemas que apresentaremos a seguir é fundamentada principalmente na teoria do conhecimento do filósofo americano John Dewey (PENAFORTE 2001).

\section{Propostas metodológicas inOVAdoras Para A EdUCAÇÃo MÉdica}

A Aprendizagem Baseada em Problemas (ABP), ou Problem-Based Learning (PBL), firmou-se como uma das mais importantes inovações na educação médica e de profissionais de saúde nas últimas décadas. É uma metodologia de ensinoaprendizagem inicialmente utilizada na Universidade McMaster, em Hamilton, Ontário, Canadá, no final da década de 1960, disseminando-se ao longo do tempo para mais de sessenta universidades no mundo (KOMATSU, ZANOLLI E LIMA 1998). Outras iniciativas pioneiras podem ser citadas, como a da Universidade de Maastrich, na Holanda, a de Newcastle, na Austrália, e da Universidade do Novo México e da Escola de Medicina de Harvard, nos Estados Unidos. Atualmente várias escolas no mundo desenvolveram ou estão desenvolvendo currículos baseados em problemas em cursos, curriculos altemativos ou no currículo propriamente dito. Alguns incluem a combinação da $\mathrm{ABP}$ como uma concessão aos professores não convencidos do valor da $A B P$ (BARROWS 1996)

Essa metodologia originou-se fundamentada pela concepção da escola ativa, de Dewey e Kilpatrick, (GADOTTI 1995), que tem o indivíduo como centro das atenções para seu desenvolvimento, numa proposta em que a construção do conhecimento é realizada pelo próprio aluno. Foi fortemente influenciada pela psicologia cognitivista, iniciada por Piaget e Bruner. A noção de auto-aprendizagem e o papel de um problema como ponto inicial da aprendizagem podem ser atribuidos a 
Dewey e ao ideário de motivação intrínseca de Bruner. A ênfase na construção ativa do conhecimento e na testagem de hipóteses são consequências de um processo dedutivo que tem suas bases no racionalismo de Popper e no funcionalismo americano (SCHMIDT 1993, SCHMIDT 2001).

A ABP tem como características essenciais: a construção do conhecimento a partir do próprio aluno, a organização da temática em torno de problemas, a integração interdisciplinar, imbricando componentes básicos e clínicos, e a ênfase no desenvolvimento cognitivo (SOBRAL 1994 ).

Nessa metodologia, o trabalho educativo tem início com um problema bem formulado pelo professor (ou por uma equipe da universidade) para os alunos. Os alunos devem aprender levantando hipóteses de solução para o problema, discutindo com os colegas e pesquisando as teorias subjacentes ao problema apresentado. $\mathrm{O}$ aluno é estimulado a cooperar com os colegas, trabalhando em grupo e articulando a teoria e a prática (SAVERY e DUFFY 1995; VENTURELLI 1997).

Cabe à escola suprir as experiências que permitam ao aluno educar-se, num processo ativo de construção e reconstrução do objeto de conhecimento, numa interação das estruturas cognitivas do individuo e das estruturas do ambiente. Como o conhecimento resulta da ação a partir dos interesses e necessidades, os conteúdos de ensino são estabelecidos em função de experiências que o sujeito vivencia ante desafios cognitivos e situações problemáticas. Valorizam-se mais os processos mentais e as habilidades cognitivas do que conteúdos organizados racionalmente. Trata-se de aprender a aprender, ou seja, é mais importante o processo de aquisição do saber do que o saber propriamente dito.

A idéia de aprender fazendo está sempre presente. Valorizam-se as tentativas experimentais, a pesquisa, a descoberta, o estudo do meio natural e social, o método de solução de problemas. Embora os métodos variem, as escolas ativas ou novas partem sempre de atividades adequadas à natureza do aluno e às etapas de seu desenvolvimento. Na maioria delas, acentua-se a importância do trabalho em grupo, não apenas como técnica, mas como condição básica do desenvolvimento mental. Os passos básicos do método ativo são: a) colocar o aluno numa situação de experiência que tenha interesse por si mesma; b) o problema deve ser desafiante, com estímulo à reflexão; c) o aluno deve dispor de informações e instruções que lhe perrinitam 
pesquisar a descoberta de soluções; d) soluções provisórias devem ser incentivadas e ordenadas, com a ajuda discreta do professor; e) deve-se garantir a oportunidade de colocar as soluções à prova, a fím de determinar sua utilidade para a vida.

O papel do professor é auxiliar o desenvolvimento livre e espontâneo do aluno; se intervém, é para dar forma ao raciocinio. A disciplina surge de uma tomada de consciência dos limites da vida grupal. Assim, aluno disciplinado é aquele que é solidário, participante, respeitador das regras do grupo. Um relacionamento positivo entre professores e alunos é indispensável para instaurar uma vivência democrática, tal qual deve ser a vida em sociedade.

A motivação depende da força de estímulo do problema e das disposições internas e interesses do aluno. Assim, aprender se torna uma atividade de descoberta, é uma auto-aprendizagem, sendo o ambiente apenas o meio estimulador. É retido o que se incorpora à atividade do aluno como descoberta pessoal: o que é incorporado passa a compor a estrutura cognitiva para ser empregado em novas situações. A avaliação é fluida e tenta ser eficaz à medida que os esforços e os êxitos são pronta e explicitamente reconhecidos pelo professor.

Segundo BARROWS (1986), encontram-se na literatura diferentes metodologias que são chamadas de $\mathrm{ABP}$, cada uma com diferentes objetivos. Com a popularização do termo, uma grande variedade de métodos educacionais recebe esse nome, porém o que existe de comum nas várias referências à $\mathrm{ABP}$ seria a utilização de problemas como ponto inicial do processo educativo. A ABP pode ser descrita e avaliada em função do tipo de problema utilizado, da seqüência ensino-aprendizagem, da responsabilidade do estudante na aprendizagem e da avaliação do método usado. Para o autor, existem diferenças nos objetivos educacionais das diferentes abordagens, e a potencialidade do enfoque de ABP é especialmente apropriada para quatro objetivos curriculares: 1) estruturação de conhecimento para aplicação em contextos clínicos; 2) desenvolvimento do processo de um raciocínio clínico eficaz; 3) desenvolvimento de aprendizagem autodirigida; 4) motivação para aprender.

WALTONS e MATTEWS (1989) consideram que não existe consenso do que seja ABP. O princípio da ABP seria colocar os estudantes em uma situação particular semelhante à encontrada na prática profissional, na qual a resolução da tarefa seja uma fonte de aprendizagem. Comentam que a questão mais importante da $\mathrm{ABP}$ seria 
o desenvolvimento do raciocínio crítico nos alunos (através de uma estratégia planejada e com o aumento da experiência com diferentes problemas), mais eficiente do que os alcançados através de métodos tradicionais, os quais só acabam acontecendo após o término da graduação e a partir da prática profissional.

Há uma diversidade de abordagens nos vários currículos de ABP. Em algumas instituições a ABP é usada exclusivamente como estratégia educacional, além das classes habituais ou conferências; em outras, há certos períodos reservados para abordagens baseadas em problemas. Há aquelas que utilizam currículos quase que exclusivamente aplicados na $\mathrm{ABP}$ e outras que utilizam um curriculo inicialmente de dois ou três anos, com parte de ABP e parte tradicional, de modo a integrar as ciências básicas com as ciências clínicas. Atualmente a ABP também é utilizada em cursos como arquitetura, enfermagem, engenharia, serviço social, ciências do meio ambiente, economia, direito e tecnologia (BLIGH 1995).

VENTURELLI (1997) acredita que essa metodologia tem a possibilidade de ajudar o aluno a integrar conceitos e de ajudar a compreender os problemas a partir da sua determinação, a partir das necessidades prioritárias de saúde da população. Pressupõe para isso um enfoque educativo flexível, que permite e promove a avaliação e as mudanças de forma permanente. Para ele, o uso de problemas de saúde permite a integração dos docentes entre si e desses com os e estudantes, ao mesmo tempo que busca uma resposta social mais adequada às necessidades prioritárias de saúde. De maneira sintética, o autor compara os modelos curriculares inovador e tradicional no quadro a seguir.

\begin{tabular}{|l|l|}
\hline $\begin{array}{l}\text { Modelo inovador (aprendizagem baseada em } \\
\text { problemas) }\end{array}$ & Modelo tradicional \\
\hline Centrado no aluno & Centrado no docente \\
\hline Uso de recursos audiovisuais múltiplos e relevantes & Uso de exposições/repetitivo \\
\hline Avaliação formativa continua & Avaliação somativa \\
\hline $\begin{array}{l}\text { Considera qualidades pessoais e estilos. Promove a } \\
\text { destreza educacional }\end{array}$ & Não dá espaço ao indivíduo \\
\hline Auto-aprendizagem & Programas estabelecidos \\
\hline Integra conceitos & Seqüencial, impositivo \\
\hline Organizado em grupos & Individualizado \\
\hline $\begin{array}{l}\text { Baseado nas necessidades prioritárias de saúde e na } \\
\text { atenção primária }\end{array}$ & $\begin{array}{l}\text { Centrado no hospital e em } \\
\text { patologias }\end{array}$ \\
\hline
\end{tabular}

Extraido de BATISTA e SILVA (1998) 
BYRNE e ROSENTHAL (1994), entretanto, consideram que há uma atenção desproporcional à Aprendizagem Baseada em Problemas se considerarmos a magnitude das mudanças que ela representa em termos de ensino e as conseqüências de sua utilização para uma formação integral do aluno. Das 1.350 escolas de medicina no mundo, apenas sessenta introduziram a ABP como uma nova possibilidade para formar médicos. O que talvez os autores desconsideram são as dificuldades de implantar um novo modelo de educação e modificar antigos hábitos arraigados e talvez mais que isso, a mudança de um paradigma em educação.

A ABP, quando utilizada na estrutura curricular, se propõe a melhorar a formação dos alunos, estimulando a auto-aprendizagem, o raciocínio crítico e o trabalho em grupo.

Para alguns autores, a ABP tem a preocupação de integrar o conhecimento e de possibilitar que os alunos trabalhem a partir da realidade sociossanitária de sua comunidade (VENTURELLI 1997; BARROWS 1996). Outros consideram que somente uma mudança na metodologia não teria este impacto (BYRNE e ROSENTHAL 1994).

Será que a ABP abriria a possibilidade de se trabalhar com problemas polidisciplinares, transversais, e multidimensionais como os que vivemos atualmente? Será que a partir de um currículo no contexto da ABP é possível caminhar na direção de uma maior integração? Com a possibilidade da construção ativa do conhecimento, um rompimento com a estrutura academicista centrado no professor e com a fragmentação do conhecimento, seria possível buscar um novo modelo de ensino?

$\mathrm{Na}$ literatura estudada observou-se um amplo consenso em torno da necessidade de mudanças na educação médica. Entretanto há uma diversidade de objetivos e propostas a respeito de qual direção deve-se tomar a promoção dessas mudanças. Alguns querem mudar a educação médica para que a formação dos médicos se oriente por novos valores e novas práticas e transformá-la em função das necessidades e direitos dos cidadãos, outros querem atualizá-la rumo às modificações na organização dos serviços de saúde. Há ainda os que querem restaurar o passado, recuperando o sonho liberal ou ressuscitando a medicina de família (PAIM 1994). 
Em síntese, a reforma da educação médica é uma proposição justa e factivel para a sociedade, e à universidade cabe um papel hegemônico nessa discussão, já que a escola médica tem o compromisso social de educar o futuro profissional para atuar de forma integrada no processo saúde-doença, de modo a atender às necessidades de saúde da população.

Assim, justifica-se a realização de uma pesquisa que descreva a reforma curricular que têm sido experimentada em uma escola médica com larga experiência em mudança educacional e que pretende formar médicos para o exercício de uma prática integral. 
Objetivos 


\section{Geral:}

- Sintetizar princípios e analisar a relevância, conceitos e práticas de uma reforma curricular em uma escola médica.

\section{Especificos:}

- Descrever o processo de tomada de decisão relacionada à reforma do currículo médico da Escola de Medicina da Universidade do Novo México.

- Descrever e analisar o processo educativo e as estratégias de ensinoaprendizagem utilizados pela escola.

- Identificar como a escola de medicina prepara os estudantes para resolver problemas de saúde e colaborar no atendimento às necessidades da população. 


\section{Capítulo 2}

Metodologia 


\section{Metodologia}

\subsection{A PESQUiSA QUALITATIVA}

A opção pela realização de uma pesquisa de caráter qualitativo para estudar a reforma curricular na Escola de Medicina do Novo México deveu-se não só às características do objeto estudado, mas também porque esta abordagem permite captar a realidade dinâmica e complexa da reforma curricular dentro da própria escola, ou seja, no seu contexto histónico. O ambiente social é a fonte de dados e, como estes são predominantemente explicativos, a ênfase foi maior no processo que do no produto. $O$ foco de atenção centrou-se no significado que as pessoas dão às coisas que estão sendo vividas e na perspectiva dos participantes com relação aos fatos (LUDKE e ANDRÉ 1986).

MINAYO (1994) reflete que existem quatro aspectos importantes a serem considerados para a análise de uma pesquisa qualitativa. Em primeiro lugar, dentro de uma perspectiva dialética, o conhecimento é uma construção que se faz a partir de outros conhecimentos e tem um caráter aproximativo, pois é por meio de muitas tentativas e da incidência de pontos de vista diferentes que se vai dando formas mais definidas ao objeto. Um segundo aspecto é a inatingibilidade do objeto, ou seja, as idéias que fazemos sobre os fatos são sempre menos precisas do que ele próprio, de modo que o processo de pesquisa consiste na definição e redefinição do objeto, pois seu conhecimento é fruto da cooperação do trabalho sobre as descobertas uns dos outros e também porque cada teoria formula o objeto segundo seus pressupostos. Em terceiro lugar está a vinculação entre o pensamento e a ação, ou seja, nada é um problema se não tiver sido antes um problema na vida prática. A escolha de um tema não ocorre espontaneamente, surge de interesses e circunstâncias socialmente condicionados. O quarto ponto enfatiza o caráter interessado do conhecimento, apesar da sua relativa autonomia. O olhar sobre o objeto está historicamente condicionado pela posição social do pesquisador e pelas correntes de pensamento em conflito na sociedade. 


\subsection{ESTUdo dE CASO}

Dentre os vários tipos de abordagem qualitativa, optou-se pelo estudo de caso, que se caracteriza por enfatizar a interpretação em contexto, o que significa que para uma apreensão mais completa do objeto é preciso levar em conta a sua inserção social e as interações em que ele se situa. Nesse tipo de estudo, busca-se retratar a realidade e revelar a multiplicidade de dimensões presentes numa variedade de fontes de informação: os dados são coletados de diferentes tipos de informantes. O estudo de caso busca revelar a idiossincrasia e a particularidade de eventos singulares, o que implica analisá-lo como uma representação peculiar e profunda de uma realidade complexa, multidimensional e historicamente situada. Ao representar uma instância em sua totalidade, esse tipo de abordagem promove um conhecimento mais concreto, mais contextualizado e mais suscetível às interpretações do leitor (LUDKE e ANDRÉ 1986).

Segundo Tellis, o estudo de caso é utilizado principalmente em trabalhos sociológicos porém atualmente encontra-se em número cada vez maior na área da educação, quando se deseja uma investigação detalhada sobre o problema. Os dados gerados por um caso funcionam como um corte transversal que facilita a compreensão do fenômeno. $\mathrm{O}$ estudo de caso tem sido empregado para explicar vínculos causais em intervenções do cotidiano, descrever o real contexto de vida em que a intervenção aconteceu, descrever a intervenção propriamente dita e explorar situações em que a intervenção vem sendo avaliada em um conjunto de resultados (TELLIS 1997a,b).

Em termos esquemáticos, o estudo de caso se caracteriza por três fases: uma chamada de aberta ou exploratória, outra que contempla a coleta de dados e uma que realiza a análise dos dados e a elaboração de um relatório. Essas três fases se superpõem em diversos momentos, sendo dificil precisar as linhas que as separam (LUDKE e ANDRÉ 1986).

A fase exploratória é fundamental para a definição mais precisa do objeto de estudo. É o momento de especificar as questões ou pontos críticos, de estabelecer os contatos iniciais para a entrada em campo, de localizar os informantes e as fontes de dados necessários para o estudo. A imersão na problemática em estudo realizou-se através do acompanhamento de duas turmas de alunos, dos contatos com 
coordenadores e demais membros da equipe de coordenação e da participação nas reuniões. Foram identificadas pessoas-chave que forneceram informações a respeito do currículo anterior e da reforma curricular realizada. Na Escola de Medicina da Universidade do Novo México efetuaram-se também a busca e a análise dos documentos existentes sobre a reforma curricular, objetivando-se conhecer as alterações curriculares, os processos de ensino e aprendizagem, a avaliação e a implantação e generalização do processo de mudança.

\subsubsection{COlETA DE DADOS}

A segunda etapa realizada foi a coleta de dados. Os dados coletados foram analisados através da triangulação metodológica, em que se empregaram múltiplos meios de pesquisa para analisar o problema (PATTON 1987). Essa metodologia é fundamental para verificar a propriedade das interpretações originadas a partir dos dados qualitativos (MENDES 2000). A utilização de multimeios na proposta de triangulação garante maior validade dos dados, pois os problemas e limitações de determinado método pode ser compensado pelo uso de outros métodos. Nessa estratégia, as ações sociais e as falas dos atores devem ser contextualizadas para que seja possível esclarecer e aprofundar aspectos da realidade.

O presente trabalho usou quatro parâmetros na coleta de dados, conforme sugeridos por MILES e HUBERMAN (1984): (1) o cenário onde a pesquisa teve lugar, (2) os atores que foram observados e entrevistados, (3) os eventos ocorridos, (4) o processo, a evolução da natureza do evento empreendido pelos atores dentro do cenário.

A história e a cultura da Escola de Medicina da Universidade do Novo México foram estudadas por meio de dados secundários, dos documentos publicados, de entrevistas com os professores da Escola de Medicina e conversas informais com docentes, alunos e técnicos da área da saúde.

\section{A - Observação}

- dos alunos e docentes nas suas atividades diárias 
O trabalho teve início no momento da chegada da pesquisadora ao campo, com as atividades de observação dos tutoriais, realizados em pequenos grupos de alunos utilizando-se como metodologia a Aprendizagem Baseada em Problemas. O tutorial consiste na discussão de um caso em grupo (6 a 8 estudantes) e um ou dois tutores que atuam como facilitadores da aprendizagem. Foi observada a dinâmica do grupo, a participação e o envolvimento dos estudantes nas discussões, a apresentação dos casos, o processo de construção do conhecimento e a atuação do tutor (roteiro anexo 1).

- das reuniões de docentes e coordenadores

Existem diferentes espaços de discussão entre os docentes e os coordenadores. Foi possivel participar das reuniões semanais em que os tutores discutem e se preparam para os tutoriais. Também foi possivel participar das reuniões mensais de atualização em educação e saúde e de diferentes eventos relacionados à formação dos docentes da Escola de Medicina.

\section{B - Análise documental}

A análise documental constituiu-se do levantamento e leitura do material documental disponível a respeito da reforma curricular na Escola de Medicina da Universidade do Novo México. O conjunto documental reunia memorandos, documentos administrativos internos e externos, artigos, publicações da universidade e sua página eletrônica com informações diversas. Esse material também ajudou a compor a histónia do currículo anterior e atual.

\section{C - Conversas informais}

Através de conversas informais com docentes e alunos do curso médico da universidade, bem como com profissionais da área da saúde do Estado do Novo México (NM), foi possivel reunir informações complementares que auxiliaram no delineamento do caso. As conversas informais usualmente ocorreram antes ou depois das aulas, reuniões ou oficinas de trabalho. 


\section{D - Entrevistas}

As entrevistas foram feitas com docentes e coordenadores de blocos que participaram da última reforma curricular ocorrida na Escola de Medicina na UNM e foram estudadas no cotidiano de sua ação, ou seja, na própria escola. Os docentes foram convidados a participar da pesquisa pessoalmente e assinaram um termo de consentimento (anexo 2) antes de sua realização.

Seguindo um roteiro de questões semi-estruturadas (anexo 3), em que 0 entrevistado falou sobre o tema proposto, cada entrevista permitiu a compreensão da dimensão da subjetividade dos indivíduos em suas representações e na relação dinâmica que se estabelece nas estruturas sociais, como também no aprofundamento das informações (OLIVEIRA 1999).

Pesquisadores nacionais e internacionais com grande experiência em estudos de caso ressaltam que esta abordagem não é uma pesquisa por amostragem. Isso significa que não é necessário estabelecer a priori um determinado número de entrevistas para a compreensão do tema (LUDKE e ANDRÉ 1986; TRIVIÑOS 1987; TELLIS 1997a). Para definir o número de entrevistas, empregou-se o critério de saturação, isto é, a coleta de dados terminou quando os conteúdos das entrevistas começaram a se repetir.

Segundo TRIVIÑOS (1987), o processo de escolha de um bom informante é essencial quando se deseja estudar um fenômeno social ou uma atividade especifica. Considerando esse aspecto, foram escolhidos os informantes deste estudo, ou seja, foram selecionados informantes-chave, em uma amostra intencional. Julgou-se importante entrevistar os docentes que desde o início tiveram um papel fundamental na inovação curricular, os que têm atualmente envolvimento com os tutoriais e a educação dos alunos de medicina e aqueles que têm um conhecimento amplo e detalhado das circunstâncias da reforma curricular.

Os informantes deste estudo foram os docentes e técnicos da Escola de Medicina da UNM. Tanto foram entrevistados os tutores de cadeiras básicas como os coordenadores dos diferentes módulos do currículo. Foram realizadas catorze entrevistas, com docentes de cadeiras básicas e clínicas, ou seja, entre os entrevistados 
havia cinco médicos e oito cientistas básicos e um técnico. Os docentes entrevistados nesse trabalho estavam todos efetivamente envolvidos no ensino nos quatro anos do curso médico, seja nos tutoriais de aprendizagem baseada em problema, seja nas aulas, nas sessões de laboratório ou no ensino de clínica.

As entrevistas foram feitas em gravador comum e transcritas literalmente por um profissional da própria cidade, com exceção de duas que, realizadas em espanhol, foram transcritas pela própria pesquisadora. Duas entrevistas não puderam ser utilizadas, uma por solicitação do entrevistado, que preferiu não tê-la gravada, e outra por estar inaudivel.

\subsection{A SISTEMÁTICA PARA ORGANIZAÇÃO E INTERPRETAÇÃO DOS DADOS}

A terceira fase constituiu-se na sistematização, organização e interpretação dos dados. $\mathrm{Na}$ organização dos dados decorrentes das entrevistas usou-se o código $\mathrm{P}(\mathrm{n})$ para denominar cada um dos professores entrevistados e $C(n)$ para denominar as conversas informais realizadas.

Para o tratamento das entrevistas, utilizamos um método de análise desenvolvido por LEFÈVRE e LEFÈVRE (1999) e LEFÈVRE, LEFÈVRE e TEIXEIRA (2000), denominado Discurso do Sujeito Coletivo (DSC), tendo como objetivo a organização dos dados discursivos, em que foram empregadas três figuras:

a) a idéia central, que é uma transcrição fiel de partes significativas dos depoimentos e permite traduzir o essencial do conteúdo discursivo explicitado pelos sujeitos em seus depoimentos;

b) as expressões-chave, que são transcrições literais de partes mais significativas dos depoimentos e permitem o resgate essencial do conteúdo discursivo dos segmentos em que se divide o depoimento;

c) a construção do Discurso do Sujeito Coletivo (DSC), é elaborado a partir dos discursos em estado bruto então submetidos a um trabalho analítico inicial de decomposição, que consistiu na seleção das principais idéias centrais presentes em cada um dos discursos individuais e na reconstituição discursiva da representação social. Os depoimentos equivalentes são sistematizados e apresentados em um só discurso-sintese. 


\section{O disCURSO dO SUJEITO COLETIVO}

Ao utilizar-se o Discurso do Sujeito Coletivo como instrumento de organização e análise das entrevistas, foi necessário um grande e exaustivo trabalho de preparação, e isso fez com que o depoimento dos entrevistados fosse ficando cada vez mais claro para o pesquisador e propiciando uma enorme satisfação ao se descortinar um entendimento mais global das entrevistas e da problemática em estudo. A organização dos dados decorrentes das entrevistas compôs-se de quatro etapas:

$1^{\text {a }}$ etapa: as entrevistas foram lidas exaustivamente e algumas foram ouvidas novamente para assegurar um bom entendimento do que havia sido dito;

$2^{\mathrm{a}}$ etapa: as entrevistas foram traduzidas integralmente, utilizando-se um programa denominado Micropower Delta translator 2.0. Após a tradução com o programa, foi necessário um longo processo de leitura para a correção gramatical, sendo preciso voltar repetidas vezes ao texto em inglês até que se considerasse haver fidelidade no que havia sido dito.

$3^{a}$ etapa: resgate das falas dos informantes para cada uma das questões propostas na entrevista, o que se chamou expressões-chave, então colocadas em um quadro. Algumas questões foram fundidas pela similaridade e repetição das respostas dadas. As expressões-chave transcritas foram lidas e relidas até se chegar às idéias centrais, que foram listadas em um único documento e colocadas, uma a uma, ao lado das expressões-chave correspondentes, lidas, relidas e sintetizadas para a etapa seguinte;

$4^{\mathrm{a}}$ etapa: a partir do quadro das idéias centrais e expressões-chave construiu-se um discurso-sintese, como se fosse um só sujeito falando, como se um só sujeito expressasse um discurso-síntese, o Discurso do Sujeito Coletivo.

Após a realização da primeira e da segunda etapa da audição, tradução e correção gramatical de cada uma das entrevistas, partiu-se para a organização dos depoimentos para obter o Discurso do Sujeito Coletivo. Esse procedimento foi feito com cada uma das perguntas do roteiro, que contou com cinco tópicos principais: geral, reforma curricular, educação médica, necessidades de saúde do Estado do Novo 
México e desenvolvimento de casos. Em cada um dos tópicos foram feitas dezoito perguntas ao todo. Em cada uma delas perguntas foi efetuado o tratamento dos dados para se chegar ao Discurso do Sujeito Coletivo.

A título de exemplo, vejamos a seguir as etapas realizadas para se chegar ao Discurso do Sujeito Coletivo a partir das respostas à questão $n^{\circ} 1$.

A terceira etapa foi mostrada no quadro abaixo, onde em cada depoimento buscou-se a resposta para a primeira pergunta da entrevista e extrairam-se as expressões-chave e as idéias centrais correspondentes.

\section{Questão n ${ }^{\circ} 1$ - Você foi tutor no currículo de cuidados primários em saúde (CCPS)?}

Se sim, fale-me sobre isso (sentimentos, percepções).

\begin{tabular}{|c|c|}
\hline Expressões-chave & Idéia central \\
\hline $\begin{array}{l}\text { Foi uma experiência maravilhosa, centrada no aluno, } \\
\text { aprendizagem baseada em problemas, tutorial em } \\
\text { pequeno grupo. A característica impar era a } \\
\text { experiência de cuidado primário rural no final do } \\
\text { primeiro ano médico. Do ponto de vista profissional, } \\
\text { proporcionava aos alunos uma experiência real de ver } \\
\text { o que era a medicina, e eles podiam avaliar o quanto } \\
\text { um médico em área rural deveria saber o que dava a } \\
\text { eles a perspectiva do quanto eles precisavam estudar. } \\
\text { Era um pequeno grupo de alunos, era como uma } \\
\text { familia. Dr. Xe eu começamos e eu penso que antes nós } \\
\text { não tínhamos muito prazer em participar da escola } \\
\text { médica, não era prazeroso, e quando começamos nós } \\
\text { dois sentimos que aprender era prazeroso, medicina era } \\
\text { prazerosa e aprender medicina podia ser prazeroso } \\
\text { P(2). }\end{array}$ & $\begin{array}{l}\text { Foi uma experiência maravilhosa, } \\
\text { era como uma famillia, um } \\
\text { pequeno grupo de professores e } \\
\text { um pequeno grupo de alunos, era } \\
\text { uma experiência prazerosa. }\end{array}$ \\
\hline $\begin{array}{l}\text { A inovação começou por causa de uma necessidade do } \\
\text { Estado, não porque eles acreditavam ser necessário } \\
\text { desenvolver uma proposta inovadora em educação, isso } \\
\text { seria como você reorganiza a educação começou por } \\
\text { causa da crise em nosso Estado. Os médicos de cuidado } \\
\text { primário não eram suficiente em áreas rurais. Eu penso } \\
\text { que qualquer inovação para se sustentar; tem que } \\
\text { encontrar um movimento importante na sociedade. Não } \\
\text { pode ser somente curiosidade filosófica ou intelectual. } \\
\text { A mudança não se sustenta porque as forças contrárias } \\
\text { são tão fortes e tão volumosas que eles serão } \\
\text { esmagados, então tem que encontrar algo na sociedade } \\
\text { que é uma necessidade importante, a qual eles poderão } \\
\text { aliar, isso ajudará proteger a longo prazo } \\
\text { Então a primeira idéia foi, se as pessoas que } \\
\text { começaram CCPS tiveram uma transformação em suas }\end{array}$ & $\begin{array}{l}\text { Inovação na educação aconteceu } \\
\text { porque era uma necessidade do } \\
\text { Estado do NM, esta foi a gêneses } \\
\text { da idéia. } \\
\text { A experiência de transformação } \\
\text { na vida dos docentes e dos alunos } \\
\text { com o currículo. } \\
\text { A abordagem pedagógica se } \\
\text { colocou pela impossibilidade de } \\
\text { locomover os docentes para as } \\
\text { áreas rurais. }\end{array}$ \\
\hline
\end{tabular}




\begin{tabular}{|l|}
\hline Expressões-chave \\
\hline começaram CCPS tiveram uma transformação em suas \\
próprias vidas por causa de suas próprias experiências \\
de trabalho, como os alunos poderiam ter a mesma \\
experiència? Isto é a gènese real da idéia. \\
A utilização da ABP veio depois para resolver um \\
problema. Se os estudantes logo no início iam para a \\
comunidade por longos periodos de tempo, como eles \\
poderiam estudar? Como nós não podiamos ensinar \\
ciência básica e clinica a distância, a ABP da \\
McMaster parecia ser um caminho interessante para \\
ensinar os estudantes a aprenderem por si mesmos P(3)
\end{tabular}

Em primeiro lugar, na estrutura do curriculo o CCPS é $100 \%$ aprendizagem baseada em problema, nenhuma aula.

O CCPS era um grupo selecionado de docentes que era realmente dedicado àquele modo de aprender $e$ aconteceu de serem tutores muito, muito bons. Então $O$ CCPS era um grupo todo mundo que foi tutorado dizia que este método selecionado de docentes.

funciona. A terceira diferença está nos alunos. Aqui todos os alunos, gostando ou não de aprendizagem No CCPS os alunos eram auto baseada em problema, são parte deste processo. No selecionados.

CCPS os alunos eram auto-selecionados, sim, se pensavam que podiam aprender melhor naquele formato eles iam ao CCPS P(4).

Sim, eu realmente fui residente de medicina familiar, quando começou e também tutor de CCPS. O CCPS era um grupo muito especial, um grupo de estudantes à parte de todos, que começou um programa especial, especificamente, os estudantes iriam aprender em grupos pequenos, com um tutor, que pode facilitava a experiencia, diferente de agora. Os estudantes eram mutto entusiasmados com o CCPS. Começamos com um pequeno grupo de professores que tinham interesse nesta abordagem.

Foi um tempo de muito entusiasmo, de educação, era um tempo muito especial. Com o desenvolvimento de programa tínhamos a oportunidade de começar uma outra parte, de por os estudantes na comunidade, porque antes disso os estudantes tinham pouca experiencia, ai tivemos oportunidade de colocar os estudantes por um tempo muito grande (16 semanas) na comunidade, com doutores na comunidade, em uma área rural, e tinham um relacionamento muito especial também, havia muito interesse na comunidade nos aspectos biológicos e nos comportamentais. A experiência foi muito intensa em relação ao método, principalmente para os tutores de medicina familiar e de saúde publica. $P(5)$

\section{Idéia central}

Em primeiro lugar, na estrutura do curriculo o CCPS é 100\% aprendizagem baseada em problema, nenhuma aula.

O CCPS era um grupo muito especial, um grupo de estudantes à parte de todos.

Foi um tempo de muito entusiasmo, de educação, era um tempo muito especial.

$\begin{array}{lcr}\text { Com o desenvolvimento } & \text { de } \\ \text { programa } & \text { tinhamos } & a\end{array}$ oportunidade de começar uma outra parte, de por os estudantes na comunidade...

.. tinham um relacionamento muito especial também, havia muito interesse na comunidade. 


\begin{tabular}{|c|c|}
\hline Expressões-chave & Idéia central \\
\hline $\begin{array}{l}\text { Todo mundo que se inscreveu no CCPS eram alunos } \\
\text { que claramente queriam estar lá. em geral os alunos } \\
\text { eram ligeiramente mais velhos, talvez alunos que } \\
\text { tinham mais experiencia de vida, nesse curriculo é todo } \\
\text {.. e então vocé tinha algumas pessoas que preferiam o } \\
\text { CCPS } \\
\text { O CCPS tinha um grupo de docentes muito pequeno } \\
\text { que estava muito comprometido e havia comunicação, } \\
\text { as pessoas podiam conversar, eu quero dizer, existia } \\
\text { aquela quimica das pessoas se tornaram amigos como } \\
\text { também colegas e eu pensamos que isto, de as pessoas } \\
\text { se tornarem amigas facilitava o convivio e muito dos } \\
\text { assuntos que surgem agora não aconteciam } P(7) \text {. }\end{array}$ & $\begin{array}{l}\text { os alunos eram ligeiramente mais } \\
\text { velhos, talvez alunos que tinham } \\
\text { mais experiencia de vida. } \\
\text { grupo de docentes muito pequeno } \\
\text { que estava muito comprometido e } \\
\text { havia comunicação, }\end{array}$ \\
\hline $\begin{array}{l}\text { OCCPS era diferente, não existia nenhuma conferência } \\
\text { e só aprendizagem em pequenos grupos em sessões } \\
\text { realizadas três vezes por semana. Existiam muito } \\
\text { poucas sessões de laboratório onde os alunos poderiam } \\
\text { ir a um laboratório de fisiologia ou algo assim mas era } \\
\text { basicamente um grupo pequeno com aprendizagem } \\
\text { aluno-centrada } P(8)\end{array}$ & $\begin{array}{l}\text { OCCPS era diferente, não existia } \\
\text { nenhuma conferência e só } \\
\text { aprendizagem em pequenos } \\
\text { grupos }\end{array}$ \\
\hline $\begin{array}{l}\text { Eu tutorei no CCPS e realmente comecei no primeiro } \\
\text { ano. O CCPS foi uma experiência interessante porque } \\
\text { quando foi pedido que eu participasse no seminário de } \\
\text { treinamento dos tutores que estava sendo realizado } \\
\text { antes de nós começarmos o CCPS, eu fiquei realmente } \\
\text { impressionado pela habilidade dos alunos para } \\
\text { aprenderem e no quanto eu adquiri com a experiência } \\
\text { de trabalhar com os alunos, não só no nivel pessoal } \\
\text { mas também na aquisição de conhecimento que eu } \\
\text { adquiri sobre medicina e outras áreas de ciência. Eu } \\
\text { fiquet seduzido por aquela idéia de aluno e docentes } \\
\text { aprenderem juntos. Então, e eu achei que era } \\
\text { prazeroso e eu praticamente tutorei todos os anos no } \\
\text { curriculo de CCPS. P(II) }\end{array}$ & $\begin{array}{l}\text { CCPS era uma experiência } \\
\text { interessante, a proposta era } \\
\text { sedutora. } \\
\text { ganho de experiencia de } \\
\text { aprendizagem em duas vias entre } \\
\text { alunos e professores }\end{array}$ \\
\hline
\end{tabular}

Ainda na terceira etapa foram identificadas e reunidas as idéias centrais de cada uma das perguntas, colocando-se as respectivas expressões-chave que continham a mesma idéia central em cada um dos depoimentos, ou seja, foram selecionados os depoimentos em que os professores expressavam quanto foi prazeroso fazer parte da experiência inicial de trabalhar com o currículo de cuidados primários em saúde (CCPS), como mostrado no quadro a seguir: 
Questão n ${ }^{0} 1$-Você foi tutor no currículo de cuidados primários em saúde? Se sim, fale-me sobre isso (sentimentos, percep̧ões)

\begin{tabular}{|c|c|}
\hline Idéia central & Expressões-chave correspondentes \\
\hline $\begin{array}{l}\text { Foi uma experiencia maravilhosa, } \\
\text { divertida e interessante, era um } \\
\text { grupo muito especial, trouxe uma } \\
\text { transformação na vida das } \\
\text { pessoas }\end{array}$ & $\begin{array}{l}\text { Foi uma experiência maravilhosa, Dr. X e eu } \\
\text { começamos e eu penso que antes nós não tínhamos } \\
\text { muito prazer em participar da escola médica, não era } \\
\text { prazeroso, e quando começamos nós dois sentimos que } \\
\text { aprender era prazeroso, medicina era prazerosa } e \\
\text { aprender medicina podia ser prazeroso P(2). } \\
\text { O CCPS era um grupo muito especial, um grupo de } \\
\text { estudantes à parte de todos, que começou um programa } \\
\text { especial, especificamente, os estudantes aprendiam em } \\
\text { grupos pequenos, com um tutor, como facilitador, } \\
\text { diferente de agora. Os estudantes eram muito } \\
\text { entusiasmados com o CCPS Começamos com um } \\
\text { pequeno grupo de professores que tinham interesse } \\
\text { nesta abordagem. Foi um tempo de muito entusiasmo, } \\
\text { de educação, era um tempo muto especial A } \\
\text { experiência foi muito intensa em relação ao método, } \\
\text { principalmente dos tutores de medicina familiar e de } \\
\text { saúde publica. P(5) } \\
\text { O CCPS foi uma experiência interessante, quando foi } \\
\text { pedido que eu participasse no seminário de } \\
\text { treinamento dos tutores que estava sendo realizado } \\
\text { antes de nós começarmos o CCPS eu fiquei realmente } \\
\text { impressionado com a habilidade dos alunos para } \\
\text { aprenderem e no quanto eu adquiri com a experiência } \\
\text { de trabalhar com os alunos, não só no nivel pessoal } \\
\text { mas também na aquisição de conhecimentos sobre } \\
\text { medicina e outras áreas de ciência. Eu fiquei seduzido } \\
\text { por aquela idéia de aluno e docentes aprenderem } \\
\text { juntos. Então, e eu achei que era prazeroso e eu } \\
\text { praticamente tutorei todos os anos no curriculo de } \\
\text { CCPS P(ll). } \\
\text { O CCPS trouxe uma transformação na vida de seus } \\
\text { participantes que queriam que os alunos tivessem estas } \\
\text { mesmas experiências P(3). }\end{array}$ \\
\hline
\end{tabular}




\begin{tabular}{|c|c|}
\hline Idéia central & Expressões-chave correspondentes \\
\hline $\begin{array}{l}\text { Era } 100 \% \text { aprendizagem baseada } \\
\text { em problemas, centrada no aluno, } \\
\text { não havia aulas. }\end{array}$ & $\begin{array}{l}\text { Em primeiro lugar, na estrutura do currículo o CCPS } \\
\text { era lo0\% aprendizagem baseada em problema, } \\
\text { nenhuma aula. Então todo mundo que foi tutorado } \\
\text { dizia que este método funciona. A terceira diferença } \\
\text { está nos alunos. Aqui todos os alunos, gostem ou não } \\
\text { de aprendizagem baseada em problema são parte deste } \\
\text { processo. O CCPS era diferente, não existia nenhuma } \\
\text { conferència e só grupo pequeno aprendendo em } \\
\text { sessóes realizadas três vezes por semana. Existiam } \\
\text { muito poucas sessões de laboratório onde os alunos } \\
\text { poderiam ir a um laboratório de fisiologia ou algo } \\
\text { assim mas era basicamente um grupo pequeno com } \\
\text { aprendizagem aluno-centrada P(8). } \\
\text { Era centrado no aluno, aprendizagem baseada em } \\
\text { problemas, tutorial em pequeno grupo, a caracteristica } \\
\text { impar era a experiência de cuidado primário rural no } \\
\text { final do primeiro ano médico, do ponto de vista } \\
\text { profissional, proporcionava uma experiência real de } \\
\text { ver o que a medicina era, e eles avaliavam o quanto } \\
\text { um médico em área rural sabia e dava a eles a } \\
\text { perspectiva do quanto eles precisavam trabalhar. Era } \\
\text { como uma familia, com um número pequeno de alunos } \\
\text { P(4). } \\
\text { A utilização da ABP veio depois para resolver um } \\
\text { problema. Se os estudantes logo no início iam para a } \\
\text { comunidade por longos periodos de tempo, como eles } \\
\text { poderiam estudar? Como nós não podiamos ensinar } \\
\text { ciência básica e clínica a distância, a ABP da } \\
\text { McMaster parecia ser um caminho interessante para } \\
\text { ensinar aos estudantes a aprender por si mesmos } \text { (3). }\end{array}$ \\
\hline $\begin{array}{l}\text { Os alunos eram mais velhos, era } \\
\text { um grupo selecionado }\end{array}$ & $\begin{array}{l}\text { Todo mundo que se inscreveu no CCPS eram alunos } \\
\text { que claramente queriam estar lá, em geral os alunos } \\
\text { eram ligeiramente mais velhos, talvez alunos que } \\
\text { tinham mais experiência de vida, nesse curriculo é } \\
\text { todo ... e então você tinha algumas pessoas que } \\
\text { preferiam o CCPS P(6) } \\
\text { No CCPS os alunos eram auto-selecionados, sim, se } \\
\text { pensavam que podiam aprender melhor naquele } \\
\text { formato eles iam ao CCPS } P(4)\end{array}$ \\
\hline $\begin{array}{l}\text { Era um pequeno grupo de } \\
\text { docentes muito comprometido }\end{array}$ & $\begin{array}{l}\text { OCCPS tinha um grupo de docentes muito pequeno } \\
\text { que estava muito comprometido e havia comunicação, } \\
\text { as pessoas podiam conversar, eu quero dizer, existia } \\
\text { aquela quimica das pessoas se tornarem amigas como } \\
\text { também colegas e eu pensamos que isto, de as pessoas } \\
\text { se tornarem amigas facilitava o convivio e muitos dos } \\
\text { assuntos que surgem agora não aconteciam P(7) } \\
\text { O CCPS, era um grupo selecionado de docentes que } \\
\text { era realmente dedicado àquele modo de aprender e }\end{array}$ \\
\hline
\end{tabular}




\begin{tabular}{|c|c|}
\hline Idéia central & Expressões-chave correspondentes \\
\hline & $\begin{array}{l}\text { aconteceu de serem tutores muito, muito bons. No } \\
\text { CCPS os alunos eram auto selecionados, sim, se } \\
\text { pensavam que podiam aprender melhor naquele } \\
\text { formato eles iam ao CCPS } P(4)\end{array}$ \\
\hline $\begin{array}{l}\text { Tivemos a oportunidade de } \\
\text { colocar os estudantes na prática } \\
\text { no final do primeiro ano por um } \\
\text { tempo muito grande }\end{array}$ & $\begin{array}{l}\text { Com o desenvolvimento de programa Tivemos a } \\
\text { oportunidade de começar uma outra parte, de por os } \\
\text { estudantes na comunidade, porque antes disso os } \\
\text { estudantes tinham pouca experiência, ai tivemos } \\
\text { oportunidade colocar os estudantes por um tempo } \\
\text { muito grande (16 semanas) na comunidade, com } \\
\text { doutores na comunidade, em uma área rural, e tinham } \\
\text { um relacionamento muito especial também, havia } \\
\text { muito interesse na comunidade nos aspectos biológicos } \\
\text { e nos comportamentais. P(5) } \\
\text { a caracteristica impar era a experiência de cuidado } \\
\text { primário rural no final do primeiro ano médico, do } \\
\text { ponto de vista profissional, proporcionava uma } \\
\text { experiência real de ver o que medicina era, e eles } \\
\text { avaliavam o quanto um médico em área rural sabia e } \\
\text { dava a eles a perspectiva do quanto eles precisavam } \\
\text { trabalhar }\end{array}$ \\
\hline $\begin{array}{l}\text { A necessidade do Estado era a } \\
\text { gênesis da idéia }\end{array}$ & $\begin{array}{l}\text { A inovação começou por causa de uma necessidade do } \\
\text { Estado, não porque eles acreditavam ser necessário } \\
\text { desenvolver uma proposta inovadora em educação, } \\
\text { isso seria como você reorganiza a educação começou } \\
\text { por causa da crise em nosso Estado. Os médicos de } \\
\text { cuidado primário não eram suficiente em áreas rurais. } \\
\text { Eu penso que qualquer inovação para se sustentar; } \\
\text { tem que encontrar um movimento importante na } \\
\text { sociedade. Não pode ser somente curiosidade filosófica } \\
\text { ou intelectual. A mudança não se sustenta porque as } \\
\text { forças contrárias são tão fortes e tão volumosas que } \\
\text { eles serão esmagados, então tem que encontrar algo na } \\
\text { sociedade que é uma necessidade importante, a qual } \\
\text { eles poderão aliar, isso ajudará proteger a longo prazo }\end{array}$ \\
\hline
\end{tabular}

$\mathrm{Na}$ quarta etapa agregaram-se e encadearam-se discursivamente as expressõeschave das idéias centrais iguais ou equivalentes que nesta questão expressavam quanto foi prazeroso e interessante e quanto a experiência do currículo de cuidados primários em saúde trouxe uma transformação na vida das pessoas. Essas expressõeschave encadeadas é que compõem o Discurso do Sujeito Coletivo: 


\section{Discurso do Sujeito Coletivo \\ Questão n ${ }^{\circ} 1$ - Você foi tutor no currículo de cuidados primários em saúde? Se sim, fale-me sobre isso (sentimentos, percepções)}

\begin{tabular}{|c|c|}
\hline Idéia central & Discurso do Sujeito Coletivo \\
\hline $\begin{array}{l}\text { Foi uma experiència } \\
\text { maravilhosa, divertida e } \\
\text { interessante, era um grupo } \\
\text { muito especial, trouxe uma } \\
\text { transformação na vida das } \\
\text { pessoas }\end{array}$ & $\begin{array}{l}\text { O curriculo de cuidados primários foi uma experiência } \\
\text { maravilhosa, a caracteristica ímpar era a experiência de } \\
\text { cuidado primário rural no final do primeiro ano médico. } \\
\text { Do ponto de vista profissional, proporcionava aos alunos } \\
\text { uma experiência real de ver o que era a medicina, e eles } \\
\text { podiam avaliar o quanto um médico em área rural } \\
\text { deveria saber, o que dava a eles a idéia do quanto eles } \\
\text { precisavam estudar. Era um pequeno grupo de alunos, } \\
\text { era como uma familia. A experiência foi muito boa em } \\
\text { relação ao método, principalmente para os tutores de } \\
\text { medicina familiar e de saúde pública. Aprender e ensinar } \\
\text { medicina podia ser prazeroso e interessante. Eu fiquei } \\
\text { seduzido por aquela idéia de alunos e docentes } \\
\text { aprenderem juntos. Então eu achei que era prazeroso e } \\
\text { praticamente tutorei todos os anos no currículo de CCPS. } \\
\text { As coisas iam bem, mas estavam muito desconcertadas } \\
\text { entre o que acontecia no campus e o que acontecia na } \\
\text { comunidade. Quando então apareceu uma outra fonte de } \\
\text { recursos, começou uma grande batalha... }\end{array}$ \\
\hline $\begin{array}{l}\text { Era } 100 \% \text { aprendizagem } \\
\text { baseada em problemas, } \\
\text { centrada no aluno, não havia } \\
\text { aulas }\end{array}$ & $\begin{array}{l}\text { A utilização da ABP veio depois para resolver um } \\
\text { problema. Se os estudantes logo no inicio iam para a } \\
\text { comunidade por longos periodos de tempo, como eles } \\
\text { poderiam estudar? Como nós não podiamos ensinar } \\
\text { ciência básica e clínica a distância, a ABP da McMaster } \\
\text { parecia ser um caminho interessante para ensinar os } \\
\text { estudantes a aprenderem por si mesmos. Nesse curriculo } \\
\text { paralelo não havia aulas. O curriculo era 100\% } \\
\text { Aprendizagem Baseada em Problema, nenhuma aula. Só } \\
\text { um grupo pequeno aprendendo em sessões realizadas } \\
\text { três vezes por semana. Existiam muito poucas sessões de } \\
\text { laboratório, onde os alunos poderiam ir a um laboratório } \\
\text { de fisiologia ou algo assim, mas era basicamente um } \\
\text { grupo pequeno com aprendizagem aluno-centrada. } \\
\text { Nesse curriculo paralelo não havia aulas. O currículo } \\
\text { era lo0\% Aprendizagem Baseada em Problema, } \\
\text { nenhuma aula. Era um grupo pequeno aprendendo em } \\
\text { sessões realizadas três vezes por semana. Existiam muito } \\
\text { poucas sessões de laboratório, onde os alunos poderiam } \\
\text { ir a um laboratório de fisiologia ou algo assim, mas era } \\
\text { basicamente um grupo pequeno com aprendizagem } \\
\text { aluno-centrada. }\end{array}$ \\
\hline
\end{tabular}




\begin{tabular}{|c|c|}
\hline Idéia central & Discurso do Sujeito Coletivo \\
\hline $\begin{array}{l}\text { Os alunos eram mais velhos, } \\
\text { era um grupo selecionado }\end{array}$ & $\begin{array}{l}\text { Os alunos também eram selecionados, pois escolhiam } \\
\text { aprender daquela forma. Era um grupo muito especial, } \\
\text { os estudantes aprendendo em grupos pequenos, com um } \\
\text { tutor, que era um facilitador da experiência. Os } \\
\text { estudantes eram muito entusiasmados com o currículo. } \\
\text { Foi um tempo de muito entusiasmo, de educação, era um } \\
\text { tempo muito especial. Os alunos que estudaram nesse } \\
\text { programa claramente queriam estar lá, em geral os } \\
\text { alunos eram ligeiramente mais velhos, talvez tivessem } \\
\text { mais experiência de vida. }\end{array}$ \\
\hline $\begin{array}{l}\text { Era um pequeno grupo de } \\
\text { docentes muito comprometido }\end{array}$ & $\begin{array}{l}\text { O grupo de docentes era selecionado e eles eram } \\
\text { realmente dedicados àquele modo de aprender e eram } \\
\text { muito, muito bons. O grupo de docentes era muito } \\
\text { pequeno e estava muito comprometido. Havia } \\
\text { comunicação, as pessoas podiam conversar, eu quero } \\
\text { dizer, existia aquela química das pessoas se tornarem } \\
\text { amigas além de colegas, e como as pessoas eram amigas, } \\
\text { muitos dos assuntos que surgem agora não aconteciam. } \\
\text { No seminário de treinamento dos tutores que foi } \\
\text { realizado antes de nós começarmos o CCPS, eu fiquei } \\
\text { realmente impressionado pela habilidade dos alunos } \\
\text { para aprenderem e no quanto eu adquiri com a } \\
\text { experiência de trabalhar com os alunos, não só no nivel } \\
\text { pessoal, mas também no saber que eu adquiri sobre } \\
\text { medicina outras áreas da ciência. }\end{array}$ \\
\hline $\begin{array}{l}\text { Tivemos a oportunidade de } \\
\text { colocar os estudantes na } \\
\text { prática no final do primeiro } \\
\text { ano por um tempo muito } \\
\text { grande }\end{array}$ & $\begin{array}{l}\text { Com o desenvolvimento do programa Tivemos a } \\
\text { oportunidade de colocar os estudantes em estágio na } \\
\text { comunidade por um periodo de } 16 \text { semanas. Eles ficavam } \\
\text { com os médicos na comunidade, em uma área rural, e } \\
\text { tinham um relacionamento muito especial. Havia muito } \\
\text { interesse na comunidade, nos aspectos biológicos e nos } \\
\text { comportamentais. A caracteristica impar era a } \\
\text { experiência de cuidado primário nural no final do } \\
\text { primeiro ano médico. Esta experiência, do ponto de vista } \\
\text { profissional, proporcionava uma experiência vivencial da } \\
\text { medicina e eles podiam avaliar as necessidades médicas } \\
\text { e o trabalho do médico na área nural, e isso dava a eles a } \\
\text { percepção do quanto eles precisavam preparar-se... }\end{array}$ \\
\hline
\end{tabular}




\begin{tabular}{|c|c|}
\hline Idéia central & Discurso do sujeito coletivo \\
\hline $\begin{array}{l}\text { A necessidade do Estado era a } \\
\text { gêneses da idéia }\end{array}$ & $\begin{array}{l}\text { A inovação começou por causa da necessidade do Estado, } \\
\text { começou por causa da crise em nosso Estado. Os médicos de } \\
\text { cuidados primários não eram suficientes nas áreas rurais. Eu } \\
\text { penso que qualquer inovação, para se sustentar, tem que } \\
\text { encontrar um movimento importante na sociedade. Não pode ser } \\
\text { somente curiosidade filosófica ou intelectual. Isso normalmente } \\
\text { não sustenta a mudança, porque as forças contrárias à ela são } \\
\text { tantas que a inovação logo seria esmagada. Tem que existir um } \\
\text { movimento na sociedade que seja um apoio social a uma } \\
\text { necessidade importante, para se aliar. Isso ajudará a dar } \\
\text { sustentação à mudança a longo prazo. Esta foi a gênesis da idéia } \\
\text { No início do CCPS, com a pressão do Estado e a legislação } \\
\text { a favor, não houve protesto pois o diretor e a legislação } \\
\text { eram favoráveis, o programa era pequeno e contava com } \\
\text { fundos externos, e não preocupava ninguém. Havia gente } \\
\text { que não gostava, mas não se importava, pois ninguém } \\
\text { estava solicitando mudanças, parte dos professores podiam } \\
\text { ensinar da maneira tradicional. Os problemas começaram } \\
\text { quando o grupo de estudantes cresceu de lo para } 20 \\
\text { alunos, de uma turma de } 73 \text {. Além do suporte externo, mais } \\
\text { pessoas de dentro começaram a trabalhar com o programa } \\
\text { e era prazeroso trabalhar com os alunos dessa maneira. As } \\
\text { críticas vinham de parte dos que estavam no campus... Nós } \\
\text { fomos criando um grande número de preceptores e } \\
\text { professores na comunidade, trabalhando bem com os } \\
\text { legisladores nas suas comunidades. }\end{array}$ \\
\hline
\end{tabular}

As narrativas utilizadas no estudo de caso emergiram das entrevistas realizadas e foram construidas com a estratégia do Discurso do Sujeito Coletivo e aparecerão no capítulo 4 destacadas em itálico. 
Capítulo 3

Cenário 


\section{Cenário do estudo}

O presente estudo foi realizado na Escola de Medicina da Universidade do Novo México (EM-UNM), que integra o complexo de saúde denominado Centro de Ciências de Saúde da Universidade do Novo México (HSC).

Este capitulo é o resultado da fase exploratória do presente estudo de caso, quando se buscou conhecer o ambiente, familiarizar-se com o estranho para depois nele se integrar à procura da particularidade dos eventos, da percepção dos atores para compor o caso. O capitulo procede da análise documental e de conversas informais com $\mathrm{C}(2)$ e $\mathrm{C}(3)$.

\subsection{HISTÓRICO}

Fundado em 1889, o campus da Universidade do Novo México (UNM) ocupa cerca de 600 acres de terreno e está situado ao longo da legendária Rote 66, próximo ao centro de Albuquerque. Esta cidade tem em torno de meio milhão de habitantes e é ladeada pelas montanhas Sandia e o histórico rio Grande. A UNM tem um campus bastante original, com uma releitura arquitetônica de origem espanhola denominada Pueblo, e um arboreto nacionalmente reconhecido em termos de botânica (THE UNIVERSITY OF NEW MEXICO s/d a).

Em 1999, a UNM abrigava 24.250 estudantes no campus situado em Albuquerque, com uma idade média de 28 anos e origem variada, com $27,7 \%$ dos alunos latinos e $11 \%$ de indigenas nativos. A universidade é uma grande fonte de empregos no Estado, contando com 22.600 empregados (THE UNIVERSITY OF NEW MEXICO s/d a).

Dentre os programas da universidade, os que contam com reconhecimento internacional encontram-se na Escola de Medicina propriamente dita, com seu inovador programa de medicina rural e familiar. Outras áreas como fotografia, artes, antropologia, dança flamenca, estudos latino-americanos e biologia também gozam de boa reputação. $\mathrm{Na}$ universidade, as unidades de pesquisa com considerável reconhecimento são a Engenharia, o Centro de Computação, o Centro de Tratamento de Câncer e o Centro de Tecnologia de Materiais. 


\subsection{Centro de CiênCias da Saúde (HSC)}

O Centro de Ciências da Saúde (HSC) é o maior centro de atenção à saúde, ensino e pesquisa do Estado, conta com 639 profissionais (entre docentes e técnicos) e aproximadamente 2 mil estudantes. Fazem parte do complexo de ciências da saúde a Faculdade de Enfermagem, a Faculdade de Farmácia, a Escola de Medicina e a Biblioteca de Ciências da Saúde. O complexo clínico do HSC conta com o Hospital Universitário (384 leitos), o Centro de Cuidados Ambulatoriais (60 clínicas), a Clínica de Saúde Familiar (4 clínicas), o Centro de Prática de Família, o Centro Universitário de Saúde da Mulher, o Hospital da Criança, o Hospital Psiquiátrico da Criança, o Centro de Tratamento e Pesquisa em Câncer, o Carrie Tinglet Hospital (crianças), o Centro de Saúde Mental e o Centro de tratamento de alcoolismo e drogadição. São atendidos neste complexo uma média de 120 mil pacientes por ano. Através do Programa de Ciências Diagnósticas e Terapêuticas, existem três diferentes cursos: Curso de Terapia Ocupacional, Curso de Fisioterapia e Curso de Assistente Médico. Há também cursos técnicos como os de Técnico de Higiene Dentária, Técnico de Laboratório de Medicina Nuclear e Técnico em Radiologia. O curso de Assistente Médico (physician assistent) é relativamente novo e foi estruturado para facilitar o acesso da população do NM aos cuidados primários em saúde. Ė um curso em período integral, com duração de dois anos, que treina profissionais para realizarem procedimentos de saúde com a população, sempre sob a responsabilidade de um médico (THE UNIVERSITY OF NEW MEXICO 1998b; THE UNIVERSITY OF NEW MEXICO 1998c).

A missão preliminar do Centro de Ciências da Saúde é melhorar a saúde dos cidadãos do Novo México através da educação, pesquisa e assistência médica. Seus objetivos são educar e treinar profissionais de saúde, facilitar o desenvolvimento do conhecimento e da pesquisa e fornecer à população usuária os recursos médicos disponiveis na atualidade. Com a pesquisa, o centro procura responder às perguntas essenciais da biologia humana na saúde/doença e estar à frente dos cuidados clínicos. A integração dos programas e o alinhamento das missões múltiplas desse complexo de saúde, segundo os documentos, devem dirigir-se às necessidades relativas aos 
cuidados da saúde das populações rurais e urbanas do Novo México (THE UNIVERSITY OF NEW MEXICO, s/d a).

O HSC tem como prioridade desenvolver e integrar programas e estabelecer acordos com instituições cujas ações estejam voltadas para a melhoria da situação de saúde da comunidade, assegurar o acesso da população aos cuidados da saúde e preparar recursos humanos em saúde adequados para os quadros do Estado, em parceria com o Departamento de Saúde do NM. No Serviço de Saúde dos Indígenas, no Instituto de Doenças Respiratórias, no Laboratório Sandia, no complexo hospitalar Lovelace, no Laboratório Nacional de Los Alamos e na Fundação Nacional de Imagem, em cada uma dessas parcerias, o HSC procura fornecer ensino, pesquisa e serviços de saúde à comunidade.

A Escola de Medicina da UNM é considerada nos Estados Unidos uma das mais importantes em educação médica, dirigida para a formação de médicos de cuidados primários em saúde e também como a mais experiente na utilização da metodologia de ensino denominada Aprendizagem Baseada em Problemas na educação médica (BOADEN e BLIGH 1999). Os estudantes são treinados no Hospital Universitário anexo à Escola de Medicina e em clínicas urbanas e rurais no Estado do Novo México.

\subsection{Perfil dos estudantes da escola de Medicina do Novo México (EM- UNM)}

Em termos populacionais, o Estado do Novo México constitui uma mistura étnica em que, em média $36 \%$ são de origem hispânica, $8 \%$ de origem indígena e $52 \%$ são anglos (THE UNIVERSITY OF NEW MEXICO, s/d a).

$\mathrm{Na}$ amostra de alunos de 1998, numa classe de 73 alunos, encontravam-se 19 hispânicos, 3 indígenas, 6 asiáticos e 45 anglos. Do total, 42 eram mulheres e trinta e um eram homens. Sessenta e oito alunos eram residentes no Novo México e somente 5 eram de outro Estado. A média de idade no início do curso de medicina é de 26 anos (tendo o mais novo 20 anos e o mais velho 43 anos). É necessário explicar que os alunos, para estudar medicina, necessitam ter concluido um curso universitário anterior. Não há vestibular, porém os estudantes têm que se inscrever para uma 
seleção. Neste grupo (1998), 27 estudantes tinham sido rejeitados mais de uma vez no processo de seleção. Um dos critérios utilizados, além das notas do curso de graduação, é o aluno ser residente no Estado do Novo México (THE UNIVERSITY OF NEW MEXICO, s/d b).

\subsection{Situação de Saúde do Estado do Novo México}

Como a prioridade do Centro de Ciências da Saúde é a formação de médicos para atender às necessidades prioritárias da população, foi preciso conhecer a situação da saúde no Estado, para poder analisar se a proposição se concretiza na prática de ensino. Fez então um curto levantamento que teve por base o último relatório realizado pelo Departamento de Saúde do Estado do Novo México (NEW MEXICO DEPARTMENT OF HEALTH 2000a; 2000b). Neste foram identificados doze tópicos que representam os principais problemas de saúde da população do Estado:

(1) Saúde materna e infantil: segundo o relatório do departamento, aproximadamente $60 \%$ das gestações no NM não são planejadas, porém, $90 \%$ das mulheres procuram atenção pré-natal a partir do primeiro semestre. São reportados como importantes problemas entre as mulheres o uso de drogas, álcool e fumo. Com relação às crianças, o baixo peso e defeitos ao nascer. A mortalidade infantil geral é de $6 / 1.000$, com um alto componente de síndrome de morte súbita.

Quanto à (2) Saúde da criança, uma das principais questões que afetam as crianças do NM está relacionadas a acidentes fatais e não-fatais devidos à violência. Abuso e negligência infantil apresentam também índices elevados. Em cada 1.000 pessoas com idade de 0 a 18 anos, ocorrem 50 eventos de abusos não fatais ou negligência. Há uma alta proporção de gravidez na adolescência, 18\% dos nascimentos no Estado são de mães adolescentes. Cerca de $42 \%$ das crianças nascem de mães solteiras e aproximadamente $23 \%$ das crianças novo-mexicanas não têm seguro de saúde

As (3) Doenças infecciosas como a hepatite, são um grande problema de saúde no NM. O Estado tem a mais alta taxa de hepatite A nos Estados Unidos, sem contar que as hepatites $\mathrm{B}$ e $\mathrm{C}$ também apresentam altas taxas. $\mathrm{O}$ número de casos de infeções decorrentes de água e alimentos insalubres no $\mathrm{NM}$ é alto, comparativamente ao 
restante dos Estados Unidos. É igualmente alta a taxa de mortalidade por contaminação alimentar. Outras doenças infecciosas freqüentes no NM são pneumonia, sarampo, meningite, shiguelose e giardiase entre crianças que ficam em creches (child doy-care center).

As (4) Doenças sexualmente transmissíveis como clamidia, gonorréia e AIDS são as principais doenças contagiosas no Estado. Em 1996, foram reportados 260 casos de clamídia por 100 mil pessoas, enquanto esta taxa nos EUA é de 195 casos. Com relação à gonorréia, 57/100.000, apesar de ser um problema importante no Estado, a taxa é bem mais baixa do que no restante do pais.

A principal causa de morte entre crianças e adultos no NM, são os (5) acidentes causados por colisão de automóveis, quedas, afogamento, queimaduras e envenenamentos (lesões externas não intencionais). A maioria dos casos (53\%) entre os acidentes não- intencionais estão relacionados a acidentes envolvendo veículos a motor, os quais afetam principalmente os jovens. A velocidade e o uso de álcool e drogas estão freqüentemente associados a esse tipo de agravo (47\%). O NM tem a mais alta taxa de acidentes fatais relacionados ao álcool dos EUA.

A segunda e terceira causa de morte entre os novo-mexicanos entre os 15 e 24 anos são devidas à (6) Violência, especialmente homicídios e suicídios. Violência doméstica, abuso infantil, abuso sexual e de idosos são outros tipos de violência que ocorrem no Estado. O suicidio entre os jovens de 15 a 24 anos tem sido o dobro das taxas nacionais. O uso de armas de fogo, tanto nos homicídios como nos suicídios é bastante alto. Segundo o Departamento de Saúde do Estado, as causas que contribuem com a violência no NM são a pobreza, o racismo, a violência familiar, o uso de álcool e drogas e o desemprego.

Problemas relacionados à (7) Drogadição são freqüentes no Estado. O NM tem a mais alta taxa de mortalidade relacionada ao uso de álcool em comparação ao restante do pais. No período compreendido entre 1986 e 1990 houve uma média de 51,3 mortes por 100 mil pessoas no $\mathrm{NM}$, bem maior que a verificada na média nacional, que é de 35,7 mortes por 100 mil. O consumo de álcool diminuiu entre 1977 e 1993, porém o resultado do Behavioral Risk Factor Surveillance Survey (pesquisa estadual realizada por telefone) indica que $14 \%$ dos novo-mexicanos adultos bebem cinco ou mais doses numa única ocasião, no minimo uma vez por mês. Estima-se que 
$6 \%$ dos adultos no NM sejam álcool-dependentes. Também existem dados que mostram que o uso de álcool e drogas entre os adolescentes do Estado excede as taxas observadas nacionalmente. Dados quanto ao uso de drogas ilícitas são dificeis de obter, mas um levantamento realizado em Albuquerque revelou que $6 \%$ dos adultos usam uma ou mais substâncias ilicitas regularmente, sendo a marijuana a substância mais mencionada.

Com relação ao (7) Tabagismo, dados do Behavioral Risk Factor Surveillance Survey mostram que $22,8 \%$ dos adultos do NM são fumantes. Entre os adultos jovens de 18 a 24 anos, observou-se uma freqüência de $27 \%$ entre os homens e $26 \%$ entre as mulheres. Entre 1990 e 1994 ocorreram 10.000 mortes precoces por doenças relacionadas ao uso de tabaco no Estado do NM.

As (8) Doenças crônicas, como doenças cardíacas, diabetes e câncer, matam mais pessoas no Estado do que qualquer outro grupo de doenças. Em 1995, 25\% de todas as mortes ocorridas no NM foram decorrentes de doenças cardíacas. $\mathrm{O}$ câncer do sistema respiratório é a principal causa de morte por câncer no Estado do NM. Dados do Behavioral Risk Factor Surveillance Survey indicam que 70.000 novomexicanos têm diabetes, e este número vem subindo, pois o sobrepeso, que contribui para o acréscimo de doenças cardiacas e diabetes, vem aumentando, segundo levantamento realizado entre 1988 e 1996.

Com relação à (9) Saúde mental, aproximadamente um quarto dos adultos do NM com 18 anos ou mais (226.000 pessoas) têm algum tipo de desordem mental ou distúrbio emocional, segundo a Divisão de Comportamento em Saúde. Fatores como as relações familiares e de amizade, alcoolismo, uso de drogas, desemprego, suicídio, acidentes pessoais e morte em veículos têm um grande impacto quando se trata de saúde mental.

(10) Incapacidade ou deficiência fisica ou mental foi definida como uma situação crônica atribuível a danos físicos, mentais ou a uma combinação de ambos, que resulta em uma limitação funcional das atividades da vida diária. Estima-se que mais de 16.000 adultos no NM tenham alguma incapacidade física ou mental. $O$ foco dos serviços de saúde para pessoas com algum tipo de incapacidade seriam as clínicas comunitárias ou a atenção domiciliar. A demanda por serviços de saúde para pessoas com incapacidade é bastante grande, segundo o Departamento de Saúde do Estado, e 
há uma longa espera por devida atenção nos programas relacionados à incapacidade no Estado do NM.

Com relação ao (11) Meio ambiente, os principais problemas de saúde no Estado do NM estão relacionados à contaminação de água e alimentos, como giardíase e criptosporidiosis, bem como à contaminação de fontes de água urbanas e rurais, por arsênico e hidrocarbonetos clorados. Também são relatados casos de contaminação por chumbo em crianças.

Com relação às (12) Doenças veiculadas por animais ou insetos, duas têm grande importância no Estado, com o maior número de casos reportados quando comparados ao resto do país. Uma é a síndrome pulmonar por Hantavírus e outra é a peste, por causa do crescente número de roedores presentes no meio ambiente nos últimos anos.

\subsection{O SISTEMA de SAÚde do ESTAdo do Novo MÉXICo}

Uma outra questão que pareceu importante entender a respeito do cenário de estudo é o sistema de saúde do Estado, para o qual também se utilizou o relatório realizado pelo Departamento de Saúde do Estado do Novo México do ano 2000 (NEW MEXICO DEPARTMENT OF HEALTH, 2000a, 2000b).

O sistema de saúde do Novo México é composto de serviços que incluem atendimento de emergência médica; cuidados primários em saúde; especialidades médicas e odontologia.

Os serviços de cuidados primários incluem o diagnóstico e serviços de tratamento com médicos de clínica geral, prática de família, pediatria, ginecologia e obstetricia, medicina interna e odontologia geral.

Os serviços de saúde no Novo México são financiados por muitas organizações diferentes e incluem a medicina privada, as companhias de seguro de saúde, o Medicare, os Programas de Saúde Indigena, o Serviço de Saúde Pública dos Estados Unidos, a Administração do Hospital dos Veteranos, o Medicaid e outros programas do Estado. A Comissão de Política de Saúde do Novo México (HPC) desempenha um papel de planejamento, monitoramento e suporte técnico. 
Existem muitas barreiras bloqueando o acesso das pessoas a serviços de saúde especificos. As barreiras mais comuns incluem a pobreza; a falta de seguro de saúde; a falta de conhecimento sobre os serviços; o transporte inadequado; e as barreiras de idioma ( $40 \%$ da população do Estado é hispànica).

A pobreza no Novo México é claramente uma barreira de acesso aos serviços de saúde pela maneira como está estruturado o sistema de saúde, que é basicamente de caráter privado. Existem programas que provêem acesso para as pessoas de baixa renda, mas com muitas restrições. O Medicaid dá cobertura a crianças e mulheres grávidas com renda abaixo de uma certa porcentagem do nível de pobreza (Federal Poverty Law - FPL - que é definida como a renda mínima necessária para uma dieta adequada).

O Medicare provê cobertura para idosos e adultos com falência renal. O Plano de Seguro-Saúde das Crianças do Estado, com fundo federal, estende a cobertura para crianças que vivem em uma certa porcentagem do nível de pobreza (FPL). Os adultos, diferentemente das mulheres grávidas, só são elegiveis para Medicaid se sua renda for menor que $37 \%$ do FPL. Só para se ter uma idéia, 1 em 5 novo-mexicanos ( $22 \%$ ) vive em pobreza, comparados com os 13,2\% nos Estados Unidos (no periodo em que foi realizado o estudo, 1996 - 1998). O nível de pobreza era um salário anual de $\$ 17.050$ para uma familia composta por quatro pessoas.

$\dot{E}$ interessante ressaltar que o fato de ter um emprego não exclui os novomexicanos de viverem na pobreza. Em 1990 existiam 499.416 novo-mexicanos com idades entre 25 - 64 anos empregados na força de trabalho. Desses, 65\% eram empregados em tempo integral (35 a 50 horas por semana e $6 \%$ trabalhavam meio periodo (menos que 35 a 50 horas por semana). Dos trabalhadores em tempo integral, 4\% tinham renda baixo do FPL. Para os trabalhadores de tempo integral, eventualmente o empregador lhes paga algum tipo de seguro-saúde. Para os de tempo parcial não existe tal possibilidade. Outra coisa que contribui para que mesmo os empregados estejam abaixo do nivel de pobreza é o fato de ficarem empregados sazonalmente.

A mais alta taxa de pobreza se distribui entre os indigenas $(10 \%)$, seguidos pelos hispânicos $(6 \%)$, negros $(4 \%)$ e brancos não-hispânicos $(2.5 \%)$. 
Como resultado, alguns adultos não se qualificam para o Medicaid e não têm renda, ou a têm muito baixa, para pagar um seguro de saúde privado. A "rede de proteção" para eles inclui fundos municipais para indigentes, e também fundos de origem federal, estadual e subsidios locais para as clínicas comunitárias.

Os fundos municipais para indigentes têm critérios de elegibilidade variáveis, por exemplo, requisitos de residência e cobertura de saúde são estendidos para imigrantes legais ou pessoas sem documentos. $\mathrm{O}$ alcance da cobertura dos serviços de saúde também varia muito. Os centros de cuidados primários com base nas comunidades são publicamente subsidiados e provêem serviços sob remuneração baseada na renda do paciente. Além disso, hospitais, clínicas e médicos provêem quantias significantes de cuidados não compensados, para os quais não se tem estimativas de custo disponiveis.

Como discutido antes, a disponibilidade não significa acessibilidade, ou seja, a existência de um programa ou serviço não necessariamente significa que todo mundo que é elegivel consegue realmente utilizá-los. O Serviço de Acompanhamento de Política de Saúde (HPTS) usa dois métodos diferentes para estimar quantas pessoas não tem acesso a serviços de cuidado primário: calcula-se que $20 \%$ a $36 \%$ dos novomexicanos não têm acesso. Outra abordagem, usada pela Comissão de Política de Saúde de Novo México, são as pesquisas por telefone, que perguntam aos novomexicanos sobre cobertura de saúde, sua necessidade de serviços de saúde e se conseguiram os serviços de que precisaram.

A pesquisa realizada em 1999 pelo New Mexico Health Policy Commission (HPC) constatou que $14 \%$ dos adultos não tiveram nenhuma cobertura durante todo o ano de 1998 . Outros $7 \%$ tiveram cobertura somente durante uma parte do ano. $\mathrm{Na}$ pesquisa, "cobertura" inclui qualquer seguro de saúde, programas como Medicaid e organizações como a Administração do Serviço de Saúde Indigena e dos Veteranos. $10 \%$ estavam sem cobertura de saúde ao longo de 1998 e outras $7 \%$ tiveram cobertura só em parte do ano.

De acordo com a mesma pesquisa, entre os novo-mexicanos com cobertura em saúde, os problemas de acesso não eram raros: quase $14 \%$ das pessoas que precisaram de cuidado dental não conseguiram pagar: $25 \%$ dos que precisavam de 
serviços de saúde mental declararam que não conseguiram atendimento;. quase $12 \%$ dos que precisaram de serviços de cuidados primários também não o conseguiram.

É importante ressaltar que, no Novo México, mesmo estar empregado não significa ter acesso aos serviços de saúde: entre as pessoas que disseram que não podiam dispor de cobertura, mais de $55 \%$ estavam trabalhando em tempo integral. De fato, $12 \%$ dos adultos que estavam trabalhando em tempo integral no ano de 1998 permaneceram sem cobertura.

Em nivel nacional, o tratamento para desordens mentais permanece especialmente problemático. Outro problema apontado por estudos americanos mostram que os indigentes que precisam de tratamento podem permanecer anos sem consegui-lo ou até nunca o receberem. De fato, tais estudos revelam que pessoas com desordens mentais têm mais problemas do que as outras quanto ao acesso a qualquer cuidado médico.

No Novo México, muitas pessoas que não tem acesso a odontologia. As clínicas comunitárias subsidiadas são a rede de proteção para as pessoas não cobertas por outros sistemas, porém só $35 \%$ destas clínicas tem serviços de saúde bucal, o que evidentemente não é suficiente para dar cobertura às necessidades da população. 


\section{Capítulo 4 \\ Resultados \\ O caso da Escola de Medicina \\ da Universidade do Novo México}


Este capitulo é o resultado das observações realizadas, da análise documental, das entrevistas e das conversas informais com docentes e alunos da escola de medicina.

A pesquisadora, na condição de observadora participante, teve a oportunidade de tomar parte dos grupos de alunos denominados tutoriais em três diferentes blocos: (1) Fundamentos, (2) Musculoesquelético e (3) Gastrointestinal, Metabolismo e Nutrição, no período de agosto a dezembro de 1999. Foram 15 semanas de participação e acompanhamento dos grupos tutoriais, com reuniões realizadas duas vezes por semana e com duração de três horas, totalizando noventa horas de observação. O primeiro grupo observado tinha sete alunos e o segundo seis alunos.

Por um período de quinze semanas, foi possivel participar também das reuniões semanais do docentes para discussão dos casos. Essas reuniões tem por objetivo preparar os tutores (docentes) para facilitar as discussões nos grupos de alunos; discutir as particularidades de cada caso utilizado nos blocos; tirar dúvidas sobre o próprio caso, bem como discutir quaisquer problemas que aparecem entre os alunos ou grupos.

Dentro do Setor de Desenvolvimento Educacional do Professor, foi possível participar dos eventos relacionados à formação dos docentes da escola médica tais como: Tutor Training and Case Development Workshop: Problem-based StudentCentered Learning, realizado em outubro de 1999; Lecturing and Formal Presentation, em novembro de 1999; Options in Health Science Education Conference, em janeiro/fevereiro de 2000; e da reunião do Curriculum Development, Planning and Implementation em setembro de 2000.

Foi possivel participar também das reuniões denominadas Tutor Dialogues, realizadas mensalmente no período de setembro de 1999 a fevereiro de 2000, num total de seis. O objetivo dessas reuniões é afirmar a atualização do docentes em temas de educação e saúde.

Metade das entrevistas e o início da análise documental ocorreu parte em 1999, parte no ano 2000. 


\section{O caso da Escola de Medicina da Universidade do Novo México}

A Escola de Medicina da Universidade do Novo México teve início em 1964, com apenas 24 alunos e 15 professores, num pequeno prédio que havia sido antes uma fábrica de refrigerantes. Contava com um antigo hospital do condado e um necrotério. Ao longo dos anos foi expandindo o número de vagas assim como se ampliando as instalações.

A escola nasceu devido à necessidade premente de formar médicos para o Estado, pois havia grande dificuldade de atrair médicos e profissionais de saúde para um Estado pobre, com minúsculas cidades em meio a montanhas e com um clima semidesértico.

Inicialmente o curso tinha duração de apenas dois anos. Posteriormente foi modificado, utilizando-se um modelo considerado inovador na época, denominado Case Western Reserve Medical. Em 1968, o curso já tinha um total de quatro anos de duração, o que corresponde ao padrão observado atualmente nos cursos de medicina nos Estados Unidos. Nesse período a abordagem curricular era tradicional em sistema de disciplinas. Em meados da década de 1970, o número de alunos aumentou para 73 e o curriculo se tornou mais tradicional e menos flexível C(1) e (THE UNIVERSITY OF NEW MEXICO: SCHOOL OF MEDICINE 1989; THE UNIVERSITY OF NEW MEXICO: SCHOOL OF MEDICINE 1992).

\subsection{O currículo Paralelo: 'Currículo de Cuidados Primários em Saúde (CCPS)}

A recomposição da descrição da origem e do desenvolvimento do CCPS na Escola de Medicina da UNM baseou-se em dados de entrevistas, do primeiro capítulo do Livro Implementing problem-based medical education, editado por Arthur Kaufman (KAUFMAN 1985) que conta como foi a história da implantação do programa, e em vários artigos publicados pela equipe que participou do programa: KAUFMAN, OBENSHAIN, VOORHEES, BURROLA, CHRISTY, JACKSON, MENNIN 1980; KAUFMAN, KLEPPER, OBENSHAIN, VOORHEES, GALEY, DUBAN, MOORE-WEST, JACKSON, BENNET, WATERMAN 1982; 
KAUFMAN, MENNIN, WATERMAN, DUBAN, HANSBARGER, SILVERBLATT OBENSHAIN, KANTROWITZ, BECKER, SAMET, WIESE 1989; MENNIN e KAUFMAN 1989; SHELINE, SMALL, MCCOLLUM, GORBY, SCHUSTER, MENNIN, KAUFMAN 1990

A história desse currículo começa quando o atual diretor do Departamento de Medicina Familiar e Comunitária chegou ao NM e iniciou um curso de introdução à medicina familiar e comunitária com duas horas-aula por semana. Cada semana um professor diferente dava uma aula em sua área de especialização. Segundo KAUFMAN (1985), alguns deles eram excelentes médicos, mas sofriveis como professores. Os alunos tinham críticas ao curso, e ele mesmo, diretor do departamento, relembrou o quanto também havia criticado seu próprio curso na época. Ele sabia, pela sua própria experiência em comunidades rurais, no internato e na residência, que os problemas de saúde eram reflexo dos problemas sociais, políticos e econômicos da comunidade e sabia também que sua própria formação não o tinha preparado para esta demanda. Ele relembrou o terror que as aulas de bioquimica e fisiologia the causavam quando estudante, e considerou que o período de maior aprendizagem em sua vida tinha sido na residência e no trabalho no serviço de saúde dos indigenas. Foram dois momentos de aprendizagem vivencial em um contexto com pacientes reais e na comunidade.

O diretor do departamento dividiu suas preocupações com um pequeno grupo de docentes e profissionais de saúde que começavam a refletir sobre a forma como estava ocorrendo a educação médica nos anos pré-clínicos: tão pouco excitante, com os alunos passivos, anônimos e isolados dentro de uma sala de aula (KAUFMAN 1985).

Foi a partir dessa insatisfação que o curso foi totalmente modificado. O grupo do departamento decidiu que não haveria mais aulas tradicionais, não haveria mais aprendizagem passiva. Os alunos foram divididos em pequenos grupos e os conteúdos passaram a ser abordados na forma de discussões dos casos clínicos, o que também incluía o exame fisico. Cada estudante atendia, uma tarde por semana, em um dos centros de saúde comunitários. Os estudantes então passaram a adorar o curso. $\mathrm{O}$ ponto alto era o método: participativo, centrado no estudante e baseado em aprendizagem na comunidade. 
Um outro professor, diretor da graduação em Educação Médica, pediatra de formação, também estava insatisfeito e percebia quão limitada era sua atuação diante do poder dos departamentos, além de sentir-se frustrado ao ouvir os estudantes reclamarem do currículo, dos métodos instrucionais e do estresse que gerava o curso de medicina. Apesar de a escola ter apenas dez anos na ocasião, muito da energia já havia se esvaido. A experiência mais criativa que esse diretor vivenciara era um trabalho experimental com o Departamento de Medicina Comunitária, que treinava enfermeiras para servir em zonas rurais. A idéia era que as enfermeiras treinadas deveriam morar no local e um médico atenderia uma vez por semana naquele núcleo. Começaram com uma enfermeira e logo o programa tomou força e se expandiu pelo Estado. Para o professor, então, ficava cada vez mais claro o contraste entre a liberdade do modelo para as enfermeiras e a rigidez da educação dos médicos. E ele se perguntava o que poderia ser feito para mudar essa situação.

Os dois professores observaram outras forças que criavam demandas em relação à educação médica. Havia no momento uma discussão no Congresso americano sobre a má distribuição geográfica de médicos por especialidade. O Novo México tinha um grande problema: um terço da população encontrava-se concentrada em três cidades, as maiores, cujos serviços já não eram suficientes para cobrir as necessidades da própria população residente, muito menos do restante da população dispersa no Estado, em pequenos núcleos, sem serviços de saúde. A má distribuição de médicos era tão intensa que se tomou um problema legislativo. Então os dois professores decidiram escrever uma proposta de modificação curricular na formação do médico, que levasse em conta a realidade social e econômica do Estado. O diretor da Escola de Medicina havia concordado com a implantação do currículo, mas não ia além disso, não dava grande apoio. A formação de um grupo nuclear de planejamento foi a estratégia para a implantação do curriculo (KAUFMAN, KLEPPER, OBENSHAIN, VOORHEES, GALEY, DUBAN, MOORE-WEST, JACKSON, BENNET, WATERMAN 1982; KAUFMAN 1985).

Em 1977, o diretor do Departamento de Medicina Familiar e Comunitária e o diretor da graduação em educação médica mais alguns outros das ciências básicas, de anatomia e de fisiologia, e outros das ciências clínicas, propuseram à Escola de Medicina um currículo experimental ao qual, num primeiro momento, o corpo de 
professores da escola foi favorável. Para colocar o projeto em prática, no entanto, precisavam de recursos financeiros, e a proposta foi enviada a várias fundações sem sucesso. Na realidade, era uma pequena escola de um Estado rural que estava solicitando recursos e politicamente não tinha o mesmo apelo que as outras grandes e famosas universidades americanas. Finalmente o diretor do Departamento de Medicina Familiar e Comunitária visitou e apresentou pessoalmente a proposta à Fundação Kellogg, que se dispôs a apoiar o projeto (KAUFMAN, 1985).

Assim, em 1979, teve início um currículo paralelo ao tradicional. O currículo inovador, conhecido como CCPS - Currículo de Cuidados primários em Saúde - foi oferecido como uma alternativa ao currículo tradicional nos dois anos iniciais, a fim de encorajar os estudantes a escolher uma carreira médica em cuidados primários em saúde. No terceiro ano os estudantes do CCPS se juntavam aos outros do currículo tradicional, no estágio profissionalizante.

Os primeiros estudantes começaram em 1979, o último grupo foi graduado em 1996, e o programa envolvia os alunos nos dois primeiros anos. No principio o curriculo teve como modelo o da McMaster e depois nós mudamos significativamente [o currículo] para uma experiência de cuidados primários em zona rural. Eu penso que este programa proporcionava uma experiência real da prática médica, o que os estudantes [num currículo tradicional] somente teriam contato muito mais tarde na sua formação

O objetivo principal do programa era formar médicos em cuidados primários em saúde que trabalhassem em zonas rurais deficientes em serviços de saúde e que também tivessem a compreensão integral dos problemas e das necessidades de saúde da comunidade. Outro grande objetivo era a automotivação e o estímulo ao hábito de estudar com autonomia e independência ao longo de toda a vida (CORTES, KAUFMAN, SANCHEZ, BENNET, ORTIZ-HUERTA, MARTINEZ-BURROLA, ALONSO E DURAZO 1985; KAUFMAN, MENNIN, WATERMAN, DUBAN, HANSBARGER, SILVERBLATT, OBENSHAIN, KANTROWITZ, BECKER, SAMET, WIESE 1989; KAUFMAN 1990). Desde o início o programa foi altamente orientado para a comunidade e para responder às necessidades do Estado. 
A inovação começou por causa da necessidade do Estado, começou por causa da crise em nosso Estado. Os médicos de cuidados primários não eram suficientes nas áreas rurais. Eu penso que qualquer inovação, para se sustentar, tem que encontrar um movimento importante na sociedade. Não pode ser só curiosidade filosófica ou intelectual. Isso normalmente não sustenta a mudança, porque as forças contrárias à ela são tantas que a inovação logo seria esmagada. Tem que existir um movimento na sociedade que seja um apoio social a uma necessidade importante, para se aliar. Isso ajudará a dar sustentação à mudança a longo prazo. Esta foi a gênesis da idéia

Este Discurso do Sujeito Coletivo ilustra como o momento histórico e político facilitou a implantação do Currículo de Cuidados primários em Saúde (CCPS), e como ele foi idealizado.

No CCPS, a escolha da metodologia da Aprendizagem Baseada em Problemas (ABP) não foi estabelecida a priori. Ela surgiu com base no interesse dos idealizadores de colocarem os estudantes precocemente na comunidade, pela impossibilidade de reunir os alunos quando eles estavam em estágio, e porque acreditavam que era possível aprender de maneira mais ativa. Os docentes se expressaram da seguinte forma sobre a origem da ABP:

A utilização da ABP veio depois, para resolver um problema. Se os estudantes logo no inicio iam para a comunidade por longos periodos de tempo, como eles poderiam estudar? Como nós não podiamos ensinar ciência básica e clínica a distancia, a ABP da McMaster parecia ser um caminho interessante para ensinar os estudantes a aprender por si mesmos. Nesse curriculo paralelo não havia aulas. O currículo era 100\% Aprendizagem Baseada em Problemas, nenhuma aula. Só um grupo pequeno aprendendo em sessões realizadas três vezes por semana. Existiam muito poucas sessões de laboratório, onde os alunos poderiam ir a um laboratório de fisiologia ou algo assim, mas era basicamente um grupo pequeno com aprendizagem aluno-centrada.

No CCPS, não havia aulas tradicionais, havia o trabalho em pequenos grupos com sessões tutoriais a partir de um problema clínico, metodologia esta pioneiramente utilizada na McMaster University. Os estudantes aprendiam através de estudo e discussão de casos clínicos especialmente preparados (THE UNIVERSITY OF NEW MEXICO: SCHOOL OF MEDICINE 1989). O currículo foi planejado para levar os estudantes durante seus anos pré-clínicos a cenários rurais de cuidados primários em 
saúde e também a comunidades urbanas sem acesso a serviços de saúde. Os professores descreveram em linhas gerais como o processo se desenvolveu:

Com o desenvolvimento do programa Tivemos a oportunidade de colocar os estudantes em estágio na comunidade por um periodo de 16 semanas. Eles ficavam com os médicos na comunidade, em uma área rural, e tinham um relacionamento muito especial. Havia muito interesse na comunidade, nos aspectos biológicos e nos comportamentais. A característica impar era a experiencia de cuidado primário rural no final do primeiro ano médico. Esta prática, do ponto de vista profissional, proporcionava uma experiência vivencial da medicina e eles podiam avaliar as necessidades médicas e o trabalho do médico na área rural, e isso dava a eles a percepção do quanto eles precisavam preparar-se...

Ao comentar como era o curriculo do CCPS, os professores já iam delineando o tripé que no futuro iria nortear o curriculo atual, que busca discutir com os alunos os casos nas dimensões biológicas, comportamentais e populacionais. No currículo atual, nos grupos de tutoria de ABP, cada caso que os alunos discutem, eles tem que faze-lo nos três aspectos: biológico, comportamental e populacional. No trabalho de campo foi possivel constatar que o CCPS era composto por dois aspectos fundamentais: a prática, através do estágio clínico precoce, e a metodologia de aprendizagem ativa.

O docente tinha a função de ser um facilitador da aprendizagem (CORTES, KAUFMAN, SANCHEZ, BENNET, ORTIZ-HUERTA, MARTINEZ-BURROLA, ALONSO e DURAZO 1985). O pressuposto era que o estudante tivesse um estímulo natural ao aprendizado a partir de um problema real. A idéia era integrar as ciências básicas e clínicas com o desafio da auto-aprendizagem. $O$ curriculo buscava também integrar as ciências básicas e as ciências clínicas, numa inovação que confrontava a tradicional proteção territorial dos departamentos (KAUFMAN, MENNIN, WATERMAN, DUBAN, HANSBARGER, SILVERBLATT, OBENSHAIN, KANTROWITZ, BECKER, SAMET, WIESE 1989).

No primeiro ano o currículo experimental contou com dez alunos, aumentando progressivamente para quinze no ano seguinte e vinte nos demais anos, para cada 73 estudantes admitidos na Escola de Medicina. O currículo tradicional era composto por 
dois anos pré-clínicos, com ênfase nas ciências básicas, e dois anos de estágio profissionalizante (KAUFMAN 1985).

Com o desenvolvimento de dois diferentes curriculos na universidade começaram a aparecer os problemas, tanto entre os docentes como entre os alunos. Houve uma cisão entre os docentes que trabalhavam num currículo e os que trabalhavam em outro, pois eram currículos muito diferentes. Havia também uns poucos docentes que trabalhavam nos dois currículos. No início, a existência de um programa paralelo não acarretava muita resistência, devido ao pequeno número de alunos e dos recursos limitados. Quando ambos aumentaram, os recursos destinados ao programa e o número de alunos, ganhou também a visibilidade, e consequentemente os conflitos entre os docentes.

No inicio do CCPS, com a pressão do Estado e a legislação a favor, não houve protesto, pois o diretor e a legislação eram favoráveis, o programa era pequeno e contava com fundos externos, e não preocupava ninguém. Havia gente que não gostava, mas não se importava, pois ninguém estava solicitando mudanças, parte dos professores podia ensinar da maneira tradicional. Os problemas começaram quando o grupo de estudantes cresceu de dez para vinte alunos, de uma turma de setenta e três. Além do suporte externo, mais pessoas de dentro começaram a trabalhar com o programa e era prazeroso trabalhar com os alunos dessa maneira. As criticas vinham de parte dos que estavam no campus... Nós fomos criando um grande número de preceptores e professores na comunidade, trabalhando bem com os legisladores nas suas comunidades.

O novo currículo acarretava um grande entusiasmo por parte dos alunos e dos professores envolvidos. Os relatos dos professores e a emoção demonstrada nas entrevistas refletem isso:

O currículo de cuidados primários foi uma experiencia maravilhosa, a característica ímpar era a experiencia de cuidado primário rural no final do primeiro ano médico. Do ponto de vista profissional, proporcionava aos alunos uma experiência real de ver o que era a medicina, e eles podiam avaliar o quanto um médico em área rural deveria saber, o que dava a eles a idéia do quanto eles precisavam estudar. Era um pequeno grupo de alunos, era como uma familia. A experiência era muito intensa em relação ao método, principalmente para os tutores de medicina familiar e de saúde pública. Aprender e ensinar medicina podia ser divertido e prazeroso. Eu fiquei seduzido por aquela idéia de alunos e docentes aprenderem juntos. Então eu 
achei que era prazeroso e eu praticamente tutorei todos os anos no currículo de CCPS. As coisas iam bem, mas estavam muito desconectadas entre o que acontecia no campus e o que acontecia na comunidade. Quando então apareceu uma outra fonte de recursos começou uma grande batalha...

Convém mencionar dois aspectos importantes no CCPS: tanto os docentes que trabalharam nele, como os alunos, tinham um perfil diferenciado, o que é corroborado pelo depoimento dos entrevistados:

O grupo de docentes era selecionado e eles eram realmente dedicados àquele modo de aprender e eram muito, muito bons. $O$ grupo de docentes era muito pequeno e estava muito comprometido. Havia comunicação, as pessoas podiam conversar, eu quero dizer, existia aquela química das pessoas se tornarem amigas além de colegas, e como as pessoas eram amigas, muitos dos assuntos que surgem agora não aconteciam. No seminário de treinamento dos tutores que foi realizado antes de nós começarmos o CCPS, eu fiquei realmente impressionado pela habilidade dos alunos para aprenderem e no quanto eu adquiri com a experiência de trabalhar com os alunos, não só no nivel pessoal, mas também no saber que eu adquiri sobre medicina e outras áreas da ciência.

Já na admissão dos estudantes para a Escola de Medicina, eles podiam escolher entre o currículo tradicional e o experimental. No experimental havia então uma nova seleção aleatória dos estudantes. Os estudantes que escolhiam entrar no CCPS tinham um perfil diferenciado:

Os alunos também eram selecionados, pois escolhiam aprender daquela forma. Era um grupo muito especial, os estudantes aprendendo em grupos pequenos, com um tutor, que era um facilitador da experiencia. Os estudantes eram muito entusiasmados com o currículo. Foi um tempo de muito entusiasmo, de educação, era um tempo muito especial. Os alunos que estudaram neste programa claramente queriam estar lá, em geral os alunos eram ligeiramente mais velhos, talvez tivessem mais experiência de vida.

Outra oportunidade de expansão das idéias oriundas do currículo paralelo surgiu em 1987. A Escola de Medicina recebeu outra subvenção da Rockfeller Foundation e da Pew Charitable Trusts, num programa denominado Health of the Public (HOP), para desenvolver um modelo inovador em educação clínica que propugnava ensinar os estudantes a interpretar e tratar problemas de individuos, família e comunidade nos seus contextos sociais. Esse programa tinha como objetivo 
a utilização de protocolos de promoção de saúde e prevenção de doenças em indivíduos e grupos, o trabalho em equipe multidisciplinar, a utilização eficiente de recursos comunitários, entre outras questões (THE UNIVERSITY OF NEW MEXICO 1989; SHELINE, SMALL, MCCOLLUM, GORBY, SCHUSTER, MENNIN, KAUFMAN 1990).

Somente em 1992 surgiu a oportunidade de fundir os dois currículos. A experiência do currículo paralelo deixou marcas nos seus participantes, tanto nos docentes como nos estudantes, que atualmente ocupam cargos de direção no Departamento de Saúde Pública. Nas entrevistas observou-se que os relatos vinham sempre carregados de emoção. Por outro lado, apesar dos esforços para trabalharem juntos no mesmo currículo, até os dias de hoje existe ainda uma cisão entre os dois grupos na Escola de Medicina.

\subsection{Currículo atual}

O currículo da Escola de Medicina da UNM foi totalmente remodelado a partir de 1992, quando se decidiu finalmente fundir os dois curriculos existentes, utilizando uma subvenção da Robert Wood Johnson Foundation (THE UNIVERSITY OF NEW MEXICO 1991; MENNIN e KRACKOV 1998):

Robert Wood Johnson é uma fundação nacional que deu o equivalente a 4 milhões de dólares a oito escolas médicas que estavam preocupadas com o desenvolvimento de novas formas de ensinar, como também no desenvolvimento de médicos mais humanistas.

A meta dos docentes inicialmente era trazer o que havia de melhor em ambos os currículos. Assim se manifestaram os entrevistados a respeito da junção:

A meta foi juntar os dois [curriculos], trazendo o melhor de ambos, eu não estou certo se conseguimos o melhor de ambos, mas houve um esforço para integrar as ciências básicas com as clínicas. Uma das metas, certamente, do novo curriculo era tentar fazer os alunos mais envolvidos em sua própria aprendizagem e eu penso que isso realmente ajuda muito. [o curriculo] é idealizado para os estudantes pensarem um pouco mais, o outro curriculo era principalmente baseado em aulas, então era o professor falando uma matéria para os alunos, apresentando informações. A diferença é que agora existem 
três dimensões no currículo: o biológico, o epidemiológico (população) e o comportamento, esses dois caem na arena da cultura.

Segundo o depoimento de um entrevistado, houve um erro de avaliação por parte dos idealizadores, por não terem tentado realizar a junção anteriormente. Passaram-se aproximadamente quinze anos até a oportunidade de junção. Ou seja, o CCPS foi um projeto-piloto que durou longos anos, tinha alunos e professores selecionados, mas não foi eficiente para preparar outros docentes para sua ampliação e generalização:

Nós tivemos os cursos paralelos. Um curso tradicional para 53 alunos e um curso de Aprendizagem Baseada em Problemas para 20 alunos. O que mudou é que nós tivemos um curso principal, o curso tradicional onde todos os docentes ensinavam e só o CCPS era voluntário. Então, só mais ou menos 100 docentes, talvez uma quarta parte, $25 \%$ de docentes participavam em Aprendizagem Baseada em Problemas. [com a fusão] o que mudou é que agora todos os docentes estão envolvidos em Aprendizagem Baseada em Problemas. Antes a ABP era só nos primeiros dois anos, depois da mudança ficou nos três primeiros anos. Então ficou mais longo. Antes da mudança todos os alunos iam às comunidades rurais por seis semanas. Depois da mudança, de oito a doze semanas. Também antes da mudança nós não Tivemos avaliação baseada na performance (SPA), através de todos os quatro anos. Nós não tínhamos uma Avaliação do Progresso do Estudante (Student Progress Assessment).

Com a fusão dos dois currículos e sua ampliação para toda a Escola de Medicina, não só os professores do currículo tradicional tiveram que se adaptar à nova forma de trabalho, como também se tornou necessário saber previamente os casos clínicos de cada área, juntarem-se semanalmente para discutir e, portanto, participar mais ativamente da educação dos estudantes. Por outro lado, ao mesmo tempo que se pôde captar o que havia de melhor em cada curriculo, também foram incorporados alguns problemas. Com a mudança curricular, os docentes do currículo tradicional tiveram que escrever casos, integrando os sistemas orgânicos, as ciências básicas e as clínicas. Na prática, nem todos se envolveram na reforma curricular, simplesmente deram um formato de caso ao conteúdo ensinado em suas disciplinas:

Quando se modificou todo o sistema há seis anos, então tiveram que escrever casos, os famosos casos do currículo. Os tradicionalistas só mudaram o nome 
e não a sua forma de pensar, muitos dos casos de currículo são lobos com outro nome, é a mesma coisa.

A junção dos dois curriculos trouxe novamente à tona os problemas, as resistências e as críticas. Constataram-se perspectivas diferentes quanto aos aspectos positivos e negativos do novo currículo. Aqueles que estavam previamente envolvidos no CCPS sentiram que perderam o controle que antes tinham do currículo. Consideraram o currículo menos participativo em relação aos alunos, mais centrado no professor que no aluno. Por outro lado, a maioria dos entrevistados viu como um ponto positivo a inclusão de todos os docentes na nova forma de trabalho e, ainda, a possibilidade de dedicar mais tempo à residência e aos estágios práticos do currículo:

Algumas coisas foram perdidas, mas outras coisas foram ganhas, globalmente foi um ganho positivo. Existia uma preocupação pela administração pelo custo de dois cursos com curriculos separados, existia alguma pressão da faculdade para juntar os cursos num só. Na fusão [o currículo] se tornou muito centralizado no professor, os alunos não têm escolha no curriculo, eles fazem todas as coisas, mas não têm controle, porque agora você adicionou os professores do curso convencional que era muito centrado no professor. Então eu penso que perdemos, por outro lado... Agora não temos o controle do curriculo como antes. Howve a perda da característica experimental e a proximidade que os docentes tinham no CCPS, porém agora todos os docentes estão incluidos. Quando nós integramos o currículo, eu comecei a participar só naquela parte de Aprendizagem Baseada em Problemas que era relacionada 'a minha área de especialização e se tornou muito menos prazeroso.

Um dos aspectos positivos levantados por aqueles que estão mais envolvidos na melhoria do currículo é que agora eles têm mais tempo para se dedicar a implementar outras inovações em educação na área médica. O outro foi o aumento do envolvimento dos docentes que só trabalhavam no currículo tradicional:

Por outro lado, agora você tem atividades de comunidade ao longo /do curriculo] da escola médica e a outra coisa que aconteceu é que você começa a olhar para inovações em educação, freqüentemente nós começamos no primeiro ano ou no segundo ano médico, você não tem nenhuma inovação que acontece nos anos clínicos, na residência, ou na prática. Então com a fusão [dos currículos] estamos liberados então para continuar as inovações ao longo da educação. [o currículo antigo] era realmente um currículo baseado em aulas, então quando o novo curriculo foi posto no lugar eu me tornei 
muito mais envolvido, eu me tornei coordenador de bloco em doenças infecciosas e eu também entrei em tutoriais e em aula.

O novo curriculo (implantado a partir de 1993) estabeleceu como objetivos formais graduar médicos: (1) com habilidade e compaixão para tratar pacientes, famílias e comunidade; (2) com responsabilidade pelo próprio e contínuo aprendizado; (3) com habilidade de definir problemas e formular questões: e (4) com uma ampla perspectiva da importância da biologia humana, do comportamento, do meio ambiente, do meio cultural e social da saúde dos indivíduos e da população

\section{(UNIVERSITY OF NEW MEXICO. HEALTH SCIENCE CENTER s/d (a).}

Do ponto de vista dos docentes, parece existirem diferentes perspectivas com relação aos objetivos estabelecidos pela escola, com maior ou menor amplitude. Alguns com a idéia de formar médicos para as necessidades do Estado ou para outros lugares, outros com uma visão mais acadêmica de formar docentes e pesquisadores:

Alguns docentes vêem os objetivos de nossa escola médica principalmente em termos de tratar a saude e cuidar das necessidades do Estado, provendo doutores de cuidados primários; outras pessoas têm uma visão maior, que nossa meta está além, prover algum doutor em medicina, Ph.D. para a escola médica e prover alguém que pode querer sair e ir aonde quiser ou fazer pesquisa que sirva ao nosso Estado.

Quando questionados sobre a relação existente entre as necessidades de saúde da comunidade e o currículo, observou-se que há dificuldades em estabelecer as necessidades de saúde da população como um aspecto fundamental do currículo. Por outro lado, há docentes que demonstraram certa preocupação com esta questão:

Eu não penso que esta relação está tratada formalmente no curriculo, e eu não penso que possa ser, você pode formar médicos que se preocupam com estes problemas. Isto é o ponto critico, se vocé formar um médico que olha somente para os cuidados de saúde em uma perspectiva clínica ou de hospital, estes problemas nunca serão tratados. Eu penso que mutas pessoas vêem isto como algo que é muito importante, mas é dificil projetar um currículo que realmente dramatize isso para os alunos, é uma coisa muito dificil de fazer. Os médicos tendem a ser orientados a tratar de um particular paciente em lugar de lidar com população e preocupações com a comunidade. Alguns fazem isto muito bem, mas é uma tarefa dificil para a escola médica. Nós incorporamos em nossa Fase I aspectos relativos à população, e eu penso que isso legitima as ciências da população como sendo uma parte cientificamente 
válida do curriculo, em lugar de banir os problemas de saúde da população e saúde pública para uma parte subordinada da medicina, como eu penso que acontece freqüentemente nos curriculos tradicionais e que certamente tem sido nossa meta incorporar isto no saber básico, infelizmente eu não acho que nós sempre fazemos isto muito bem.

Embora esteja estabelecido no currículo a incorporação das perspectivas populacionais e comportamentais, além das biológicas, na Fase I, ainda existem dificuldades para a incorporação desses assuntos por parte de alguns docentes.

Com a mudança curricular realizada em 1993 passaram a existir dois comitês responsáveis pela educação médica. O Comitê do Currículo, é responsável pela política educacional, e o Grupo de Integração, que tem a função de implementar e monitorar o currículo (OBENSHAIN e MENNIN 2000).

\subsubsection{OrganizaÇão CURRICUlar}

Atualmente o currículo proposto pela Escola de Medicina é composto de quatro anos, e é baseado em sistemas orgânicos, incluindo considerações sobre biologia normal e anormal, buscando a integração das ciências básicas e clínicas nas perspectivas biológica, comportamental e populacional, enfatizando os cuidados primários e terciários de saúde e as experiências comunitárias urbano-rurais (anexo 4).

Para alguns professores, a junção dos currículos trouxe a possibilidade de envolvimento e participação no ensino:

O curriculo antigo era principalmente um curriculo baseado em aulas, eu era principalmente envolvido no primeiro e no segundo ano e realmente envolvido em dar aulas, em laboratório de microbiologia, e fazendo exames, escrevendo artigos. Então, quando o novo curriculo foi posto no lugar que eu me tornei muito mais envolvido, eu me tornei coordenador de bloco em doenças infecciosas e eu também entrei em tutoriais e em aulas.

Do ponto de vista pedagógico, trata-se de um currículo misto, com aulas tradicionais e tutoriais de pequenos grupos de estudantes e atividades em laboratório (anexo 5). Para a realização da mudança, os docentes dos dois curriculos tiveram que abrir mão de aspectos de interesse especifico. $O$ acordo realizado foi ter um currículo 
misto:

O currículo atual é baseado em um hibrido, uma mistura de Aprendizagem Baseada em Problema e o currículo tradicional. Nós temos conferências, laboratórios e sessões de revisão. Organizamos o curriculo com base nos sistemas orgânicos, houve um esforço para integrar as ciências básicas com as clínicas.

A percepção varia de acordo com a origem dos docentes. Os docentes provenientes do currículo paralelo acharam que perderam uma série de características importantes no processo de ensino-aprendizagem, enquanto os do currículo tradicional consideraram que há algo novo, flexível, mais aberto. Há ainda os que acharam que nada mudou:

O curriculo foi pensado para uma aprendizagem mais ativa e para fazer uma experiência educacional mais interessante para os alunos. Os alunos no novo currículo têm tutoriais que eles não tinham antes e menos tempo para aulas.

O principal objetivo da mudança era fazer uma aprendizagem mais ativa, com maior participação dos estudantes:

O objetivo é tentar fazer os alunos pensarem mais por si próprios, e por causa dos tutoriais eles têm que pensar mais sobre os casos, eles têm que levantar hipóteses para os problemas, lêm que perguntar os assuntos que não entendem e então têm que procurar e achar as informações. Tentar fazer os alunos mais envolvidos em sua própria aprendizagem e pensarem um pouco mais. Em grupos pequenos eles aprendem muito melhor e gostam muito mais. No novo currículo nós ainda temos um pouco de aula, mas mais em uma base de resumos, tentando estabelecer tópicos mais abrangentes e então os alunos tentam aprender a matéria com maior profundidade. Os alunos aprendem através de Aprendizagem Baseada em Problemas, em pequeno grupo, tem contato clínico precoce e tendem a escolher especialidades de cuidados primários em maior número e a evidência mostra que eles tendem a ficar mais no Estado do Novo México.

O currículo está organizado em três fases, com diferentes blocos em cada uma.

A Fase I tem duração de dezoito meses e compreende, no período da manhã, os tutoriais, as aulas, as atividades de laboratório e o desenvolvimento de habilidades clínicas. No período da tarde, desde o primeiro ano, ainda na Fase I, os estudantes têm, uma vez por semana, aprendizagem de atividades clínicas de atenção individual 
e uma hora e meia de aprendizagem em medicina de familia, e o restante do tempo livre para estudar e pesquisar (THE UNIVERSITY OF NEW MEXICO: TEACHER \& EDUCATION DEVELOPMENT 1996; THE UNIVERSITY OF NEW MEXICO: INSTRUCTORS HANDBOOK PHASE I 2000-01).

Os estudantes são incluidos desde o primeiro ano no atendimento clínico, com o objetivo de desenvolverem habilidades clínicas e terem oportunidade de integrar os princípios das ciências básicas com a prática. A prática vai dar base aos casos trabalhados nos tutoriais, como também para a elaboração de um projeto de pesquisa que é requerido a todos os estudantes, no final do curso de graduação.

No primeiro semestre eles aprendem a anamnese e a realizar o exame físico, ao mesmo tempo que desenvolvem habilidades de intervenção. Os estudantes são treinados por médicos generalistas a entrevistar pacientes e realizar um screening sobre o exame fisico. Eles começam treinando entre eles mesmos e depois entrevistam pacientes voluntários em clínicas ou casas de saúde com supervisão de um médico generalista.

A partir do segundo semestre (ainda na Fase I), os estudantes vão para consultórios médicos comunitários na cidade ou na própria universidade um período e meio por semana, quando continuam a aprender a anamnese e entrevista em clínicas de seguimento ou de cuidados primários da universidade sob a supervisão de um professor. Existe também a possibilidade de o aluno ficar com um médico em consultório privado - este médico um Professor-Assistente voluntário, funciona como um preceptor de alunos. Os estudantes fazem a anamnese, apresentam a história ao seu preceptor, que então examina o paciente junto com o aluno. Aos estudantes cabe levantar suas questões de aprendizagem (Learning issues), ou seja, identificar os aspectos que necessitam aprender mais e, então, pesquisar e estudar por conta própria.

No final do primeiro ano, todos os estudantes têm um estágio supervisionado (PIE - Practical Immersion Experience) de 4 a 12 semanas, em um cenário de cuidados primários em saúde. Os estudantes podem eleger ficar 4,8 ou 12 semanas em estágio. Quando o periodo escolhido é menor que 12 semanas, os estudantes têm que cumprir o restante do tempo na universidade para a realização de um projeto de pesquisa. Atualmente $2 / 3$ dos estudantes optam por ficar em cenários comunitários. 
Existem aproximadamente 400 diferentes locais de estágio em todo o Estado do NM, dos quais participam o staff da escola (anexo 6)

Um dos reais ganhos da Escola de Medicina com a reforma curricular foi o aumento do tempo disponivel: para o aluno, em relação às atividades práticas, e para os professores, maior tempo para a pesquisa, o atendimento clínico e mais envolvimento com o ensino médico.

A introdução do novo curriculo permitiu maior experiência, além das conferências, e isso foi coordenado com a introdução da $A B P$ e o novo currículo, com outras experiências que eram voltadas para a comunidade: o PIE [Practical Immersion Experience] e preceptoria. Tudo isso permite reconhecer a necessidade de ter tempo para fazer coisas diferentes do que somente a aprendizagem de livro. Outro fator importante é que a introdução da ABP, nos ajudou a conseguir mais docentes trabalhando em conjunto, mais tempo para os alunos irem mais cedo na comunidade, e mais tempo para conversarmos sobre necessidades de saúde da comunidade. Colocar os alunos nas cidades menores do Estado realmente permite que eles vejam os problemas e espero que os ajude a agir no futuro, tentando beneficiar as pessoas do Estado.

Normalmente o estágio de imersão acontece em uma das pequenas cidades do NM, sob a supervisão de um Professor-Assistente afiliado (existem mais de trezentos atualmente, são médicos voluntários que gostam de ensinar estudantes). $O$ aluno permanece o período de tempo escolhido com esse médico e precisa fazer um diário dos pacientes atendidos e das questões de aprendizagem. Através do computador, realiza as pesquisas necessárias para sua aprendizagem e por Email solicita à biblioteca os artigos que necessita. A cada quatro ou seis semanas recebe a visita de um professor da Escola de Medicina, que o entrevista o estudante e ao preceptor, individualmente e em conjunto, e também observa o atendimento a pacientes, e todos discutem suas observações. Durante este estágio, o estudante também tem que retornar à universidade para a realização de um exame oral e escrito sobre o exame físico e a anamnese e as questões de aprendizagem (THE UNIVERSITY OF NEW MEXICO: INSTRUCTORS HANDBOOK PHASE 1 2000-01).

Nós tentamos ter certeza de que os alunos estão saindo para a prática no Estado para ver os problemas como alcoolismo, diabetes e falta de acesso aos cuidado em saúde. Penso que só vivenciando, vendo onde os problemas 
estão, os alunos realmente se familiarizarão com os pacientes de uma cidade pequena. Realmente [a prática clínical ajuda os estudantes a aprenderem sobre isto. E, então, eventualmente eles irão querer voltar e praticar naquelas áreas como profissionais.

A Fase II, com duração de 12 meses (dois semestres), começa com rotação em diferentes cenários clínicos em que há correlação formal com os tópicos das ciências básicas. Essa fase tem por objetivos integrar verticalmente os sistemas orgânicos e horizontalmente a clínica através dos seus departamentos, como também aumentar a habilidade de auto-aprendizagem e de atendimento clínico iniciado na fase anterior.

Os estágios são realizados em três diferentes caminhos: a) medicina/cirurgia, b) medicina familiar/pediatria, c) psiquiatria/neurologia e especialidades cirúrgicas.

Também nessa fase os estudantes têm o tempo dividido entre o trabalho clínico, aulas, laboratórios, tutoriais e o tempo semanal programado para estudar e integrar as informações.

A Fase III, com 18 meses de duração (três semestres), está estruturada como uma experiência educacional que servirá de ponte entre a escola médica e a residência.

Os estudantes estão envolvidos na maior parte do tempo em estágios clínicos com rotação em disciplinas eletivas (oferecidas pelos departamentos), e devem entregar um projeto ou realizar uma pesquisa relacionada às atividades feitas ao final dessa fase.

A ênfase é a aprendizagem através da prática. Os estudantes têm a responsabilidade de cuidar diretamente de pacientes em ambulatórios e revisar seu aprendizado para superar suas deficiências em ciências básicas e clínicas. Cada estudante conta com um mentor, que auxilia tanto nas questões de aprendizagem como na escolha das disciplinas eletivas para a futura carreira. 


\subsubsection{Metodologia de ensino na Escola de Medicina da UNM}

A metodologia empregada na Escola de Medicina é descrita como mista, compreendendo aulas expositivas, Problem-Based Learned ou Aprendizagem Baseada em Problemas, laboratório e desenvolvimento de habilidades clínicas.

O objetivo de utilizar diferentes técnicas educativas é o de estimular a autoaprendizagem de maneira duradoura, bem como o hábito da pesquisa e o treinamento para falar em público

As considerações que os professores fizeram da metodologia são bastante significativas. Primeiro, a percepção de como os alunos vivenciam a $\mathrm{ABP}$, já que, na maioria das vezes, eles estudaram em escolas tradicionais:

No inicio os alunos ficam apreensivos sobre a ABP, e a razão é que eles não foram treinados para isto, eles não sabem o que é, eles foram treinados no secundário e no bacharelado para serem os recipientes passivos dos professores da academia. Eles se sentam, escutam e tomam notas e então regurgitam para a prova. É nisso que eles são treinados e é nisso que eles se sentem confortáveis. Todos os alunos que estão aqui eram bem sucedidos fazendo isto e agora eles estão em uma situação diferente. Aqui eles são apresentados a um problema, e eles não são apresentados a um rol de leitura, eles são informados que têm que identificar que assuntos de ciência básica estão envolvidos, eles não recebem uma lista de perguntas para estudar no exame final.

A ABP é um método de aprendizagem que tem início quando os alunos são apresentados a um problema (caso), seguido por um processo de investigação centrado no aluno. È desenvolvido através dos grupos de tutoriais. Os tutoriais têm como objetivo de aprendizagem desenvolver nos estudantes habilidades de autoaprendizagem, de ensinar, apresentar e ouvir criticamente, desenvolver habilidades de trabalhar em grupo, integrar conhecimentos novos com preexistentes, desenvolver habilidades de auto-avaliação e avaliação dos outros membros do grupo, senso de descoberta na aprendizagem, promover aprendizagem em contexto, aumentar habilidades de questionamento, ajudar os estudantes a descobrir os limites do conhecimento e diminuir o intervalo entre a aprendizagem da clínica e das ciências básicas, estimular os alunos a se preparar e falar com clareza e desembaraço diante dos colegas. 
A sala dos tutoriais é equipada com um computador, uma mesa de exame clínico, um aparelho para leitura de RX, uma pia e uma mesa grande em torno da qual os alunos se sentam. No computador encontram-se resultados de exames laboratoriais complementares, lâminas de histologia ou outros materiais relacionadas ao caso.

As sessões dos tutoriais acontecem todas as segundas e quintas-feiras. No inicio da semana os alunos recebem um caso novo para discutir, pesquisar, organizar e então apresentar o produto de seu trabalho na quinta-feira.

Os grupos são acompanhados de um tutor-facilitador, que é um docente de uma cadeira básica ou de clinica. A cada semana, um dos alunos também tem o papel de facilitador, ou seja, é o responsável por coordenar a sessão. Nesse papel ele deve delimitar o tempo de discussão, fazer a sintese dos assuntos discutidos, estimulando e anotando os principais topicos de aprendizagem (Learning issues) que vão sendo levantados pelos colegas durante o transcorrer da sessão. Esses tópicos de aprendizagem são as questões para as quais os alunos não têm resposta, e que irão se constituir nos temas a serem pesquisados por eles antes da próxima sessão. Em geral o grupo utiliza duas sessões por caso. Os problemas são casos clínicos significativos, que representam situações prototípicas importantes, apropriadas para o nivel de aprendizagem do estudante. O caso é construído de forma que os alunos explorem o que já sabem e o que precisam aprender a fim de avançar na compreensão do problema.

Os tutores utilizam diferentes técnicas nos casos para facilitar a discussão e ajudar os alunos a desvendarem o caso, algumas vezes subdividem o grupo para discutir aspectos do caso, ou apresentam as radiografias relacionadas ao caso, ou pedem que algum aluno faça uma sintese do que foi discutido.

O caso começa com informações curtas e simples, de modo que os estudantes vão discutindo. A cada página eles vão recebendo informações mais complexas acerca dos sintomas ou, por exemplo, dos exames que foram pedidos, a história familiar do paciente, sua ocupação e outros detalhes relevantes. Os estudantes discutem a partir dos conhecimentos que já têm e tentam responder às questões de complexidade crescente que, algumas vezes, permeiam o caso. Esse processo tem por finalidade levar o aluno a construir seu conhecimento, integrando as ciências básicas e clínicas. O caso está estruturado como um disparador para facilitar o raciocínio, a 
revisão de conhecimentos anteriores nas diferentes áreas e também para identificar aspectos que não fazem parte do conhecimento prévio do aluno (anexo 7).

Conforme a discussão avança, os alunos vão anotando os conteúdos que devem ser pesquisados com maior profundidade. Esses tópicos são transformados em questões (Learning issues) que serão então objeto de pesquisa dos alunos. Das questões de aprendizagem, geralmente 3 ou 5 das mais amplas são selecionadas pelos estudantes para serem aprofundadas por todos os membros do grupo.

$\mathrm{Na}$ sessão seguinte, cada estudante apresenta aos colegas o que pesquisaram e aprenderam em relação ao caso, suas conclusões ou eventuais dúvidas. Ao final, as hipoteses são reexaminadas e novas questões de aprendizagem podem aparecer e requerer nova pesquisa por informação adicional. Cada tutorial é finalizado com uma avaliação do grupo e da performance individual. Nos dois grupos observados, embora os alunos tenham que discutir em cada caso os aspectos biológicos, psicológicos e populacionais, observou-se que os alunos dão maior ênfase aos aspectos biológicos ou bioquimicos do que aos outros aspectos, pelo menos nas fases iniciais do curso.

Algumas vantagens são apontadas pelos professores em relação a esta metodologia de ensino, que eles não verificam nas aulas tradicionais:

A Aprendizagem Baseada em Problemas é muito mais eficiente para os alunos aprenderem sozinhos, do que ter aula (conferencia) com professores que tentam ensinar a eles e nós achamos que quando os alunos têm controle de sua própria educação, eles procuram mais artigos e são muito mais alegres, $e$ fazem isso totalmente por conta própria. Então eu penso que é uma medida muito boa, é uma medida indireta do quão bem vocé pode treinar alguém para ser auto-aprendiz.

Os alunos têm ainda, e ao mesmo tempo que os tutoriais nas Fases I e II, aulas expositivas relacionadas ao bloco e também aulas práticas em laboratório, conforme anexo 5

A prática clínica acontece desde o primeiro dia, inicialmente uma vez por semana, aumentando progressivamente durante o curso. Ao final, todos os alunos devem entregar uma monografia, versando sobre assunto escolhido por eles mesmos

A metodologia de ensino combina a Aprendizagem Baseada em Problemas com a prática precoce. Com a $\mathrm{ABP}$ os alunos têm maior motivação para estudar, 
desenvolver o raciocínio crítico, descobrir novos caminhos, e são estimulados a um trabalho cooperativo. Apesar de ser uma proposta considerada inovadora, a ABP depende da forma como o caso está estruturado e de como é explorados pelos alunos e tutores, pois eles podem não desenvolver uma visão problematizadora das questões culturais, sociais e econômicas envolvidas no processo saúde-doença.

E pela prática, que busca desenvolver habilidades clínicas e de comunicação, bem como estabelecer relações entre o que foi aprendido, que existe a possibilidade de problematizar o que acontece na realidade.

Quando inquiridos sobre a utilização da metodologia e algum possivel impacto sobre as necessidades de saúde da comunidade, os professores consideram que a prática é que vai ter o papel principal na aprendizagem.

Eu não penso só fazendo $A B P$, entretanto, eu penso que eles têm consciência, mas não penso que dá a eles a habilidade a influenciar o cuidado com as necessidades de saude. Eu penso que usar o saber e começar o trabalho nos cenários clínicos é que é o negócio, quando os alunos estão aprendendo sobre os pacientes é muito mais dificil ignorar os assuntos sociais do que se você estiver aprendendo sobre uma reação bioquímica. Nas escolas médicas tradicionais existe sempre uma hora por semana ou um pouco de medicina social, no fim de uma sexta-feira à tarde, quando todo mundo quer ir embora, $e$ não é integrado com o contexto da vida real do paciente na comunidade. Eu creio que a metodologia não é importante, ABP ou outros tipos de ensino, como eletrônico, não é importante ao meu ver, o mais importante é se podemos colocar o estudante na comunidade, falar com gente, a experiência, as condições da população e pensar e ler sobre os problemas com a experiência e aprender.

A ABP contribuiu para diminuir a passividade dos alunos, praticar o trabalho conjunto, a modificar as relações existentes entre as diferentes disciplinas e a relação de poder que uma grande carga horária confere aos departamentos. Nesse tipo de metodologia é necessário que os departamentos interajam mais freqüentemente, diluindo algumas arestas no processo:

A ABP não é mágica, é uma técnica para realizar uma meta, não vai mudar tudo. A ABP é melhor para estimular e motivar alunos para aprender, criar um ambiente em que o estudante aprende a trabalhar, colaborando com o grupo, para ensinar a eles fazerem perguntas, ensinar a eles a acharem respostas. De algum modo, a coisa mais importante sobre a ABP é que ela 
quebrou a barretra entre as áreas de conhectmentos diferentes. Em uma escola médica tradicional a bioquímica tem $X$ número de semanas, a histologia tem suas horas, a cirurgia tem suas horas e todos protegem seu tempo. A ABP atravessa todas as especialidades, ou as ciências clínicas e básicas, e nenhum departamento pode controlar o tempo.

No caso da Escola de Medicina da UNM, o emprego de diferentes estratégias na composição do currículo e a adoção da $\mathrm{ABP}$ ampliaram a possibilidade de ir ao encontro das necessidades de saúde:

Outra coisa importante é que a introdução da ABP nos ajudou a conseguir mais docentes trabalhando em conjunto, tempo para os alunos irem mais cedo na comunidade, e conversarmos mais sobre necessidades de saúde da comunidade. Colocar precocemente os alunos nas cidades menores do Estado realmente permite que eles vejam os problemas e espero que os ajude a agir no futuro, tentando beneficiar as pessoas do Estado.

Quanto às necessidade de formar médicos especialistas ou generalistas, os professores consideram que no Novo México ainda há uma grande necessidade de médicos de cuidados primários, mas também fazem referência à necessidade de alguns especialistas que fazem falta ao Estado:

Nós precisamos de médicos de cuidados primários, porque NM tem um grande problema com o acesso geográfico e a distribuição de posições de trabalho e acesso a cuidados de saúde. Muitas pessoas pobres têm que decidir entre comida e medicina. Nós fazemos melhor do que a média nacional em termos de colocar médicos de cuidados primários nas zonas rurais e em áreas não servidas. Os obstáculos para alcançar este objetivo são muito mais políticos, o HCFA, a Administração de Financiamento em Saúde decide as regras (HCFA, Health Care Financing Administration), que financia residencias e programas e tem tornado muito dificil treinar médicos de cuidados primários Nós também precisamos de cirurgióes e neurocirurgiões. Os hospitals ganham muito dinheiro tendo cada vez mais residentes de especialidade, e então a sociedade está sendo inundada com especialistas desnecessários. Nós estamos perto de ter o número certo de doutores de cuidados primários, ocorre que nos Estados Lnidos eles não são bem distribuidos...

\subsubsection{Desenvolvimento dos Casos Clínicos}

Os casos utilizados nos tutoriais são preparados pelos coordenadores dos blocos, pela temática do bloco que está sendo realizado. Há um grupo de trabalho 
transdisciplinar que tem como função manter uma comunicação regular com os outros grupos responsáveis pelos casos dos outros blocos. $\mathrm{Na}$ pratica existe uma grande variação no desenvolvimento dos casos:

Os coordenadores do bloco selecionam os casos em geral. Todos os comitês de bloco são grupos de docentes de departamentos e disciplinas diferentes.

Quando perguntado sobre os critérios de escolha de casos, observou-se que os critérios são variáveis. Quando comparados com os problemas de saúde elencados pelo Departamento de Saúde do Novo México, observou-se que alguns coordenadores selecionam os casos de seus blocos com base epidemiológica, buscando retratar os problemas mais prevalentes no NM, como alcoolismo, diabetes, obesidade, cardiopatia, acidentes e depressão. Outros coordenadores escolhem o assunto e escrevem o caso de acordo com o conteúdo que desejam ensinar, por exemplo se desejam ensinar a respeito de vírus ou bactéria (UNIVERSITY OF NEW MEXICO 1998e).

Os critérios são variáveis. Em geral, os coordenadores dos blocos estão pedagogicamente conscientes e escolhem tópicos que são casos caracteristicos que os alunos podem generalizar ou particularizar. Alguns professores menos conscientes escolhem o mais comum ou aquilo em que eles estão interessados, ou o que pensam que os alunos deviam conhecer. Eu penso que não existe nenhum critério fixado, não existe um sistema para isto.

Um dos pontos importantes em relação aos casos foi que, para conseguir realizar a reforma, foram feitos alguns acordos entre os docentes, e um deles era a liberdade que cada departamento teria na elaboração e seleção do que seria ensinado, tanto em relação aos casos como nas aulas e laboratório:

Quando nós mudamos o currículo, os docentes não queriam perder o controle que era só de alguns. Então, eles fizeram suas regras de forma que cada grupo escolheria seu próprio material. (como resultado, nós podiamos fazer a mudança política. O conteúdo do currículo não era coerente, aderente, e ainda hoje sofremos com isto. Nós fomos forçados a isto em troca de ter um novo currículo. É muito dificil de fazer isso, nós estávamos muito ocupados lutando batalhas políticas. Naquele momento a preocupação era a mudança, achamos que nós nos preocupariamos com os casos mais tarde. 
Os casos são vistos como ferramentas para a aprendizagem do aluno e como veículos para os docentes manterem uma certa proximidade:

Bem, eu penso que eles los casos] são só outra ferramenta em todos os tipos de experiências que eles /os estudantes] estão tendo durante seus quatro anos aqui para aprenderem a miriade de habilidades e conhecimento diferentes, julgamento e habilidade de raciocínio que os ajuda a serem médicos.

O que se pôde observar é que existem casos clínicos que são descritos de maneira mais interessante ou desafiadora para os alunos, em que se percebe que houve uma preocupação com sua elaboração final. Outros casos são desenvolvidos de maneira mais tradicional e são mais diretivos. Quando perguntados se existe maior ênfase nos conteúdos biológicos, os professores assim se expressaram:

Na Fase I, o caso é escrito com base no biológico e você adiciona a população. Quando os alunos chegam na Fase II, eles descobrem isto como atendimento de pacientes dificeis ou de paciente que não tem seguro, ou com o que é a vida do paciente na parte mais violenta da cidade, eu penso que isto $e ́$ quando eles realmente aprendem e ficam conscientes dos fatores psicosociais, é quando eles realmente conversam com o paciente.

Não ficou suficientemente claro o nível de envolvimento dos docentes nos casos, uma vez que a responsabilidade de desenvolver o caso fica a cargo do coordenador de bloco, que pode ou não chamar outros docentes para trabalharem em conjunto. Os coordenadores de bloco são escolhidos por seus pares e podem ser um médico ou um cientista básico.

O acordo para a realização da reforma da Escola de Medicina também incluiu uma redução do número de departamentos das ciências básicas, agrupando-se disciplinas afins. O coordenador de bloco portanto é representante de um conjunto de disciplinas. 


\subsubsection{Desenvolvimento Educacional do Professor (TED)}

Esse setor tem por objetivos facilitar e promover o desenvolvimento de habilidades de liderança, ensino e pesquisa em inovação em educação [DIVISION OFF EDUCACIONAL DEVELOPMENT AND RESEARCH 1998-1999 REPORT.].

Com o estabelecimento de um Currículo de Cuidados Primários em Saúde (CCPS) na Escola de Medicina da UNM em 1979, surgiu a necessidade de desenvolver docentes capazes de trabalhar como facilitadores da aprendizagem. Para isso, estabeleceu-se uma oficina experiencial e interativa de treinamento em habilidades educacionais, na Aprendizagem Baseada em Problemas e no ensino centrado no estudante. O sucesso do CCPS conduziu a Organização Mundial de Saúde a designar a Escola de Medicina da UNM como um centro colaborador para a disseminação da Aprendizagem Baseada em Problemas centrada na comunidade. As inovações no desenvolvimento dos docentes continuaram com a implementação do currículo integrado em 1992, no sentido de combinar e estender as melhores caracteristicas do CCPS e do curriculo tradicional em um único currículo.

\section{Treinamento de tutores}

Os tutores são treinados em oficinas de trabalho oferecidas várias vezes ao ano pelo Setor de Desenvolvimento Educacional do Professor (TED). A oficina dá ênfase no processo tutorial e no desenvolvimento de habilidades de coordenação de tutoriais. Os participantes têm a oportunidade de participar como tutores de um grupo voluntário de alunos e discutir essa experiència com tutores experientes. Há uma situação de imersão na oficina por uma semana que discute os tópicos relacionados a seguir: aprendizagem centrada no estudante, o processo tutorial, o papel do tutor como facilitador de um processo de ensino-aprendizagem, características eficientes/efetivas de grupo tutorial e do tutor, habilidades práticas e estratégias de dinâmica de grupo tutorial, e avaliação e retroalimentação de estudantes e tutores (UNIVERSITY OF NEW MEXICO 1999b).

No primeiro dia os docentes recebem um caso que eles mesmos discutem em grupo e experienciam sua participação num grupo e na construção do conhecimento. 
Nesse dia, todos são observados por tutores experientes, que vão retroalimentando com avaliações e informações sobre o processo tutorial.

No segundo dia os docentes atuam como tutores facilitadores de um grupo de alunos voluntários que discutem um caso. Todos os participantes têm a oportunidade de participar como tutores e ao final da participação recebem também uma avaliação de sua atuação. No terceiro dia são realizadas discussões teóricas sobre os tópicos descritos acima. No quarto dia os docentes voltam ao papel de tutores do mesmo grupo de alunos e podem observar em que medida a metodologia influi na aprendizagem e na construção do conhecimento do estudante. O quinto dia é reservado para o desenvolvimento de casos e objetiva treinar participantes no processo de planejamento e desenvolvimento de casos. Os participantes são divididos em pequenos grupos e realizam a tarefa de escrever um caso para ser usado num curriculo de Aprendizagem Baseada em Problemas sob a supervisão de um facilitador experiente. Para finalizar os trabalhos, há um processo de avaliação da oficina.

Existe uma preocupação com o treinamento dos docentes e estes estão sendo preparados para discutir fatores que vão além do biológico:

Bem, treinar tutores é um grande problema, e eu penso que nós treinamos tutores em NM melhor que qualquer outro lugar. Nós temos um dos melhores treinamentos de tutores, eu tenho visto tutores treinados em alguns outros lugares que não tão bons.

\section{Aulas e apresentações formais}

Outra atividade de treinamento oferecida pelo setor é o desenvolvimento de habilidades de preparação e planejamento de aulas expositivas e apresentações formais. É realizado em um só dia. No periodo da manhã há uma demonstração de aula com discussão e utilização de estratégias e manejo de técnicas de ensino para captar a atenção dos ouvintes. No período da tarde, cada participante prepara e apresenta uma aula que é filmada e comentada pelos participantes. 


\section{Opções em educação em ciências da saúde}

Essa é uma oficina de trabalho que tem a duração de uma semana e acontece anualmente. Tem como finalidade a discussão dos seguintes tópicos: (1) métodos de aprendizagem em pequenos grupos, (2) tutoriais de Aprendizagem Baseada em Problemas em curriculo integrado, (3) avaliação de estudantes e de tutoriais, (4) desenvolvimento de casos para currículo baseado em problemas, (5) o processo de mudança. A população-alvo são docentes de áreas da saúde da própria universidade ou de outras universidades americanas e estrangeiras.

\section{Educação médica}

O TED desenvolve ainda um programa de educação médica, (Medical Education Scholars - MES), projetado para desenvolver lideres e educadores médicos na Escola de Medicina. A finalidade do programa é assegurar um continuum de liderança educacional para a instituição. Tem como clientela os docentes iniciantes que vêem sua instrução em educação médica como uma parte significativa de seu desenvolvimento profissional.

Os participantes do programa de MES se reúnem em grupo uma vez por semana (três horas) num curso que tem duração de dez meses. Há também sessões individuais com o diretor do TED. Com cada participante é realizada a observação e discussão de atividades de ensino em sala de aula, como uma espécie de supervisão clínica. São discutidos e aprofundados temas como ensino-aprendizagem, avaliação, desenvolvimento de currículo, pesquisa educacional em programas acadêmicos, liderança acadêmica, gerência financeira e qualidade na educação médica, entre outros.

Cada participante do MES identifica e desenvolve uma área de interesse, de acordo com os objetivos individuais de sua carreira, e então recebe suporte departamental e institucional para publicar e/ou apresentar seus trabalhos em reuniões e conferências profissionais. 


\section{Treinamento de professores iniciantes e residentes}

O TED também tem o papel de integrar inicialmente os novos membros contratados pela faculdade e os novos residentes. Para os primeiros é realizado um seminário interativo sobre o sistema educacional utilizado na escola, os objetivos educativos, a avaliação e retroalimentação e os recursos disponiveis na universidade.

Para os residentes é realizada uma oficina com o objetivo de fornecer uma breve noção sobre aprendizagem, estratégias para criar um ambiente positivo de aprendizagem, diagnóstico das necessidades de aprendizagem, avaliação e identificação de recursos educacionais que são utilizados durante a residência.

\section{Orientação ao aluno ingressante}

Há uma orientação inicial de dois dias, conduzida pelo TED, para os ingressantes da medicina. O primeiro dia é projetado para preparar os estudantes a participarem eficazmente do processo tutorial. A agenda inclui: a introdução do currículo centrado no estudante, a Aprendizagem Baseada em Problemas, a introdução aos tutoriais e o trabalho em pequenos grupos. Os estudantes participam em tutoriais simulados em que têm a oportunidade de experimentar o processo em um ambiente seguro antes que seu primeiro bloco tutorial comece oficialmente.

Convém ressaltar que os ingressantes da Escola de Medicina já vem com um curso de bacharelado completo, normalmente nas áreas das ciências biológicas, mas também em ciências humanas.

\section{Reunião de tutores}

Os tutores, através do TED, são convidados a comparecer a um fórum mensal (Tutor Dialogues) para explorar e discutir questões, e estratégias do processo tutorial. As reuniões são realizadas durante a hora do almoço, os tópicos variam a cada mês. Eis alguns exemplos de tópicos discutidos nestas reuniões: problemas comuns nos tutoriais; estratégias de ajuste nos tutoriais, estratégias e avaliação das habilidades nos tutoriais; co-tutoria etc. As reuniões são anunciadas através de cartazes e pelo correio 
eletrônico de cada docente da Escola de Medicina e o comparecimento é voluntário (anexo 8).

\subsection{Avaliação}

O processo de avaliação e seus resultados em geral, na maioria das instituições, é difícil de ser acessado através de entrevistas e observação. A Escola de Medicina do Novo México não foge à regra. Somente nos tutoriais houve a oportunidade de observar as avaliações diárias e a avaliação final de cada bloco investigado. Vale ressaltar que a Escola de Medicina tem um complexo sistema de avaliação, que será descrito a partir da análise documental (THE UNIVERSITY OF NEW MEXICO 1998d; THE UNIVERSITY OF NEW MEXICO 1999a; THE UNIVERSITY OF NEW MEXICO 2000; THE UNIVERSITY OF NEW MEXICO, de conversas informais com $\mathrm{C}(1)$ e da extensa produção de artigos e publicações sobre avaliação na Escola de Medicina da UNM (MOORE-WEST, HARRIGTON, MENNIN, KAUFMAN, SKIPPER 1989; FRIEDMAN, BLIEK, GREER, MENNIN, NORMAN, SHEPS, SWANSON, WOODWARD 1990; MENNIN, FRIEDMAN, SKIPPER, KALISHMAN, SNYDER 1993; MENNIN, KALISHMAN, FRIEDMAN, PATHAK, SNYDER 1996).

Desde o início do CCPS em 1979 a avaliação sempre foi uma preocupação dos professores, por isso se organizou um setor sobre pesquisa e avaliação. A seguir, alguns aspectos da avaliação do estudante e da avaliação do programa são apresentados.

\section{Avaliação do estudante}

A avaliação é parte integral do currículo da Escola de Medicina do Novo México. Os líderes do currículo acreditam que avaliação e aprendizagem são inseparáveis e buscam desenvolver e usar a avaliação como parte da educação dos alunos. Para estes, a avaliação é um momento da aprendizagem. Entretanto a avaliação na Escola de Medicina do NM ainda utiliza simultaneamente recursos tradicionais e inovadores $\mathrm{C}(1)$. 
Utiliza recursos tradicionais, porque os alunos passam por testes durante as Fase I e II, testes que envolvem perguntas de múltipla escolha, e também passam por exames nacionais, os quais têm questões baseadas principalmente na memorização de conhecimentos. Por sua vez, cada bloco da Fase I exige que o aluno passe por uma prova semestral e um exame final, ambos baseados principalmente nos conteúdos das aulas e de laboratório. Os alunos recebem um grau em cada bloco com base nos resultados obtidos. Os graus variam de Excelente $(A)$ a Insatisfatórios (F). Os graus são calculados em um sistema que varia de 0 a 4.0, 4.0 é o equivalente a $\mathrm{A}, 3.0$ equivale a $B, 2.0$ equivale a $C$ e 1.0 equivale a um $D$ e 0 compreende a letra $F$, que significa reprovação. Os alunos têm que obter no mínimo o grau Satisfatório $(C=2.0)$ em todos os blocos para poder progredir.

Os tutoriais são avaliados de maneira semelhante em relação aos graus descritos anteriormente, mas os critérios são derivados de uma análise subjetiva pelo tutor. A análise inclui quatro áreas, conhecimento, raciocinio, comunicação e avaliação. Os critérios específicos para guiar os tutores estão estabelecidos no curriculo. O grau do tutorial é, portanto, formativo, mas também pode reprovar aluno.

O sistema de avaliação do aluno é composto por três diferentes momentos ao longo dos quatro anos da escola: (1) Avaliação tutorial, (2) Avaliação de bloco e (3) Avaliação de desempenho (SPA).

\section{(1) Avaliação tutorial}

Ao final de cada tutorial, isto é, duas vezes por semana, os alunos realizam nos 30 minutos finais, uma avaliação que envolve quatro habilidades: (1) integração critica de conhecimento, (2) raciocínio, (3) comunicação, (4) auto-avaliação e avaliação dos pares. Nesse momento os estudantes expõem como se sairam durante aquela sessão, se conseguiram ou não estudar e se preparar para a sessão, como e se puderam ou não ajudar o grupo na busca de soluções para os problemas levantados e também avaliam seus colegas e o tutor. Os estudantes apontam suas deficiências e qualidades, se conseguiram progredir nos temas ou se tiveram problemas. De um modo geral, a avaliaçào é um momento muito positivo no grupo. Os estudantes sempre utilizam palavras positivas de incentivo para os colegas, quando percebem, 
por exemplo, os esforços de superação dos problemas, seja com relação aos conteúdos, seja com relação ao comportamento. Uma situação observada no transcorrer de um tutorial pode ilustrar isso melhor.

No primeiro grupo observado, havia uma aluna extremamente tímida, para a qual era um grande esforço falar para o grupo, ir para o quadro e apresentar aos colegas o material que tinha pesquisado (que invariavelmente estava muito bem preparado e que ela explicava muito bem quando superava a timidez). Quando lhe dirigiam a palavra, ela ficava sempre muito vermelha e envergonhada. Em uma das sessões do bloco musculoesquelético, os alunos examinavam um RX de um trabalhador que havia tido um acidente e sofria uma forte dor no ombro. Para entender melhor o problema, o tutor tomou como exemplo o ombro dessa aluna e mostrou a localização exata do que eles viam no RX de ombro, e ela se sentiu muito mal por ter sido tocada. Como nas avaliações os membros do grupo a vinham incentivando muito para que ela pudesse superar a timidez e se expressar mais no grupo, ela conseguiu expor seu mal-estar para o grupo, que trabalhou este conteúdo em diferentes níveis.

Existe um comitê de direção tutorial, que teve início em 1996, para monitorar os tutoriais no currículo. O comitê criou mecanismos para assegurar que as avaliações tutoriais venham ao encontro das necessidades do Comitê de Avaliação e Promoção do Estudante (CSPE I) e dos próprios estudantes. O grupo também desenvolveu critérios para as avaliações escritas dos estudantes, utilizando suas narrativas e a avaliação do seu comportamento nos tutoriais. Um manual de referência intitulado Guia para a Avaliação nos Tutoriats foi impresso e distribuido a todos os tutores e estudantes, e contém todos os critérios para avaliar os tutoriais (anexo 9).

\section{(2) Avaliação de bloco}

É uma avaliação tradicional com teste de múltipla escolha que remonta ao conteúdo das aulas e de laboratório.

No fim de todo semestre os tutoriais e os graus do bloco são calculados em um grau global médio. A combinação dos tutoriais e dos graus de bloco é o que determina se um aluno pode progredir para o próximo semestre ou para a fase próxima. 


\section{(3) Avaliação de desempenho (SPA)}

O desempenho do estudante é analisado em três diferentes momentos durante os quatro anos da escola através da SPA - Student Progress Assessment, que foi instituída a partir de 1993 e busca avaliar cinco competências: 1) habilidades clínicas, 2) comunicação, 3) integração crítica do conhecimento, 4) atitude profissional, valores e ética e 5) auto-avaliação (UNIVERSITY OF NEW MEXICO: SCHOOL OF MEDICINE. STUDENT PROGRESS ASSESSMENT 1998d).

A SPA-1 acontece no final do primeiro ano (antes da experiência de PIE) na Fase I, é formativa e pode reprovar o aluno. A SPA-2 acontece no princípio da Fase II e e formativa e somativa. É somativa para os alunos que estavam em recuperação para poder continuar a Fase seguinte. A SPA-3 acontece no princípio do $4^{\circ}$ ano de estudo, durante a Fase III, é uma avaliação sequencial em que o estudante tem a oportunidade de demonstrar capacidades e habilidades desenvolvidas em cada uma das cinco competências. É também avaliação somativa e requerida para a graduação. Os alunos podem ter passado nos blocos e na Fase II, mas devem também estar bem na SPA.

A SPA é o único exame que avalia totalmente a capacidade e o desenvolvimento de habilidades dos alunos. Cobre todo conteúdo e exige que o aluno integre conhecimento, capacidades e habilidades.

Além das avaliações de bloco, e dos tutoriais e de desempenho, os alunos têm de passar pelo Exame de Licença Médica dos Estados Unidos (USMLE), composto de duas etapas. A primeira ocorre no início da Fase III ( $3^{\circ}$ ano) e a segunda etapa na mesma fase, mas no $4^{\circ}$ ano. $O$ aluno que não passar pela primeira fase deve realizar o exame novamente antes de continuar com o curso de medicina. É com este exame, que o setor de avaliação compara o desempenho dos alunos da Escolas de Medicina do NM com as outras escolas americanas.

Atualmente os planejadores de currículo estão revisando a abordagem da avaliação para eliminar os exames dos blocos e substitui-los com mais avaliações de desempenho na Fase I. As avaliações da Fase II estão mudando cada vez mais em direção às avaliações dos objetivos clínicos em cada estágio do internato. O que se pode perceber é que há uma grande atenção dada à avaliação do aluno. 


\section{AVALIAÇÃO do PROGRAMA}

A introdução de curriculos inovadores na educação de profissionais de saúde tem criado uma necessidade para entender e avaliar os resultados e a influência dessas modificações curriculares a curto e a longo prazo (MENNIN, WOODWARD E FRIEDMAN, 1992).

A avaliação do programa é um processo pelo qual as metas e objetivos educacionais do currículo são avaliados. Inclui o desempenho do aluno nas avaliações, perspectivas dos alunos e docentes no currículo, mudanças curriculares, desempenho dos graduados durante a pós-graduação (residência), e seguimento dos graduados na prática profissional.

O Setor de Avaliação do Programa, Educação e Pesquisa (PEAR) ligado ao TED é encarregado dessa responsabilidade na EM-UNM.

A finalidade do PEAR é a avaliação e pesquisa em educação e saúde. É composto por um grupo de educadores, avaliadores, e biostatísticos situados na Escola de Medicina da UNM. O PEAR é reconhecido nacional e internacionalmente pelas suas pesquisas em avaliação, iniciativas educacionais nas profissões de saúde, projetos interdisciplinares e de comunidade. O PEAR teve inicio em 1979 e é um grupo de avaliação que se concentra na educação médica e na educação das profíssões de saúde, e tem se responsabilizado também pela avaliação do processo e do impacto de experiências educacionais nos alunos, nos docentes e na instituição. 
Capítulo 5

Discussão 


\section{Capítulo 5 - Discussão}

O estudo da trajetória da Escola de Medicina da UNM, as barreiras, as estratégias, os sucessos e as falhas podem enriquecer a discussão e a reflexão sobre propostas de mudança e trazer novas contribuições para a discussão da educação médica na atualidade.

Do estudo emergiram alguns aspectos importantes para reflexão e discussão: (1) o processo de mudança: o momento social, político e financeiro e a correlação de forças internas e externas à mudança; (2) a reforma curricular: a Aprendizagem Baseada em Problemas, a prática clínica precoce e a educação voltada para a comunidade; (3) a seleção e desenvolvimento de casos clínicos e as necessidades de saúde da comunidade; (4) a formação, o desenvolvimento e a participação dos docentes; (5) e a avaliação como parte integral do processo de mudança e da aprendizagem.

\section{(1) o processo de mudança: o momento social, político-financeiro; os objetivos da escola de medicina e a correlação de forças internas e externas à mudança}

A Escola de Medicina do Novo México conseguiu aproveitar duas forças convergentes, uma interna e outra externa para articular o processo de mudança: a insatisfação de alguns professores com o processo de ensino desenvolvido na escola e a necessidade de médicos em âmbito nacional e estadual para atender a população. A integração dessas duas forças garantiu a introdução do Currículo de Cuidados Primários em Saúde (CCPS) e posteriormente a introdução do currículo atual.

No estudo de caso ficou claro que a insatisfação com a educação médica e o descontentamento com a pedagogia tradicional dentro do currículo médico, e mais especificamente em como a Medicina Familiar e Comunitária estava sendo ensinada, foram as motivações significantes para iniciar a mudança para o Currículo de Cuidados Primários em Saúde (CCPS) na Escola de Medicina da Universidade do Novo México.

O descontentamento com a educação médica e com o currículo também foi a mola propulsora para a Universidade McMaster, na verdade a primeira Escola de 
Medicina a implantar uma nova abordagem educacional (BARROWS 1996) Outro autor da mesma escola corrobora a história da mudança curricular, afirmando que foi a insatisfação dos alunos e também dos professores com o formato tradicional de ensino médico que impulsionou a mudança (SPAULDING 1969).

AGUIAR (2000), estudando as mudanças curriculares na Escola de Medicina de Harvard (HMS), aponta os motivos que levaram uma escola tão reconhecida e famosa a realizar uma mudança curricular. Um deles foram os questionamentos sobre os rumos da prática e da educação médica americanas, fomentados pelos movimentos sociais e sistematizados pela Association of American Medical Colleges (AAMC), que enfatizava a importância: da preparação dos estudantes em promoção de saúde e prevenção de doenças em indivíduos e comunidade; da educação permanente; do estímulo do raciocínio critico na identificação, formulação e resolução de problemas e na avaliação das informações; da aquisição de atitudes e habilidades em vez de somente o conhecimento; do processo de ensino-aprendizagem centrado no estudante; da diminuição da ênfase na memória; do foco da aprendizagem centrado nas necessidades dos pacientes e suas familias; do docente exercer papel de mentor, e não de transmissor do conhecimento. Outro foi o diagnóstico da situação elaborado no final da década de 1970 pela comunidade acadêmica da HMS, que mostrava um quadro bastante semelhante ao que atualmente presenciamos em muitas escolas brasileiras: uma massa de estudantes "anônimos" sendo "assoberbada" por informações "fragmentadas" transmitidas em aulas expositivas de qualidade "variável", num processo que valoriza mais a memorização do que o raciocínio crítico (AGUIAR 2000).

Ainda na década de 1970, outras escolas de medicina também modificaram seus currículos tradicionais para outro de aprendizagem ativa, como o College of Human Medicine, na Michigan State University, que implementou um currículo baseado em problemas nos anos pré-clínicos, a Escola de Maastricht (Holanda) e a de Newcastle (Austrália), porém não está claro na literatura porque motivos elas assim agiram. Mas é interessante observar em lugares tão diferentes e distantes o mesmo descontentamento ante o ensino e a resposta inadequada da formação médica às necessidade sociais levaram as pessoas a buscar novas alternativas para a educação. 
Possivelmente a conjuntura política e a organização da prática médica em cada um desses países também tiveram sua contribuição.

A Escola de Medicina de Sherbooke em Quebec (Canadá), igualmente realizou uma completa reestruturação curricular em 1987, após diagnosticar que seu programa de ensino não era capaz de diplomar médicos com formação humanística, que pudessem melhorar a saúde da população e responder às necessidades da sociedade (DES MARCHAIS, BUREAU, DUMAIS, PIGEON 1992).

Aqui no Brasil, na Universidade de Londrina, a mudança foi realizada por uma conjunção de fatores que mobilizaram as discussões sobre as questões acadêmicas e curriculares: a insatisfação dos professores e alunos com os métodos de ensinoaprendizagem tradicionais; as insuficiências do modelo acadêmico; as dificuldades com os serviços de saúde e o descontentamento dos egressos com a formação recebida durante a graduação. Além disso, a participação no projeto UNI, o processo de avaliação desencadeado pela CINAEM, o apoio da OPAS com a formação de recursos humanos de saúde e as intensas discussões iniciadas em 1991 também impulsionaram as mudanças. Londrina também sediou um Congresso de Educação Médica e o I Seminário dos Projetos UNI além de estar associado à Network of Community-Oriented Educational Instituitions for Health Sciences, que são importantes fóruns de discussões sobre reformas curriculares. (ITO 1994).

O momento político que impulsionou a mudança nos EUA nasceu da percepção nacional e dos governos de Estado sobre a falta de médicos em relação à população quando da realização dos exames nacionais e estaduais (National Board of Medical Examiners, The State Boards of Medical Examinations) - exames que permitem a prática da medicina. No Novo México, a legislação estadual propiciou a abertura da Escola de Medicina na esperança de que ela proveria a formação de médicos nascidos no próprio Estado e melhoraria o acesso aos cuidados de saúde entre as populações rurais novo-mexicanas. Entre o tempo que a Escola Médica começou em 1964 e o tempo que Kaufman chegou ao Novo México estava havendo uma diminuição constante da cobertura em cuidados primários e na formação de médicos para atender às necessidades do estado. Portanto, existia uma crise em meados de 1970 que serviu como foco para mudar os métodos de educação. Como relatado nas entrevistas, a idéia inicial era colocar os alunos na comunidade já durante 
seu primeiro ano de estudo para realçar a aprendizagem com base na comunidade. Só mais tarde eles descobriram a Aprendizagem Baseada em Problemas e uniram as duas idéias inovadoras na primeira reforma curricular (CCPS). As declarações de Kaufman sobre seu trabalho em comunidades rurais e como isso o levou a entender que a aprendizagem real vinha dessas experiências, induziram os idealizadores do projeto a pensarem desde o início em um curriculo orientado para a comunidade, o que era diferente por exemplo, dos currículos das outras escolas de medicina que ja tinham implantado uma nova abordagem educacional. No caso do Novo México, a experiència mais poderosa começou na comunidade. As entrevistas com os professores que participaram do CCPS mostraram que eles desenvolveram o novo currículo como uma alternativa experimental ao currículo tradicional (KAUFMAN, 1985).

Pelo menos mais dois fatores devem ter influenciado a equipe da Escola de Medicina do Novo México a iniciar o CCPS, que porém não foram assinalados nas entrevistas nem análise documental. Um deles foi a proposta da Medicina Comunitária, que segundo DONNANGELO e PEREIRA (1976) surgiu como uma estratégia de prestação de serviços à população onde a estrutura não era suficiente para resolver a problemática de extensão e sustentação de serviços médicos e cujo objeto eram as categorias sociais excluidas do processo de medicalização. Outro fator foi a Declaração de Alma-Ata em 1978, que tinha como proposta os CPS, o trabalho em comunidade com núcleo na família e a participação comunitária em que os individuos e famílias deveriam assumir a responsabilidade pela saúde e o bem-estar próprios e da comunidade. E no Novo México foi exatamente o Departamento de Medicina Familiar e Comunitária que iniciou o novo currículo, com o ideário de CPS.

Do ponto de vista externo havia a necessidade de conseguir recursos financeiros para iniciar o CCPS, que vieram através do apoio da Fundação Kellogg. Quando aconteceu a fusão dos dois currículos, em 1993, a ajuda veio com a chegada de uma alta soma de recursos financeiros proveniente da Robert Wood Johnson Foundation. Esta fundação ofereceu recursos para apoiar projetos nas escolas de medicina americanas que tinham uma história de trabalhos comunitários e um ideário de humanização da medicina. A Escola de Medicina do Novo México foi uma das 
escolhidas o que fez com que os docentes da instituição se congregassem no esforço de construir uma nova proposta curricular.

Na UNM, desde a implantação do CCPS em 1979, até o presente momento, o objetivo da Escola de Medicina tem sido formar médicos generalistas, ou médicos de cuidados primários em saúde. Uma pesquisa realizada em 1996 com os alunos formados no CCPS, mostrou que eles escolhiam, em maior proporção, trabalhar em carreiras de cuidados primários em áreas rurais e também em maior proporção, escolhiam ser médicos de família (MENNIN, KALISHMAN, FRIEDMAN, PATHAK, SNYDER 1996). Nesta e em outras avaliações, a Escola de Medicina tem sido bem sucedida em atender aos objetivos da escola e daquela sociedade, pois aproximadamente $50 \%$ dos alunos da UNM escolhem uma das carreiras que compõe o Cuidado Primário de Saúde nos EUA, que compreende a formação em clínica geral/medicina interna, em medicina de família, em pediatria, e em ginecologia/obstetrícia. Tanto a Medicina Comunitária que nasceu naquele pais para dar uma resposta aos setores populares excluidos dos beneficios dos cuidados de saúde, quanto o fórum de Alma Ata, que, sob o mesmo motivo mas sob uma capa mais ampla, propôs uma reforma visando a racionalização do setor saúde através dos CPS influenciaram bastante a reforma da educação médica na Escola de Medicina do Novo México. Porém o contexto socioeconômico e político foi se modificando ao longo dos anos, em particular com relação ao setor saúde, que cada vez tem menos resposta para os excluídos

Conforme relatado no Capítulo 3, considerando-se a atual conjuntura do Estado do Novo México em que os serviços de saúde são eminentemente privados, por que o Estado continua a necessitar de médicos de cuidados primários em saúde? O sistema continua organizado para que a atenção primária em saúde seja a porta de entrada e ao que parece isso tem funcionado ao longo de todos esses anos. Para os setores excluídos, existem os serviços públicos de atenção e as clínicas comunitárias ligadas ao Departamento de Medicina Familiar e Comunitária que como discutido no capítulo 3, não conseguem dar cobertura para um grande contingente da população. Entendendo esta lógica, parece claro que a Escola de Medicina do Novo México está cumprindo seu papel de formar médicos para as necessidades daquela sociedade. $E$ isso está de acordo com a concepção de SCHREIBER (1980), de que as 
reformulações educativas não têm sucesso se não corresponderem aos rearranjos da prática médica.

Conjugando as forças internas e externas, os idealizadores utilizaram como estratégia de mudança um projeto-piloto que se mostrou até certo ponto eficiente naquela realidade. A mesma estratégia foi adotada por outras escolas de medicina nos EUA e também em outros paises (KAUFMAN 1985; KANTROWITZ, KAUFMAN, MENNIN, FULOP e GUILBERT, 1987)

O projeto-piloto descrito no estudo de caso permitiu aos participantes um longo periodo de tempo, em que foi possível buscar e aprender melhores estratégias na experimentação do currículo. Ou seja, houve tempo para desenvolverem habilidades e testarem novas possibilidades dentro do CCPS, que foram posteriormente utilizadas no currículo atual.

Existem outras experiências curriculares nas escolas médicas americanas. Por exemplo, Harvard teve um currículo paralelo nos mesmos moldes que a Escola do Novo México por um período de três anos, e logo fundiu os curriculos (BARROWS 1996; AGUIAR 2000). Rush Medical College manteve dois currículos paralelos por mais de quinze anos e só recentemente promoveu a fusão, perdendo no processo alguns elementos da proposta inovadora. Caso similar ocorreu com a fusão curricular da Escola de Medicina do Novo México. O CCPS funcionou com um pequeno grupo que se ampliou no decorrer do tempo, ao mesmo tempo que foram aumentando também as críticas e restrições provenientes dos que não estavam envolvidos no programa. Quando se iniciou a reforma curricular, ainda havia muitos professores que não estavam preparados para a mudança e até eram contra o modelo inovador. Foi necessário um longo periodo de negociações, a perdurar até hoje, em que se perderam aspectos significativos do CCPS, mas este ainda assim pode ser considerado como bastante inovador ante aos currículos tradicionais (KAUFMAN 1985; KANTROWITZ, KAUFMAN, MENNIN, FULOP, GUILBERT 1987.

Como relatado anteriormente, algumas tentativas de experimentação curricular ocorreram aqui no Brasil entre 1965-1975, periodo em que houve a Reforma Universitária brasileira. A Universidade de São Paulo (USP), na Universidade de Brasília (UnB) e na Universidade Federal de Minas Gerais (UFMG), realizaram uma reforma curricular visando preparar médicos para as necessidades de saúde no cenário 
comunitário. Os novos currículos causaram impacto no sistema regional de saúde, percebido tanto na UnB, como na UFMG o que contribuiu para o aumento da cobertura do sistema nas duas localidades e da provisão de serviços de atenção médica, em particular pela influência do programa de internato rural. Como resultado do impacto educativo relacionado a esta experiência na $U n B$, não se observou nenhuma grande mudança nas escolhas de carreira, apenas uma parcela restrita dos formandos havia decidido praticar medicina geral em pequenas localidades e em saúde pública. A preferência dos estudantes para o atendimento de primeira linha, após passarem pelo curriculo experimental, tendia a aumentar do inicio para o fim do curso. Na USP, o curso experimental contribuiu para o movimento de renovação curricular nos anos setenta e a UFMG foi e ainda é um forte centro de disseminação de inovação nos âmbitos regional e nacional, porém não existem informações e dados quantitativos para se concluir se houve modificações em relação às opções de carreira (SOBRAL 1991). Na maior parte das vezes os projetos-piloto tem vida curta, e se não for possível generalizar a experiência para o currículo como um todo, a experiência de inovação acaba tendo resultados restritos, embora possam gerar ou influenciar outras propostas de reforma.

Também é preciso ressaltar outras experiências de medicina comunitária aqui no Brasil, porém predominantemente ligadas aos Departamentos de Medicina Preventiva, ou seja, se restringiam a um único departamento com acesso e recursos limitados que tinham a função de trabalhar junto as comunidades e, na prática tinha a atribuição de resolver qualquer coisa que fosse fora da faculdade ou do hospital. Isso historicamente eximiu os professores de clínica médica, clínica cirúrgica, tocoginecologia de qualquer compromisso com a comunidade, e além disso não se tratava de um processo de reforma curricular (CHAVES 1994).

Em contraste com a experiência brasileira, o Novo México tinha um programa inteiro num currículo voltado à aprendizagem em comunidade. A idéia de inovação desenvolvida foi a de incluir a integração das ciências básicas e clínıcas, o que era um desafio enorme, pois ameaçava o controle departamental mais do que as disciplinas especificas. Através da observação e dos depoimentos, notou-se que a existência de um curriculo paralelo experimental com a participaçào de alguns docentes é que permitiu vivenciar a integração sem ameaçar a instituição inteira e assim ultrapassar 
os limites departamentais. O currículo tradicional ainda existia, e aqueles que discordavam da inovação do CCPS tinham livre escolha de não participar do programa. Desse modo, a estratégia de currículos paralelos não ameaçou diretamente o status quo. Esses currículos paralelos duraram 15 anos. Os líderes do CCPS consideram uma falha terem mantido dois curriculos separados por um período tão longo de tempo e avaliam que deveriam ter realizado a fusão mais cedo.

Da experiência coletiva do grupo do Novo México emergiu o entendimento de como se pode dar um processo de mudança dentro de uma escola médica. A aprendizagem a partir da experiência prática não aconteceu somente em relação aos alunos, mas também a vivência prática do ensino modificou os docentes, que aprenderam a lidar com a problemática de implantação de um curriculo experimental, com uma nova proposta metodológica e com aspectos de liderança e governabilidade. Foi uma experiência que resultou numa mudança paradigmática, que foi absorvida por vários docentes.

Os resultados obtidos nesta pesquisa, comparados com as experiências relatadas na literatura demonstraram que as forças internas que intervêm no processo de mudança, diferem de acordo com a natureza da instituição, se pública ou privada. A UNM é uma universidade pública e o poder está, por tradição, nas mãos dos docentes, e não dos dirigentes. Então foi necessário um assíduo trabalho de esclarecimento dos professores ligados ao CCPS para com os outros docentes, até que houvesse um número suficiente deles envolvidos e com experiência para trabalhar em conjunto. Mesmo em instituições privadas, onde a hierarquia é respeitada com rigor e as decisões são tomadas eminentemente pelos dirigentes, como por exemplo na tradicional Escola de Medicina de Harvard, também houve a necessidade de se criar canais de comunicação e persuasão junto ao corpo docente, que revelava muitas vezes resistência, ceticismo e mesmo hostilidade com o caráter aparentemente assistemático das inovações (AGUIAR 2000). A Escola de Medicina de Sherbooke (Canadá) também teve seu curriculo modificado pela forte influência do diretor da escola.

$\mathrm{Na}$ reforma curricular, a estratégia utilizada na Escola de Medicina do Novo México foi tentar conseguir o envolvimento da maior parte dos docentes e dos dirigentes, por meio de intensivo trabalho de discussão e preparação relacionado às mudanças pretendidas. Durante o processo de desenvolvimento do novo currículo 
criaram-se comitês para que houvesse uma ligação entre o pessoal envolvido nas mudanças $e$ os que foram incluidos gradativamente. $O$ gerenciamento $e$ a implementação do currículo são responsabilidade do diretor da graduação médica e dos comitês (Comitê do Currículo e Grupo de Integração) que estão subordinados a ele. O diretor tem maior ou menor poder, de acordo com a correlação de forças entre os departamentos e com a atuação da direção da Escola de Medicina da UNM junto a estes departamentos. Como na Escola de Medicina do NM, outras escolas americanas possuem um comitê executivo responsável por todos os aspectos do currículo de uma maneira mais centralizada, o que permite a manutenção da integração curricular (ANDERSON 2000).

MENNIN e KAUFMAN (1989) consideram que a experiência vivenciada no Novo México pode contribuir com outras escolas que almejam mudar a educação médica. Com relação ao processo de implantação das inovações, eles perceberam a necessidade de envolver o maior número possivel de professores de todas as cadeiras e de pessoal, desde o início, como forma de diminuir as resistências ao novo. Os diferentes fóruns utilizados no NM tinham como objetivo realizar uma mudança que fosse de autoria dos professores, por meio de sua participação na construção coletiva do currículo. Colocaram a necessidade de avaliar freqüentemente e ajustar quando preciso a inovação. Determinaram como estratégico que o novo currículo fosse considerado um experimento, como todos os outros que ocorrem na universidade. Estabeleceram também a importância de reconhecer os méritos de todos os envolvidos e que fosse fundamental o programa manter um intercâmbio constante com outras instituições - que também estivessem modificando ou que já tivessem experiência de reformar o currículo - como forma de retroalimentação e aprendizagem, e, finalmente que a participação constante dos docentes fosse um modo de aumentar o conhecimento sobre as mudanças e da necessidade de haver um permanente compromisso com o projeto.

Algumas das conclusões a respeito da motivação para a realização $e$ implementação do processo de mudança na Escola de Medicina do Novo México estão de acordo com a avaliação deste mesmo processo nos projetos UNI realizados na América Latina. $O$ apoio financeiro externo, a capacidade de envolver amplos segmentos do corpo docente (das cadeiras básicas e clínicas, e não só de medicina 
social e saúde coletiva) na criação de alternativas na prática pedagógica, com relação às novas metodologias e novos cenários também foram determinantes na reforma curricular de Londrina e Marilia (FEUERWERKER e SENA 1999).

Em relação ao processo de mudança curricular realizadas nas escolas que participam do projeto UNI, FEUERWERKER e SENA (1999) verificaram que elas podem ocorrer em três planos de intervenção: no primeiro, as modificações são pontuais, localizadas e parciais, referentes a uma mudança na grade curricular, concentradas nos meios, nas atividades ou mesmo nas relą̧ões técnicas entre os docentes envolvidos no processo de ensino, na prestação de serviços de saúde, que são mudanças que estão acontecendo em várias escolas de medicina do país.

No segundo plano a intervenção se dá a partir dos atores e respeitando as relações de força, correspondendo ao processo de constituição de sujeitos em que se articulam o processo de formação, a prestação de serviços de saúde e a participação da população, e se estabelece novos modos de articulação entre os atores envolvidos. É um processo muito similar ao que aconteceu na Escola de Medicina do Novo México, consideradas as diferenças entre a América do Norte e a América Latina quanto ao modo de articular os serviços e a participação popular.

E no terceiro plano as mudanças na correlação de forças entre os diversos sujeitos e grupos dentro das instituições, as quais envolvem a essência do próprio processo de produção do conhecimento e da construção de novos paradigmas. São as mudanças mais amplas, que têm como alvo as relações políticas entre os sujeitos e os atores sociais institucionais (FEUERWERKER e SENA 1999).

Como podemos visualizar esses processos de mudança hoje no Brasil, nas escolas que não estão no projeto UNI? Como mudar as tradicionais escolas de medicina brasileiras, que historicamente resistem às mudanças? A aprovação das Diretrizes Curriculares Nacionais pode ser um impulso para a inovação do currículo. Com relação à organização do curso de medicina, está estabelecido nas Diretrizes que o projeto pedagógico deve ser construído coletivamente, buscando a formação integral e adequada do estudante através da articulação entre ensino, pesquisa, extensão e assistência

Os principais eixos de desenvolvimento curricular aqui no nosso meio, deverão ter por base as necessidades de saúde da população e as necessidades sociais 
com ênfase no SUS, a utilização de metodologias ativas e centradas no aluno como sujeito da aprendizagem, visando a integração e a interdisciplinaridade. Outras questões importantes são a experiência precoce em atividades práticas e o emprego de diferentes cenários de ensino-aprendizagem, a interação do aluno com usuários e profissionais de saúde, assumindo responsabilidades crescentes como agente prestador de cuidados e atenção à saúde. Ainda permanece em aberto como as escolas médicas brasileiras vão se adaptar às novas Diretrizes aprovadas recentemente.

Essas forças motrizes podem ser organizadas em direção à mudança de currículo nas escolas brasileiras. É possivel adaptar às nossas necessidades $o$ movimento de mudança realizado em outras universidades, desde que respeitadas nossas peculiaridades culturais e sociais. Marília e Londrina, que modificaram seus curriculos nessa direção servem como exemplos contemporâneos para as modificações pretendidas. As características-chave de seus programas incluem a aprendizagem orientada para a comunidade, o trabalho em pequenos grupos, a aprendizagem baseada em problema, o desenvolvimento significante das habilidades dos docentes em pedagogia e habilidades educacionais, a revisão das práticas de avaliação do aluno e a integração da comunidade, da política de saúde e da universidade em um programa coerente (LIMA e KOMATSU 1999; GARANHANI, CAMPOS, TAKAHASHI e ALMEIDA 1999).

\section{(2) a reforma curricular: a Aprendizagem Baseada em Problemas, a prática clínica precoce e a educação voltada para a comunidade}

A fusão dos currículos no Novo México exigiu que todos os docentes, técnicos e administradores mudassem. Os que eram do CCPS tiveram que aceitar uma maior estruturação e diretividade enquanto os do currículo tradicional se obrigaram a aceitar trabalhar de uma forma mais flexivel, em um currículo menos estruturado e mais participativo. Outra grande modificação foi que todos os alunos passaram a ter uma longa experiência em comunidade, que se realiza no final da Fase I, num período de quatro meses em um dos vários locais de estágio oferecidos em todo o Estado do Novo México. 
O currículo atual é o resultante de muitas mudanças ocorridas no passar do tempo. A inovação importante foi que na fusão dos currículos foi possível integrar a educação orientada para a comunidade, utilizar a Aprendizagem Baseada em Problemas e a experiência clínica precoce que não faziam parte do currículo tradicional. Por outro lado o currículo atual é misto, uma vez que emprega ainda algumas aulas expositivas ou conferências sendo portanto um pouco mais tradicional.

A abordagem pedagógica que une a Aprendizagem Baseada em Problemas, a educação com orientação para a comunidade e a experiência clínica precoce pode ser considerada como uma das inovações no currículo com implicações profundas nos modelos de escola médica no futuro e estão de acordo com a visão de John Dewey, onde não há aprendizagem em processos divorciados da experiência.

E tal consideração se contrapõe à pedagogia tradicional na qual a transmissão de informações é o ponto alto do trabalho educativo. A rápida explosão de informações, o aumento de conhecimentos novos em ciências, e a grande especialização que vivemos na atualidade têm contribuído para reforçar a fragmentação do conhecimento que vem se acentuando desde a década de 1960 . Existem mais informações do que podem ser apreendidas, comunicadas ou lidas.

Do ponto de vista educativo, mais importante do que obter informações, é estimular a capacidade do estudante de conectar idéias relevantes, em vez de fatos relevantes (DEMO 1995). É mais importante a rede de informações que ocasionam idéias emergentes do que a acumulação hierárquica de fatos (CAPRA 1996). Atualmente se sabe mais do que nunca sobre como as pessoas aprendem (BRANSFORD, BROWN, COCKING 2000). O conhecimento é estruturado em redes de conceitos relacionados, chamadas de redes semânticas (GIJSELAERS 1996).E, apesar de todo o conhecimento de psicologia cognitiva atual, o que se observa é a dificuldade de incorporá-los nas práticas pedagógicas.

$\mathrm{O}$ grande avanço da $\mathrm{ABP}$ e da educação voltada para a comunidade é a possibilidade de reduzir a fragmentação e aumentar a capacidade de construir significados que permitam a sintese do conhecimento. A síntese de CAPRA (1996) - a respeito da mudança do paradigma atual do pensamento linear para outro do pensamento não-linear - casa com as novas idéias sobre como projetar experiências educacionais interdisciplinares, transdepartamentais e integradas no lugar de 
experiências fragmentadas. A Aprendizagem Baseada em Problemas e a experiência prática em comunidade apoiam esta tendência, e isso pode vir a ser um novo paradigma na educação, desde que a ABP seja empregada no currículo como um todo, e não como uma estratégia educativa em uma disciplina.

A ABP é fundamentalmente uma abordagem construtivista de aprendizagem, em que os alunos constroem seu próprio conhecimento a partir de problemas seguidos por um processo de investigação centrado no aluno. A necessidade de conhecer é derivada de um problema que os alunos vão explorar em grupo, sob a facilitação de um tutor. Os problemas que servem como enfoque para os casos são reais, complexos e multidisciplinares, assim a aprendizagem é baseada em um contexto que o aluno estará intervindo num futuro não muito distante. Em tal metodologia a integração de ciências básicas e clínicas é mais provável que em uma aula de uma disciplina baseada na pedagogia tradicional.

Como relata MORIN 2001, a educação deve favorecer a aptidão natural da mente para colocar e resolver os problemas e correlativamente estimular o emprego da inteligência geral que exige a faculdade mais comum e ativa na infância - a curiosidade - que a instrução acaba aniquilando. $O$ autor considera trágica a extinção progressiva da curiosidade durante os anos de formação.

Há muitos caminhos para implementar a ABP. Por exemplo, não é dado a priori que a Aprendizagem Baseada em Problemas é transdisciplinar, pois existem escolas que a utiliza mais como uma estratégia de ensino em currículos baseados em disciplinas. Porém, o que é comum na ABP é que o problema vem em primeiro lugar, antes de aulas ou preparações anteriores, servindo como um incentivo à necessidade de conhecer, a partir de um contexto que é rico e realista. Os alunos determinam o que já sabem e o que precisam aprender para avançar no seu processo de compreensão do problema. Eles tomam parte na formulação sistemática de perguntas e buscam respostas, que exigem estudo e pesquisa adicional. Os alunos também tomam parte no discurso e no diálogo sobre seu conhecimento recém adquirido, dando significação ao seu saber já existente.

A ABP é muitas vezes combinada com métodos mais tradicionais de aprendizagem. O desafio aqui é verdadeiramente integrar não somente as disciplinas mas também os métodos pedagógicos, de forma que a aprendizagem do aluno seja o 
objetivo central, e não a politica de poder entre os docentes ou a mediação nas lutas departamentais.

Por exemplo, VENTURELLI (1997) considera a possibilidade que a ABP tem de combinar as prioridades de saúde com a integração conceitual de saúde e educação médica. Ele crê que a $\mathrm{ABP}$ seja flexível o suficiente para permitir e promover mudanças, porém isso também não é dado a priori. No seu nascimento, a pedagogia que dá base à Aprendizagem Baseada em Problemas foi classificada por Libâneo como uma pedagogia de tendência renovada liberal progressista. Nesta, a escola tem como função preparar os indivíduos para o desempenho de papéis sociais, de acordo com as aptidões de cada um. Para isso, eles precisam aprender a adaptar-se aos valores e normas vigentes na sociedade de classes, através do desenvolvimento da cultura individual. A ênfase no aspecto cultural esconde a realidade das diferenças de classes, pois embora difunda a idéia de igualdade de oportunidades não leva em conta a desigualdade de condições.

Ainda utilizando a classificação de Libâneo, a pedagogia que ele denomina de progressista tem três tendências: a libertadora, mais conhecida como pedagogia de Paulo Freire, a libertária e a crítico-social dos conteúdos. As duas primeiras têm em comum o antiautoritarismo, a valorização da experiência vivida como base da relação educativa e a idéia de autogestão pedagógica. Em razão disso, há um maior valor ao processo de aprendizagem grupal do que aos conteúdos de ensino. A tendência da pedagogia crítico-social dos conteúdos propõe uma síntese superadora das pedagogias tradicionais e renovada, valorizando a ação pedagógica, enquanto inserida na prática social concreta. A escola é uma mediação entre o individual e o social, exercendo ai a articulação dos conteúdos e a assimilação ativa de um aluno concreto inserido num contexto de relações sociais: dessa articulação resulta o saber criticamente reelaborado (LIBÂNEO 1986).

A título de comparação, há pontos comuns e discordantes entre a pedagogia de John Dewey e a de Paulo Freire. Ambos insistem no conhecimento da vida da comunidade local através da pesquisa do meio. A noção de cultura em Dewey é simplificada, pois não envolve a problemática social, racial e étnica, ao passo que em Paulo Freire ela adquire uma conotação antropológica, já que a ação educativa é sempre situada na cultura do aluno. O que a pedagogia de Paulo Freire aproveita do 
pensamento de John Dewey é a idéia de aprender fazendo, o trabalho cooperativo, a relação entre teoria e prática, o método de iniciar o trabalho educativo pela linguagem dos alunos. Mas para Paulo Freire as finalidades da educação são outras: sob uma ótica libertadora, a educação deve ligar-se à mudança estrutural da sociedade opressiva, embora ela não alcance esse objetivo imediatamente e muito menos sozinha (GADOTTI 1989).

A utilização da Aprendizagem Baseada em Problemas em conjunto com a educação com base na comunidade, a prática precoce em comunidade como o modelo do projeto UNI que une a universidade, os serviços e a participação real da população, podem de fato favorecer mudanças estruturais. Porém somente o emprego de uma metodologia inovadora não teria essa capacidade, aliás ela nem se propõe a isso.

Por outro lado, a aplicação da Aprendizagem Baseada em Problemas de uma maneira isolada não parece ser capaz de modificar a formação eminentemente biologicista verificada nos tutoriais observados na Escola do Novo México na Fase I, do no início do curso. Possivelmente isto também está relacionado à formação eminentemente biologicista dos tutores bem como com a experiência educacional dos alunos. Alguns docentes acreditam que tal questão pode ser mais bem trabalhada na prática, quando os alunos estão em contato com os pacientes. Para verificar se a prática médica pode propiciar maior entendimento do sofrimento humano e das necessidades de saúde, seria preciso um estudo mais aprofundado e uma pesquisa específica dirigida sobre o tema. Se não houver, porém, a redefinição do objeto do trabalho médico e a construção de um novo método de trabalho, que inclua diferentes campos do conhecimento para a compreensão biopsicossocial do ser humano, o uso de uma metodologia inovadora somente terá uma contribuição limitada.

\section{(3) a seleção e desenvolvimento de casos clínicos e as necessidades de saúde da comunidade}

A base da Aprendizagem Baseada em Problemas são os problemas, também denominados casos. Na mudança curricular ocorrida no Novo México em 1993, com a inclusão dessa metodologia, modificou a configuração do currículo por disciplinas. Com a adoção da $\mathrm{ABP}$, houve a necessidade de elaboração e seleção de casos que 
integrassem as ciências básicas e clínicas. Nesse processo, no afã de implantar o currículo misto, houve uma perda de qualidade nos novos casos, quando comparados com os casos iniciais do CCPS. Alguns dos novos casos escritos pelos docentes são mais estruturados e diretivos, provavelmente porque estes docentes tinham menos experiència com os fundamentos da nova proposta metodológica.

Uma das principais razões de isso acontecer foi a política interna da universidade. Os departamentos de ciências básicas eram em número de seis e na fusão curricular foram reorganizados para quatro departamentos, e não mais a partir de disciplinas, mas para um outro modelo, baseado em pesquisa temática. Desse modo, na fusão dos currículos havia, por parte de muitos docentes de ciência básica, uma sensação de perda das disciplinas tradicionais. Uma maneira de restabelecer a confiança entre os líderes educacionais e os cientistas básicos, e reassegurar a eles uma completa integração das cièncias básicas em ambas as Fases (I e II), ao longo dos anos clínicos, foi a criação de casos com conteúdos específicos.

No Novo México, apesar de todas as considerações feitas, não emergiram dali um conjunto de critérios para a seleção de casos. Cada chefe de bloco de ciência básica é livre para selecionar os casos que ele considera os mais importantes. Muitas vezes os casos foram escolhidos para enfatizar um tópico básico, que um docente particular achava estar sendo negligenciado. Não se pôde constatar uma visão de epidemiologia ou saúde pública na elaboração dos casos, ou seja, a partir dos principais problemas de saúde do Estado, pelo menos nos casos da Fase I. Apesar disso, comparando-se os principais problemas de saúde do Estado com a lista de casos da Fase I, observou-se que alguns problemas de saúde de grande importância no Novo México, como diabetes, alcoolismo, acidentes de automóvel com trauma, cardiopatias, problemas psíquicos, são temas dos casos do currículo daquele Estado.

O estabelecimento de critérios para a elaboração dos casos, como realizado em outras universidades que trabalham com ABP, parece ser um ponto importante para que não se reproduzam os mesmos problemas da pedagogia tradicional, em que os docentes tendem a ensinar com maior ênfase apenas os conteúdos que são seu objeto de pesquisa, por exemplo.

Com relação aos critérios, foram observados na literatura dois distintos aspectos relacionados aos critérios para a construção de um caso. Existem trabalhos, 
como o de MAC DONALD (1997), que sugerem os critérios para estabelecer as prioridades dos problemas de saúde com base na magnitude do problema (caso), na letalidade, na qualidade de vida, na severidade, na urgência, na preventibilidade, e na possibilidade de fazer diagnóstico e tratamento.

CAPRARA (2001), coloca que muitos autores apresentam diferentes critérios para a construção do caso ou problema como um aspecto essencial da Aprendizagem Baseada em Problemas. Por exemplo: estimular os estudantes ao desenvolvimento de hipóteses, coleta e interpretação de dados e à decisão diagnóstica e terapêutica, ser relevante quanto ao tema e aos objetivos educativos; ser pertinente ao nivel dos estudantes; ter uma seqüência lógica, motivar os estudantes a aprofundar a temática, ser adequado ao conteúdo abordado - são os diferentes aspectos que podem ser levados em conta na construção de um caso.

Ainda que se defina que os currículos de educação médica devam ter como objeto de estudo as necessidades de saúde da comunidade (como está preconizado, por exemplo, no relatório da CINAEM (2000) e nas Diretrizes Curriculares Nacionais aprovadas em 2001), o que se observou no currículo da UNM não foi conclusivo. Na percepção de alguns de seus docentes, as necessidades de saúde da comunidade são dificeis de ser problematizadas no currículo. Outros consideram que a prática médica é suficiente para fazer com que os estudantes se familiarizem com essas necessidades; e outros ainda ponderam que este não deveria ser o objeto de estudo do aluno de medicina.

Parece ser inegável a importância do currículo que tenha como objeto as necessidades de saúde da população, especialmente se o entendimento que se tem de currículo é o preconizado por MOREIRA e SILVA (1994), de que ele não é um elemento neutro e inocente de transmissão do conhecimento social, mas tem uma história vinculada a formas específicas de organização da sociedade. Tanto os casos escolhidos como problemas quanto as necessidades de saúde da comunidade podem ampliar o entendimento do estudante quanto à cidadania, responsabilidade $\mathrm{e}$ compromisso social para com a sociedade da qual ele faz parte.

Quanto às necessidades de saúde individuais e da comunidade, o que foi referido como importante pelos docentes foi a falta de acesso da população aos cuidados de saúde e a impossibilidade das pessoas (aproximadamente $30 \%$ da 
população) pagar seguro-saúde. Os problemas citados como os mais importantes no Novo México pelos docentes foram a pobreza, a falta de emprego e a exclusão social, que estão relacionados com a violência, o alcoolismo, o diabetes, o câncer e a gravidez na adolescência, fatos comuns no Estado.

Ainda articulando as necessidades de saúde, conforme relatadas pelos docentes com os casos em Fase I e II, observa-se que eles poderiam ser mais bem representados nos casos. Existem problemas de saúde de comunidade que aparecem nos casos eventualmente mas eles não são o enfoque central do caso.

Aparentemente os professores de ciência básica estão predominantemente preocupados com o conteúdo que consideram negligenciado. Os especialistas sabem mais de cuidado terciário e não estão habitualmente em comunidades nem lidando diretamente com problemas de cuidados primários. Desse modo, quando eles participaram da construção do currículo e do desenvolvimento de casos, criaram casos sobre sua própria especialidade. A ausência de critérios claros para a seleção de casos criou tal situação que não chega a ser surpresa o fato dos casos não cobrirem a maioria dos principais problemas do Estado.

\section{(4) a formação, o envolvimento e a participação dos docentes;}

As universidades da área da saúde normalmente têm uma grande tradição na produção de publicações, estudos avançados, na descoberta de novos conhecimentos e suas aplicações para os problemas. Isso é bastante evidente em pesquisa básica e clínica, porém o mesmo não ocorre quando se trata de pedagogia e metodologia educacional. Os professores não aceitariam um protocolo de pesquisa que não fizesse uso dos melhores e mais contemporâneos métodos da ciência. Também não iriam aceitar um padrão de cuidados que não usasse as terapias e os medicamentos mais efetivos e atuais. Porém é muito mais comum que os professores - ignorando o pensamento educacional, os novos métodos e a pesquisa em educação - continuarem a utilizar a pedagogia tradicional do que aplicarem novas idéias em sua prática.

Uma mudança positiva, fruto da fusão curricular, foi o desenvolvimento de novas habilidades e a criação de canais de discussão dos docentes a respeito da educação na UNM. 
O Novo México tem uma longa tradição de desenvolvimento de docentes em educação. Isso começou com a adoção de ABP em 1979, quando foi realizado um treinamento para que professores trabalhassem em grupos pequenos $\mathrm{e}$ desenvolvessem materiais pedagógicos transdisciplinares. A diversificação de encontros e a constante oferta de atividades são parte da estratégia de mudança. Podese observar que é preciso um trabalho lento e constante para que as mudanças sejam incorporadas.

Várias atividades são oferecidas ao longo do ano, em diferentes dias e horários, de modo que os docentes possam participar da realização dos cursos.

Os docentes num modelo como o da Escola de Medicina da UNM necessitam, para ser um bom facilitador, ter habilidades em técnicas de trabalho de grupo, além do dominio do conhecimento geral das questões envolvidas nos casos, como também na sua área de especialização.

A análise de documentos do Novo México mostrou que aconteceram e continuam acontecendo muitos seminários, reuniões, retiros, discussões e diálogos em todos os niveis na instituição. O significado de tanto investimento e oportunidades múltiplas é construir um amplo vocabulário compartilhado sobre educação e inovação que não existia antes, exceto talvez por alguns pedagogos e agentes de mudança. $E$ este vocabulário que permite uma sintaxe educacional para evoluir em inovação, que é institucional, ampla e permanente.

Baseando-se em observação direta desse fenômeno, foi abundantemente evidente que isso acontece em reuniões organizacionais de governabilidade, desenvolvimento de curriculo, avaliação e avaliação de programa. Os líderes da Escola de Medicina do Novo México acreditam que a ausência de um vocabulário compartilhado inibe o diálogo sobre a educação. Uma questão que fica clara é o caráter processual de formação dos docentes, pois apesar de todo investimento realizado nessa formação, ainda assim continua sendo necessário criar diferentes espaços de discussão, o que mostra quão forte é o pensamento cartesiano no qual todos somos formados.

Um significante e recente trabalho em educação no Novo México foi a criação de um programa específico para a formação e capacitação de futuros lideres em educação médica, o Programa de Estudos em Educação médica (MES), agora em seu 
terceiro ano de existência. O programa foi desenvolvido em colaboração com o diretor da Escola de Medicina, os chefes de departamento e o diretor assistente do setor de Desenvolvimento e Pesquisa Educacional. Até o momento, 22 docentes de cadeiras básicas e clínicas participaram do programa. A maioria dos membros dos comitês em educação médica estão nesse programa. Isso legitimou o trabalho em educação médica para os docentes e ampliou o prestígio de educação médica na escola. Os participantes do MES se inscrevem no programa e são selecionados conforme seu interesse, suas habilidades em contribuir para o desenvolvimento educacional da instituição, por suas afiliações departamentais. Os diplomados no programa são elegíveis para obter pequenos financiamentos do diretor e continuar a trabalhar em projetos de avaliação, desenvolvimento de docentes e liderança. Esses projetos acontecem em diversos programas, como, por exemplo, no de residência e nos estágios de graduação.

RUBECK e WITZKLE (1998) consideram o desenvolvimento do docente um aspecto fundamental da reforma curricular. O documento da CINAEM (2000) também coloca este fator como um dos eixos essenciais na transformação da educação médica no Brasil.

Porém, isso não acontece automaticamente e de um modo auto-organizado. A criação de um Setor de Desenvolvimento Educacional do Professor no Novo México, a criação de um Núcleo de Apoio Pedagógico em Londrina, ou a criação de um Centro de Desenvolvimento do Ensino Superior na UNIFESP e do Centro de Educação Médica na USP podem contribuir para ampliar a discussão sobre o futuro da Educação Médica no Brasil e para conseguir novos aliados, formar massa crítica para as reformas no ensino.

A longa tradição de desenvolvimento de docentes no Novo México não aconteceu somente na Escola de Medicina mas foi ampliada para todos os docentes do Centro de Ciências de Saúde (HSC), atendendo professores de diversas universidades americanas e estrangeiras. Essa tem sido uma das grandes contribuições do Novo México para a educação médica nacional e internacional. A oferta de seminários, debates, encontros e consultoria nacional e internacional em diversos países também os fortalece a continuar o próprio processo de mudança. 


\section{(5) e a avaliação como parte integral do processo de mudança e da aprendizagem.}

Outro aspecto importante nas escolas inovadoras é que o curriculo precisa continuar a ser avaliado e evoluir com o passar do tempo. Isso foi ilustrado na experiència da evolução de currículo do Novo México, de um currículo paralelo de quinze anos para um curriculo único em 1993, que buscou manter os melhores aspectos de ambos os programas.

No Novo México existem inúmeros documentos que se referem à avaliação de alunos. Em geral, eles revelam que uma quantia significante de energia de alguns docentes é dedicada a esse processo. No Novo México a avaliação é parte da aprendizagem e é utilizada formativamente para ajudar os alunos a melhorar sua performance. As avaliações são um outro momento de aprendizagem e de ajuda em relação aos aspectos em que os estudantes demonstram dificuldades. Semelhantes abordagens de avaliação acontecem em outras escolas, como a Universidade de Illinois e a de Marília no Brasil

$\grave{E}$ interessante ressaltar que os exames nacionais e estaduais americanos ainda se baseiam na pedagogia tradicional, cuja preocupação está centrada na memorização de fatos e nos conteúdos de ciência básica. Para BARROWS (1996), a maior ironia é que os procedimentos de avaliação formal não são capazes de distinguir os alunos que estudam no curriculo tradicional e os de ABP, pois os exames são insensiveis quanto às diferenças cognitivas e comportamentais que são observadas na $\mathrm{ABP}$. Os estudos de metaavaliação realizados por ALBANESE e MITCHELL (1993) mostram que os estudantes na $\mathrm{ABP}$ se saem bem nos exames tradicionais, e tem mais habilidades de resolver problemas clínicos, além de se sentirem estimulados e motivados com o método.

A avaliação de programa também está bem desenvolvida no Novo México e monitora a performance de alunos em exames internos e em exames externos como o USMLE, parte 1, 2, 3. A fonte de informações para melhorar o programa é derivada de avaliações internas a respeito do desenvolvimento de habilidades, integração crítica de conhecimento, habilidades clínicas, atitudes e valores e ética profissional, auto-avaliação e comunicação. Só as primeiras duas habilidades são avaliadas pelo USMLE parte 1-3. Desse modo, os dados internos são mais completos na avaliação 
de programa. Se a avaliação mostra como o aluno está aprendendo, então a avaliação de programa mostra como está o currículo. A avaliação de programa é conduzida por um grupo especificamente dedicado a este trabalho. Eles realizam muitos grupos focais, entrevistas e pesquisas durante o ano todo, com alunos desde o primeiro ano até os médicos formados. As informações são analisadas e divulgadas regularmente para toda administração e faculdade. Este processo mantém o currículo em crescente desenvolvimento.

Do ponto de vista do programa, as avaliações internas e as comparativas com os exames nacionais são realizadas e utilizadas como uma avaliação indireta do currículo. Os resultados obtidos são empregados na implementação e modificação do currículo. Isso está de acordo com a avaliação permanente das inovações realizadas do projeto UNI como um instrumento importante para evidenciar e propiciar a construção de mudanças mais amplas (FEUERWERKER e SENA 1999).

Todos esses aspectos levantados e discutidos podem colaborar no desencadeamento de processos de reforma curriculares no ensino médico aqui no Brasil, na orientação e no formato que podem assumir nas escolas médicas. Nos ajudam principalmente a refletir sobre como estamos desenvolvendo os processos de formação não só dos médicos mas de todos que estão ou não no ensino universitário. Cientista, educadores e pesquisadores já há muito tempo vem questionando a superespecialização e a fragmentação do conhecimento que não ajuda a resolver os complexos e multifacetários problemas do nosso tempo. A educação fundamentada nessa mesma prática hegemônica já começa a ser revisto e questionado no nosso país, mas a resistência ainda é muito grande.

A possibilidade de realização desse estudo e seus resultados embora limitados puderam contribuir para aqueles interessados em desenvolver práticas semelhantes aqui ou em outros locais. 


\section{Capítulo 6 Conclusões e considerações fínais}




\section{Capítulo 6 - Conclusões e considerações finais}

Diversas escolas no Brasil e no mundo estão realizando um processo de mudança curricular, este é um período de intensa aprendizagem e troca de experiências entre diferentes escolas de medicina nacionais e internacionais no que diz respeito a melhorar a formação dos médicos.

O estudo da reforma curricular da Escola de Medicina da Universidade do Novo México (EM-UNM) mostrou que momento político expresso através da insatisfação dos docentes e da necessidade de formar mais médicos em cuidados primários em saúde para o Estado. A correlação de forças internas e externas foram os fatores motrizes para a realização da reforma curricular.

Alguns docentes lideraram o processo e foram capazes de aproveitar as forças convergentes que integradas garantiram a discussão e a realização de uma reforma curricular que culminou com a introdução de um educação médica (CCPS).

A estratégia utilizada na primeira mudança curricular da EM-UNM foi a realização de um projeto-piloto até que houve a possibilidade de fundir os dois currículos num só. Então, foi necessário um grande trabalho por parte dos líderes envolvidos no CCPS para com os outros docentes, até que houvesse massa crítica com envolvimento e experiência para trabalhar em conjunto.

A utilização do projeto-piloto permitiu aos participantes um período de tempo em que foi possivel buscar, experimentar e aprender melhores estratégias na formatação do currículo. Ou seja, houve tempo para desenvolverem habilidades e testarem novas possibilidades para o currículo de cuidados primários, que foram posteriormente utilizadas no currículo atual.

Por outro lado, os lideres do CCPS consideraram uma falha terem mantido dois currículos separados por um período tão longo de tempo e avaliaram que deveriam ter realizado a fusão de ambos mais cedo. Quando houve a fusão dos dois currículos, muitos professores não estavam preparados e até eram contra um modelo inovador. Foi necessário um grande período de negociações, que perdura até o presente momento, no qual se perderam aspectos significativos do curriculo de cuidados primários para que se pudesse realizar a fusão. 
Liderança e governabilidade foram as palavras-chave dos líderes no processo de fusão dos currículos. Houve a preocupação de conseguir o envolvimento da maior parte dos docentes e dos dirigentes, por meio de um intensivo trabalho de discussão e preparação para as mudanças pretendidas. Durante o processo de desenvolvimento do novo currículo foram criados comitês para que houvesse uma ligação entre o pessoal envolvido nas mudanças e os que foram se envolvendo gradativamente. É importante ressaltar o sentido de processo na reforma curricular, pois as negociações continuam a acontecer nos comitês da escola de medicina. O gerenciamento e a implementação do currículo são de responsabilidade do diretor da graduação médica e dos comitês (Comitê do Currículo e Grupo de Integração) a ele subordinados. Este diretor tem maior ou menor poder, de acordo com a correlação de forças entre os departamentos e da atuação do diretor da EM-UNM junto a estes departamentos.

O currículo atual da UNM é um currículo misto, no qual convivem aulas ou conferências tradicionais e aspectos inovadores como a integração interdisciplinar e transdepartamental das ciências básicas e das ciências clínicas através da Aprendizagem Baseada em Problemas, da educação orientada à comunidade, da inserção precoce do aluno da prática e da diversidade de instrumentos de avaliação. $O$ esforço realizado para organizar o curriculo integralmente e não como a justaposição de disciplinas independentes foi um aspecto fundamental observado nesse estudo, inclusive com a fusão de dois departamentos de ciências básicas por área temática.

A metodologia de aprendizagem ativa em pequenos grupos e a prática precoce em comunidade, constante ao longo da graduação, o sistema de avaliação como parte fundamental do processo educativo e a atuação do docente como facilitador são aspectos bastante diferentes quando comparados com a pedagogia tradicional, em que o conteúdo é disciplinar, o aluno é passivo e o docente é o detentor do saber.

Não foi possível, entretanto, saber se existe um componente da proposta metodológica que é mais importante, ou se realmente é a combinação de todos seus componentes que influencia a escolha dos estudantes em carreiras de cuidados primários em saúde. Pôde-se depreender, porém, pelo vigor com que os professores referiram, que a prática precoce em comunidade seja um aspecto primordial na formação dos alunos. $O$ que se pode observar é que os alunos mostram-se muito felizes ao iniciar o trabalho prático desde a primeira semana do curso de medicina. 
A utilização da Aprendizagem Baseada em Problemas, que tem suas limitações, aliás inerentes a qualquer abordagem pedagógica, é uma metodologia extremamente promissora quanto à capacidade de integrar os diferentes campos do saber e de propiciar ao aluno a possibilidade de ser sujeito na construção do conhecimento

Por outro lado, a Aprendizagem Baseada em Problemas não parece ser capaz de modificar a formação eminentemente biologicista verificada nos tutoriais por dois motivos: pelo modo com que alguns casos são elaborados e pela formação biologicista dos próprios docentes. A ausência de critérios para a seleção dos casos vai se refletir nos objetivos de aprendizagem que são estabelecidos em cada um dos casos e no conteúdo ensinado.

O estabelecimento de critérios para a elaboração dos casos, como realizado em outras universidades que empregam a $\mathrm{ABP}$, parece ser um ponto importante para que não se reproduzam os mesmos problemas da pedagogia tradicional, em que os docentes tendem a dar mais ênfase nos conteúdos que são seu objeto de pesquisa, por exemplo. Nesse sentido seria importante a definição de uma comissão responsável por analisar e revisar os casos periodicamente através de critérios preestabelecidos.

A prática precoce é um ganho positivo em termos de currículo, pois tem início na primeira semana do curso e se estende com uma complexidade crescente até o último ano da graduação, permitindo que o estudante possa ficar um tempo bastante extenso em contato o paciente.

Para verificar se a prática precoce pode propiciar maior entendimento do sofrimento humano e das necessidades de saúde de uma maneira menos biologicista, seria necessário um maior aprofundamento e uma pesquisa dirigida especificamente para esta questão.

Há uma grande diversidade de cenários de aprendizagem na EM-UNM bem como um trabalho constante de avaliação dos preceptores.

Ainda que se defina que os currículos de educação médica devem ter como objeto de estudo as necessidades de saúde da comunidade o que se observou no currículo da UNM não foi conclusivo. Na percepção de alguns docentes da UNM, as necessidades de saúde da comunidade são dificeis de serem incluídas no currículo. Outros consideram que a prática médica é suficiente para fazer com que os estudantes 
se familiarizem com essas necessidades; e outros ainda consideram que este não deveria ser o objeto de estudo do aluno de medicina.

Outro resultado é a atenção que é dada à avaliação do estudante e à avaliação do programa, vistas como um momento de aprendizagem e de ajuda nos aspectos em que os estudantes demonstram dificuldades, a fim de melhorar seu desempenho em áreas do conhecimento que apresentam lacunas.

Do ponto de vista do programa, as avaliações internas e as comparativas com os exames nacionais são utilizadas como uma avaliação indireta do currículo. Os resultados obtidos são empregados para a implementação e modificação do currículo.

Sugere-se que, dadas a diversidade e riqueza das formas de avaliação e a quantidade de momentos dedicados a isso, a avaliação dos estudantes e do programa seja objeto de uma pesquisa única e aprofundada.

Chamou a atenção o investimento dado à formação dos docentes, como a diversificação de encontros e a constante oferta de atividades que são parte da estratégia de mudança. Pode-se observar que é preciso um trabalho lento e constante para que as mudanças sejam incorporadas e se diminua a resistência ao novo currículo.

Outro aspecto de extrema importância observado foi a participação ativa dos docentes nos fóruns semanais de discussão dos aspectos teóricos que embasam cada um dos casos. Esta atividade possibilita o encontro de docentes que num currículo tradicional passariam longo tempo sem se reunir para debater.

Outra percepção com relação aos docentes diz respeito ao nivel de envolvimento e compromisso do grupo de docentes do Departamento de Medicina Familiar e Comunitária. Embora sejam em número pequeno, sempre participam das três fases dos tutoriais, comparecem às reuniões, participam ativamente dos seminários e das oficinas de trabalho de educação médica. Estes docentes são também os preceptores dos estudantes nos estágios de desenvolvimento de habilidades clínicas, nas clínicas comunitárias e na experiência de imersão dos estudantes na prática clínica.

A revisão contínua e periódica do programa de educação médica, como a que está sendo realizada atualmente, é muito importante, uma vez que a implementação 
está sendo realizada atualmente, é muito importante, uma vez que a implementação das mudanças vem fazendo com que mais docentes participem e trabalhem na melhoria do currículo.

As novas mensagens que emergem do pensamento e da prática contemporânea revelam que o paradigma newtoniano-cartesiano já não serve para a pesquisa e o ensino universitário, dada a complexidade atual. Como mudar a tradição de análise na ciência atual enquanto é necessária um mudança em direção aos benefícios de síntese? Como adotar uma perspectiva ecológica profunda e desenvolver economias, comunidades e práticas educacionais sustentáveis? Como educar os educadores de modo mais sistêmico, gerando intelectuais polivalentes e capazes de investir sobre a cultura em seu sentido mais amplo? As implicações dessas novas idéias para a formação dos estudantes e o desenvolvimento de docentes são aspectos que merecem uma reflexão profunda. Essa mudança de paradigma exige novas habilidades, novos pontos de vista e a recriação dos arcabouços atuais de pensamento.

Nesse sentido, além da reforma curricular, é necessária uma reforma do pensamento.

Para Morin, a reforma do pensamento é uma necessidade democrática fundamental: formar cidadãos capazes de enfrentar os problemas de sua época, é frear o enfraquecimento democrático que suscita, em todas as áreas da política, a expansão da autoridade dos expertos, especialistas de toda ordem, que restringe progressivamente a competência dos cidadãos. A reforma do ensino deve levar à reforma do pensamento e a reforma do pensamento deve levar à reforma do ensino $e$ este é o desafio dos desafios. (MORIN 20001). 
Referências 
Aguiar, AC. Consequences for Faculty of Changes in Medical Education: the Experience of Tutoring a Course About the Patient-Doctor Relationship. Cambridge, MA. [Tese apresentada à Harvard Graduate School of Education].

Aguiar AC. Implementando as novas diretrizes curriculares para a educação médica: o que nos ensina o caso de Harvard? Interface: Comunicação Saúde Educ 2001; 5(8): $161-166$.

Albanese MA, Mitchell S. Problem-based learning: A review of literature on its outcomes and implementation issues. Acad Med 1993; 68:52-81

Almeida MJ. Educação médica e saúde - Possibilidade de mudança. Londrina: UEL; 1999.

Almeida $F^{o}$ N. Transdisciplinaridade e saúde coletiva. Ciencia \& Saúde Coletiva. $19972(1 / 2): 5-20$.

Anderson MB A guide to the 130 reports in this snapshot supplement to Academic Medicine. Acad Med 2000; 75 (9): b.

Arouca AS. O dilema preventivista: contribuição à crítica da medicina preventiva. Campinas; 1975 \{Tese de doutorado- Universidade de Campinas].

Barrows HS. Problem-based learning in medicine and beyond: a brief overview In: Wilkerson L, Gijselaers WB. (eds.) New directions for teaching and learning. bringing problem-based learning to higher education: theory and practice. San Francisco: Jossey-Bass Publishers; 1996. (68): p.3-21.

Barrows HS. A taxonomy of problem-based learning methods. Med Educ 1986; 20: 481-486.

Batista NA, Silva SHS. O professor de medicina conhecimento, experiência e formação. São Paulo: Loyola; 1998.

Berbel NAN. Currículo médico e compromisso social. Divulgação saúde debate 1994; 9: 59-64.

Berlinguer G. Globalização e saúde global. Estudos avançados 1999;13(35):21-38.

Bligh J. Problem - based learning in medicine: an introduction. Postgrad Med Journal 1995: 71(836): 323-326.

Bloom SW. The medical school as a social organization: the sources of resistance to change. Med Educ 1989; 23: 228-241.

Boaden N, Bligh J. Community-based medical education: towards a shared agenda for learning. London: Amold; 1999.

Brasil Constituição da República Federativa do Brasil. São Paulo: IMESP; 1988. 
Byrne N, Rosenthal M. Tendências Actuales de la Educación Médica y Propuesta de Orientación para la Educacion Médica en America Latina. Educ Med Salud 1994; 28:53-92

Campos J.Q. Evolução histórica da questão saúde. In: Introdução à saúde pública. São Paulo. 1987.

Capra F. O ponto de Mutação.São Paulo: Editora Cultrix; 1982

Capra F. A teia da vida. São Paulo: Cultrix, 1996. -

Caprara A. A construção narrativa de problemas. In: Mamede S e Penaforte J. (org.), In: Mamede $S$ e Penaforte J. (org.), Aprendizagem baseada em problemas. $1^{\text {a }}$ ed.São Paulo. Hucitec, 2001. p. 142-156.

Carvalheiro JR. Os desafios para a saúde. Estudos avançados 1999; 13 (35):7-20.

Castro LP, Salgado JA. A ABEM e a perspectiva de reestruturação da saúde e da educação médica. Rev Bras Educ Med 1987; 11(3): 73-140.

Chaves, MM. Algumas reflexões sobre IDA: antecedentes do ideário UNI.

Divulgação saúde debate 1994; (9):.5-9.

Comissão Interinstitucional Nacional de Avaliação do Ensino Médico Preparando a transformação da educação médica brasileira : projeto CINAEM III fase: relatório 1999-2000. Piccini RX.; Facchini LA.; Santos RC. Orgs. Pelotas: UFPel, 2000 .

Cortella MS. A Escola e o Conhecimento - fundamentos epistemológicos e políticos. São Paulo: Cortez; 1998.

Cortes MT, Kaufman A, Sanchez GB, Bennet MD, Ortiz-Huerta D, Martinez-Burrola $\mathrm{N}$, Alonso CS e Durazo L. Community-oriented medical education: comparison of tracks in Mexico and New Mexico. Med Educ 1985; 19: 199-207.

Demo P. Educação e qualidade. $2^{a}$ ed. Campinas: Papirus, 1995.

Des Marhais JE., Bureau MA., Dumais B. e Pigeon G. From traditional to problem based learning: a case report of complete curriculum reform. Med Educ 1992; 26(3): 190-199.

Donnangello C. A pesquisa da área da saúde coletiva no Brasil- a década de 70 In: Abrasco Ensino da Saúde Publica Medicina Preventiva e Social no Brasil 1983; 2:18-35

Donnangelo MCF, Pereira L. Saúde e Sociedade. São Paulo: Duas Cidades; 1976.

Dutra de Oliveira JE. Educação médica e assistência médica. Rev Ass Med Brasil 1993; 39(4): 194-196. 
Ferreira, JR. Apresentação In: Organização Panamericana da Saúde Contribuições sobre a gestão de qualidade em educação médica Brasil, 1994 (OPAS - Serie Desenvolvimento de Recursos Humanos, 7)

Feuerwerker LCM, Marsiglia R. Estratégias para mudanças na formação de RHs com base na experiência IDA/UNI. Divulgação saúde debate 1996;(12): 24-28.

Feuerwerker LCM. Mudanças na educação médica e residência médica no Brasil. São Paulo: Hucitec; 1998.

Feuerwerker LCM, Sena R.M. A construção de novos modelos acadêmicos, de atenção à saúde e de participação social. In: Almeida $M$. et al., org. A educação dos profissionais de saúde na América Latina. São Paulo: Hucitec; 1999.p. 47-82.

Fleury S. Equidade e reforma sanitária: Brasil. Saúde Debate 1994; (43): 44-52.

Flexner A. Medical Education in the United States and Canada. A report to the Carnagie Foundation for the Advancement of Teaching. New York City: Fifth Avenue; 1910.

Freitag B. Escola, estado e sociedade. $4^{\mathrm{a}}$ ed. São Paulo: Moraes; 1980.

Friedman CP, Bliek, R, Greer DS, Mennin SP, Norman, GR, Sheps CG, Swanson $\mathrm{DB}$, Woodward CA. Charting the winds of change: evaluating innovative medical curricula, Acad Med 1990; 8-14. (special article)

Fundação Oswaldo Cruz. Gestão de saúde: curso de aperfeiçoamento para dirigentes municipais de saúde: programa de educação à distância. Rio de Janeiro: Fiocruz; Brasilia: UNB, 1998

Gadotti M. História das idéias pedagógicas. $3^{\mathbf{a}}$ ed. São Paulo: Ática; 1995.

Gijselaers WH. Conneting problem-based practices with educational theory. In: Wilkerson L, Gijselaers WB. (eds.) New directions for teaching and learning. bringing problem-based learning to higher education: theory and practice. San Francisco: Jossey-Bass Publishers; 1996. (68): p. 13-22.

Giles TR. Filosofia da Educação. $2^{a}$ ed. São Paulo:Epu, 1983.

Glick SM. Problem-based learning and community-oriented medical education. Med Educ 1991; 25: 542-545

Gonçalves EL. Evolução do ingressante da escola médica do Brasil com vistas ao atendimento da comunidade brasileira. Rev Bras Educ Med 1990; 14(1): 1-32.

Silva G. R. Origens da medicina preventiva como disciplina do ensino médico. Rev. Hosp. Clin. Fac. Med. S. Paulo 1973: 28: 91-96.

Ianni O. Teorias da globalização. $2^{a} e d$. Rio de Janeiro: Civilização Brasileira, 1996. 
Ianni O. Globalização e transculturação. Primeira versão 1997; (69) IFC/UNICAMP.

Iriart $\mathrm{C}$, Merhy $\mathrm{E}$, Waitzkin $\mathrm{H}$. La atención gerenciada en America Latina transnacionalización del sector salud en el contexto da reforma Cad Saúde Pub 2000; 16(1): 95-105.

Ito AMY. Estratégias de reforma da educação dos profissionais de saúde na UEL. Divulgação saúde debate 1994; (9): 55-58.

Kantrowitz M, Kaufman A, Mennin S, Fulop T, Guilbert JJ. Innovative tracks at established institutions for education of health personnel. An experimental approach to change relevant to health needs. WHO Offset Publ. 1987; (101):3-232.

Kaufman A, Klepper D, Obenshain S, Voorhees JD, Galey W, Duban S, Moore-West M, Jackson R, Bennet M, Waterman R. Undergraduate Medical Education for primary care: a case study in New Mexico. South Med J 1982 75(9): 1110-1117.

Kaufman A. editor. Implementing problem-based Medical Education: Iessons from sucessful innovations. New York. Springer, 1985

Kaufman A, Mennin S, Waterman R, Duban S, Hansbarger C, Silverblatt H, Obenshain S, Kantrowitz M, Becker T, Samet J, Wiese W. The New Mexico Experiment: Educational Innovation and Institutional Change. Acad Med 1989; S285-S294

Kaufman A, Obenshain SS, Voorhees JD, Burrola NJ, Christy J, Jackson R, Mennin S, The New Mexico Plan. Pub Health Reports 1980; 95(1): 38-41

Kaufman A. Rurally Based education:confronting Social Forces Underlying Ill Health. Acad Med 1990; 65 (12): S18-S21.

Komatsu RS, Zanolli MB, Lima VV. Aprendizagem Baseada em Problemas. In: Marcondes E, Gonçalves EL., editores. Educação médica São Paulo: Savier;1998.

Lasker, RD. Previous Attempts to bridge the gap between medicine and public health In Medicine \& public health: the power of collaboration. The New York Academy of Medicine, New York, 1997.

Lefèvre F, Lefèvre AMC. Novas abordagens metodológicas em pesquisa qualitativa. São Paulo: Faculdade de Saúde Pública da USP; 1999.

Lefèvre F, Lefèvre AMC, Teixeira JJV. O discurso do sujeito coietivo: uma nova abordagem metodológica em pesquisa qualitativa. Caxias do Sul: EDUCS,2000.

Libâneo JC. Democratização da escola pública: a pedagogia crítico-social dos conteúdos. $3^{\mathrm{a}}$ ed. São Paulo: Loyola; 1986. 
Lima VV., Komatsu RS. UNI Marilia: possiveis efeitos sobre as políticas educacionais. In: Almeida $\mathrm{M}$. et al., org. A educação dos profissionais de saúde na América Latina. São Paulo: Hucitec; 1999.p. 119-123

Losada LS. e Angulo J. M., La epistemologia y sus desafios para el dia de hoy. Map internacional, 1999 , América Latina.

Lopes-Pontes JP. Ensino médico no Brasil: evolução, perspectivas e desafios. Rev Bras Educ Med 1982; 6(2): 104-6.

Ludke M, André, MEDA. Pesquisa em educação: abordagens qualitativas. São Paulo: EPU; 1986.

Machado JLM, Caldas ALJ, Bertoncello NMF. Uma nova iniciativa na formação de profissionais de saúde. Interface: Comunicação Saúde Educ 1997; 1(1): 147-156.

Mac Donald PJ. Selection of health problems for a problem-based curriculum in: Boud D and Feletti GI (ed). The challenge of problem based learning 2 ed Kogan Page London 1997

Mamede S e Penaforte J. (org.), In: Mamede S e Penaforte J. (org.), Aprendizagem baseada em problemas. I $^{\mathrm{a}}$ ed. São Paulo. Hucitec, 2001

Marsiglia RG. Relação ensino-serviços: dez anos de integração docente assitencial (IDA) no Brasil. São Paulo: Hucitec; 1995.

Mendes R. Cidades saudáveis no Brasil e os processos participativos: os casos de Jundiaí e Maceió. São Paulo: 2000 [Tese de doutorado - Faculdade de Saúde Pública da USP]

Mennin SP, Friedman M, Skipper B, Kalishman S, Snyder J. Performances on the NBME I, II and III by medical studens in the problem-based learning and conventional tracks at the University of New Mexico. Acad Med 1993; 68(8): 61624.

Mennin SP, Friedman M, Woodward CA. Evaluating innovative medical education programmes:common questions and problems. Annals Com-Or Educ 1992; 5:12333.

Mennin SP, Kalishman S, Friedman M, Pathak D, Snyder J. A survey of graduates in practice from the university of New's Mexico conventional and community-oriented problem -based tracks. Acad Med 1996; 71(10):1079-89.

Mennin SP, Kalishman. Student Assessment. Acad Med 1996; 73(9):S46-54.

Mennin SP, Kaufman A. The change process and medical education. Med Teacher 1989; 11(1): 9-16. 
Mennin Sp, Krackov SK. Refletions on relevance, resistence, and reform in medical education. Acad Med 1998; 73(9): S60-4.

Merhy E. Alma Ata: qual é o jogo? \{apostila mimeo] s/d.

Construindo uma cartografia da escola médica e pensando nós críticos para a gestão da mudança. Campinas; 1999. [Apostila desenvolvida no Departamento de Medicina Preventiva e Social / Faculdade de Medicina / Universidade de Campinas]

Miles MB, Huberman AM. Qualitative data analysis: an expanded sourcebook. $2^{\text {nd }}$ ed. Thousand Oaks, California; 1994.

Minayo MCS. $O$ desafio do conhecimento: pesquisa qualitativa em saúde. $3^{\text {a }}$ ed. São Paulo: Hucitec; 1994.

Ministério da Saúde. Conferência Nacional da Saúde In: Anais da $8^{\mathbf{a}}$ Conferência Nacional da Saúde. 1986; Brasília, Brasil. Brasilia: Centro de documentação da Saúde; 1987. 430p.

Mizukami MGN. Ensino: as abordagens do processo. São Paulo: EPU, 1986.

Moore-West M, Harrigton DL, Mennin SP Kaufman A, Skipper B. Distress and attitudes toward the learning enviroment: effects of curriculum innovation Teaching Learning Med, 1989; 1(3): 151-7.

Moreira AF, Silva TT. Currículo, cultura e sociedade. $3^{\mathrm{a}}$ ed. São Paulo: Cortez, 1999.

Morin E., A cabeça bem-feita: repensar a reforma, reformar o pensamento. $4^{\mathrm{a}}$ ed., Rio de Janeiro: Bertrand Brasil, 2001

New Mexico Departament of Health. 1998 selected statistics:annual report. Santa Fé; 2000 (a).

New Mexico Departament of Health. The state of health in New Mexico: 1999 report. Santa Fé; 2000 (b).

Nunes E.D. Saúde Coletiva: história e paradigmas. Interface-comunicação, saúde, educação 1998 2(3) 107-16.

Obenshain S, Mennin S. University of New Mexico School of Medicine. Acad Med $2000 ; 75(9)$ : S225-27.

Oliveira EM. A mulher, a sexualidade e o trabalho. São Paulo: CUT; 1999.

OMS/UNICEF. Atención primária de salud, Alma Ata (1978). Genebra

Organización Panamericana de la Salud. Encontro continental de educación médica. Punta del Este; 1994.(OPAS - Serie Desarollo de Recursos Humanos, 102). 
Organização Panamericana de la Salud. Enseñanza de la medicina preventiva y social: 20 años de experiência latinoamericana. Informes de los seminários de Viña del Mar, Chile (1955) y Tehuacán, México (1956). Publicacion cientifica nº 324

Paim J. S. Desenvolvimento Teórico-conceitual do ensino em Saúde Coletiva. In: Abrasco Ensino da Saúde Publica Medicina Preventiva e Social no Brasil 1982; 1:517.

Paim JS. Recursos humanos em saúde no Brasil: Problemas crônicos e desafios agudos. São Paulo: Faculdade de Saúde Pública /USP; 1994.

Patton MQ. Qualitative evaluation methods. London: Sage Publications; 1987.

Penaforte J. John Dewey e as raizes filosóficas da aprendizagem baseada em problemas In: Mamede S e Penaforte J. (org.), Aprendizagem baseada em problemas. $1^{a}$ ed.São Paulo. Hucitec, 2001. p. 49-77.

Regan-Smith MG. Reform without change: update, 1998. Acad Med 1998, 73(5): $505-7$

Rego S. Currículo paralelo em Medicina, experiència clinica e PBL: uma luz no fim do túnel? Interface: Comunicação Saúde Educ 1998; 2(3): 35-48.

Rodrigues-Neto E. Alternativas transformadoras na educação médica latinoamericana. Rev Bras Educ Med. 1987; 11(2): 37-8.

Romanelli OO. História da educação no Brasil (1930/1973). $8^{\mathrm{a}}$ ed. Petropolis: Vozes; 1986.

Rosen, G. A evolução da medicina social. In: Nunes EV. Org. Medicina Social, aspectos históricos e teóricos. $1^{a}$ ed. Sãp Paulo: Global Ed, 1983 p.25-82.

Rubek RF, Witzkle, DB. Faculty development: a field of dreams Acad Med 1998, 73(9): S32-7.

Santos BS. Pela mão de Alice $4^{a}$ ed. São Paulo: Cortez; 1997.

Santos JL, Westphal MF. Práticas emergentes de um novo paradigma de saúde: 0 papel da universidade Estudos Avançados 1999; 13(35): 71-88.

Savery JR; Duffy TM. Problem based learning; an instructional model and its construtivism framework. Educ Technol 1995 sept/oct: 31-37.

Saviani D. Escola e democracia. $15^{\mathrm{a}}$ ed. São Paulo: Cortez: 1987

Schmidt HG. Foundations of problem-based learning: some explanatory notes. Med Educ 1993; 27(5): 42-423. 
Schmidt H. As bases cognitivas da aprendizagem baseada em problemasin: Mamede $\mathrm{S}$ e Penaforte J. (org.), Aprendizagem baseada em problemas. $1^{\text {a }}$ ed. São Paulo. Hucitec, 2001. p.80-108.

Schraiber LB. O médico e seu trabalho, limites da liberdade. São Paulo: Hucitec; 1997.

Schraiber LB. Contribuição ao estudo da educação médica. São Paulo; 1980 [Dissertação de mestrado - Faculdade de Medicina da USP].

Sheline B, Small B, McCollum S, Gorby M, Schuster T, Mennin S, Kaufman A, Health of the public: New Mexico's next innovation in medical education. Teaching Learning Med 1990; 2(3): 170-5

Silva T. T, organizador. Teoria educacional crítica em tempos pós-modernos. Porto Alegre: Artes Médicas Sul, 1993.

Silva GR. Origens da medicina preventiva como disciplina do ensino médico. Rev. Hosp. Clin. Fac.Med. S. Paulo 1973; 28: 91-96.

Sobral DT. Aprendizagem baseada em problemas: efeitos no aprendizado Rev Bras Educ Med 1994; 18(2): 61-2.

Sobral DT. Três casos de inovação curricular no panorama recente (1964-1988) da educação médica brasileira: subsídios de um retrospecto baseado na revisão de documentos. Rev Bras Educ Med 1991; 15(9): 1-32.

Spaulding, WB. The undegraduate medical curriculum (1969 model): Mc master UniversityCanad. Med. Ass. J. 1969;100(12): 659-664.

Stern BJ. A saúde das cidades e o primeiro movimento de saúde pública In: Nunes EV. Org. Medicina Social, aspectos históricos e teóricos. $1^{a}$ ed. Sãp Paulo: Global Ed, 1983.p. 83-94

Teixeira C. Departamento de medicina preventiva e social: concepção e práticas. [Apresentado ao Encontro "Medicina Preventiva e Assistência a Saúde possíveis caminhos" Depto de Medicina Preventiva da Universidade Federal de São Paulo, 1995 out 6: São Paulo, Brasil]

Tellis $\mathrm{W}$. Introdution to case study. The qualitative report [periódico on line] $1997 \mathrm{a}$; 3(2). available from http://www.nova.edu/ssss/QR/QR3-2/tellisl.html) [11/10/00].

Tellis $\mathrm{W}$. The case study as a research method. use and users of information [periódico on line] 1997b; available from http://www.gslis. utexas.edu/ ssoy/useusers/139ldlb.htm ) [11/10/00].

Tomaz JB. O desenho do currículo. In: Mamede S e Penaforte J. (org.), Aprendizagem baseada em problemas. $1^{a}$ ed.São Paulo. Hucitec, 2001. p. 109-139. 
Triviños ANS. Introdução à pesquisa em ciências sociais. São Paulo: Atlas, 1987

University of New Mexico. Health Science Center. Albuquerque; s/d. (a)

University of New Mexico. Office of the president. Albuquerque; s/d. (b)

University of New Mexico: School of Medicine. Primary care curriculum $\&$ health of the public program. Albuquerque; 1989.

University of New Mexico: School of Medicine. Curriculum committee retreat May 29-30, 1991. Albuquerque; 1991.

University of New Mexico: School of Medicine. Community-Oriented problembased-learning at the University of New Mexico. Albuquerque; 1992.

University of New Mexico: Teacher \& Education Development. Phase I tutorial update. Albuquerque; 1996.

University of New Mexico: Health Science Center. Healthcare for today, research and education for tomorrow. Albuquerque; 1998a.

University of New Mexico: School of Medicine. Graduate medical education. Albuquerque; 1998b.

University of New Mexico: Health Sciences Center. School of Medicine. Albuquerque; 1998c.

University of New Mexico: School of Medicine. Student progress assessment. Albuquerque; $1998 \mathrm{~d}$.

University of New Mexico: Tutorial overview phases one and two: steering committee. Albuquerque; 1998e.

University of New Mexico: School of Medicine. Assessment report. Albuquerque; 1999a.

University of New Mexico: Tutor training \& case development workshop: problem based learning, 1999b oct 5-7; Albuquerque, USA.Albuquerque; 1999b

University of New Mexico: School of Medicine. Student progress assessment: orientation handbook. Albuquerque; 2000.

University of New Mexico: School of Medicine. Instructors handbook: Phase I; 2000-2001. Albuquerque; 2001.

Venturelli J. Educación médica: nuevos enfoques, metas y métodos. Washington: OMS/OPAS; 1997. 
Walton HJ, Mattews MB. Essentials of problem-based learning Med Educ 1989; 23: 54258 .

Westphal MF. Participação popular e políticas municipais de saúde: Cotia e Vargem Grande Paulista. São Paulo; 1992. [Tese de Livre Docência - Faculdade de Saúde Pública da USP]. 
Anexos 


\section{ANEXO 1 - Roteiro de observação}

\section{Escola de Medicina da Universidade do Novo México}

- Métodos e recursos de ensino aprendizagem

- Organização da atividade grupal (início, discussão e andamento)

- Dinâmica de grupo, cooperação, respeito, comunicação e interesse

- Relação aluno-tutor

- Avaliação do tutorial 


\section{ANEXO 2 - INVITATION AND CONSENT TO PARTICIPATE IN RESEARCH (student/faculty/tutor)}

You are invited to participate in a research study conducted by Regina Helena P. Pontes, doctoral candidate, from the School of Public Health, University of Sao Paulo, Brazil. The results of this study will contribute to a doctoral dissertation. You have been selected as a possible participant in this study because you are a medical student/faculty/tutor.

\section{PURPOSE OF THE STUDY}

The purpose of this study is to develop an in-depth understanding of the daily activities and workings of The University of New Mexico School of Medicine curriculum in order to plan and implement a similar curriculum at my own School of Medicine, the Federal University of Sao Paulo, Brazil. Specific topics of research inquiry include the educational philosophy, pedagogic approaches, educational skills such as tutoring, choice of cases and other educational materials, and the history and evolution of the curriculum. In addition, an important focus of this research is to document and describe the relationship between the objectives of UNM's School of Medicine education programs and the health policies and needs of New Mexicans.

\section{PROCEDURES INVOLVED IN PARTICIPATING IN THE STUDY}

If you agree to participate in this study, all data collection will be complete within a 1 to 2 month period. You will be asked to do the following:

1. Sign a consent form

2. Complete a survey

3. Possibly participate in two separate, one-hour personal interviews. The interviews will be audiotaped and take place at a time and iocation convenient for you. 


\section{CONFIDENTIALITY}

Your identity will be kept anonymous and in the strictest confidence. It will not be linked to the data collected. Confidentiality will be maintained by using pseudo names and generalities for any identifying characteristics such as a specific discipline or department.

However, with your permission, your remarks in this study may be identified with you by name and printed in my official dissertation.

Please mark the appropriate box:

I agree to disclose my identity and to have all comments linked to me by name.

I do not want my identity linked to any comments I disclose. I wish my identity to remain anonymous throughout this study

\section{PARTICIPATION AND WITHDRAWAL}

Your participation is VOLUNTARY. If you decide to participate, you are free to withdrawal your consent and discontinue participation at any time without penalty. The investigator may withdrawal you from this research if circumstances arise which warrant doing so.

\section{IDENTIFICATION OF INVESTIGATORS}

If you have any questions or concerns about your participation in the research, please feel free to contact Regina H. P. Pontes at 272 4173, Masters of Public Health Program, Family Practice Center, University of New Mexico. 


\section{RIGHTS OF RESEARCH SUBJECTS}

You may withdrawal your consent at anytime and discontinue participation without penalty. You are not waiving any legal claims, rights or remedies because of your participation in this research study.

\section{SIGNATURE OF RESEARCH PARTICIPANT}

My signature indicates that I have read and understand the information provided above, and that I willingly agree to participate in this research study.

SIGNATURE OF RESEARCH PARTICIPANT

DATE

SIGNATURE OF INVESTIGATOR

SIGNATURE OF INVESTIGATOR

DATE 


\section{ANEXO 3 - Interview UNM}

\section{General}

What department are you from?

How long have you been a coordinator?

1. Did you tutor in Primary Care Curriculum?

If yes, tell me about CCPS (Currículo de Cuidados primários em Saúde)

\section{Curriculum reform}

In 1991, UNM introduced the current curriculum in the HSC School of Medicine.

2. Describe the differences between the current curriculum and the curriculum that existed prior to 1991 ?

(What changed following the introduction of the new curriculum?)

3. What were the objectives of this curriculum change?

\section{Medical Education}

4. The goal of medical education is to train physicians to meet the basic health care needs of the population. How does the UNM medical school address this goal?

5. Another broader goal is to train physicians to assess and address community health needs and improve health status, such as safe environments, availability of clean water and nutritional foods, domestic violence reduction, substance abuse prevention education, transportation needs etc. How does the UNM medical school address this goal?

6. How does the introduction of PBL in the curriculum specifically help prepare students to

- Meet the clinical health care needs of the population?

- Improve or influence the health status of NM communities?

7. Comparing the abilities and characteristics of UNM medical school graduates before, and after, the curriculum change, in what ways were graduates: 
- More or less prepared to meet the clinical health care needs of NM's population after the change?

- More or less prepared to impact the health status of NM communities?

8. What types of physicians (i.e. generalist vs. specialists) are needed to meet the

- Clinical health care needs of people in NM?

- health needs of communities in NM?

\section{NM Health needs}

9. What are the top 3 or 4 health care needs of the NM population?

10. What are the top 3 or 4 community health needs of the NM population?

\section{Case development}

The medical School program was designed to prepare physicians to address the health needs of New Mexicans. New Mexico is the $5^{\text {th }}$ largest state, with a large percentage of its population distributed in rural locations. Many areas suffer from limited access to primary health care. In the 1980's, a primary goal of the UNM Medical School was to prepare physicians to address the unmet health care needs of rural New Mexicans.

1. Has this goal changed?

1. What were/are the obstacles to addressing this goal?

2. Have the curriculum changes made it more difficult or more simple to address this goal? How?

3. Who select topics for cases presented in tutorials?

4. What are the criteria used for selecting and describing cases?

5. How do the cases prepare medical students to work effectively as physician in New Mexico?

6. In general, the medical education program instructs students in biological factors associated with health. How does the program instruct students in another areas of equal importance?

7. Are tutors prepared to discuss these factors?

8. How do the tutorials and case studies teach students social sciences, epidemiology, economics, demographics, public health, and the importance of these disciplines to understanding human health? 


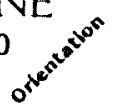

EAR 1
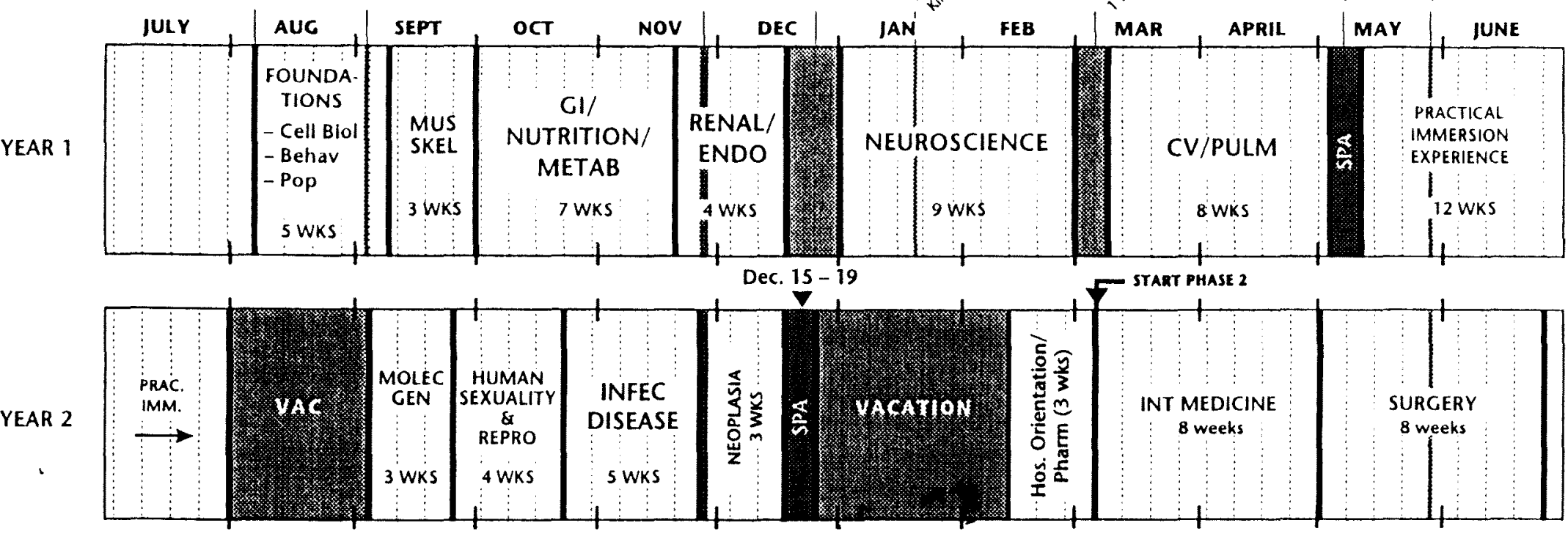

YEAR 3

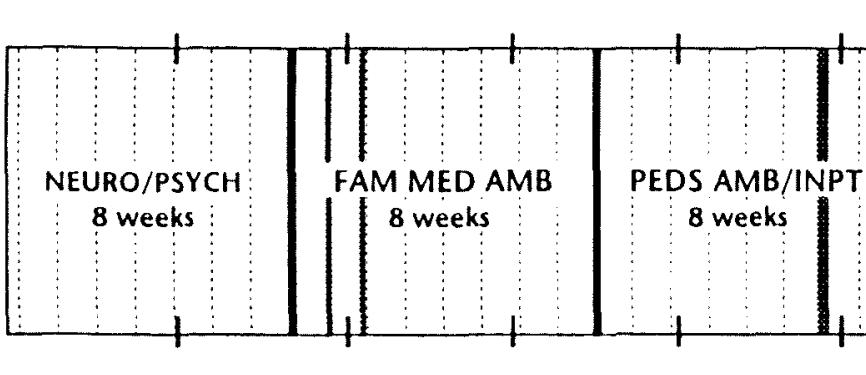

- Start phase 3






\section{Example of a Possible Week's Activities - Phase II}






\section{University of New Mexico Health Sciences Center Patient Care and Education Sites}

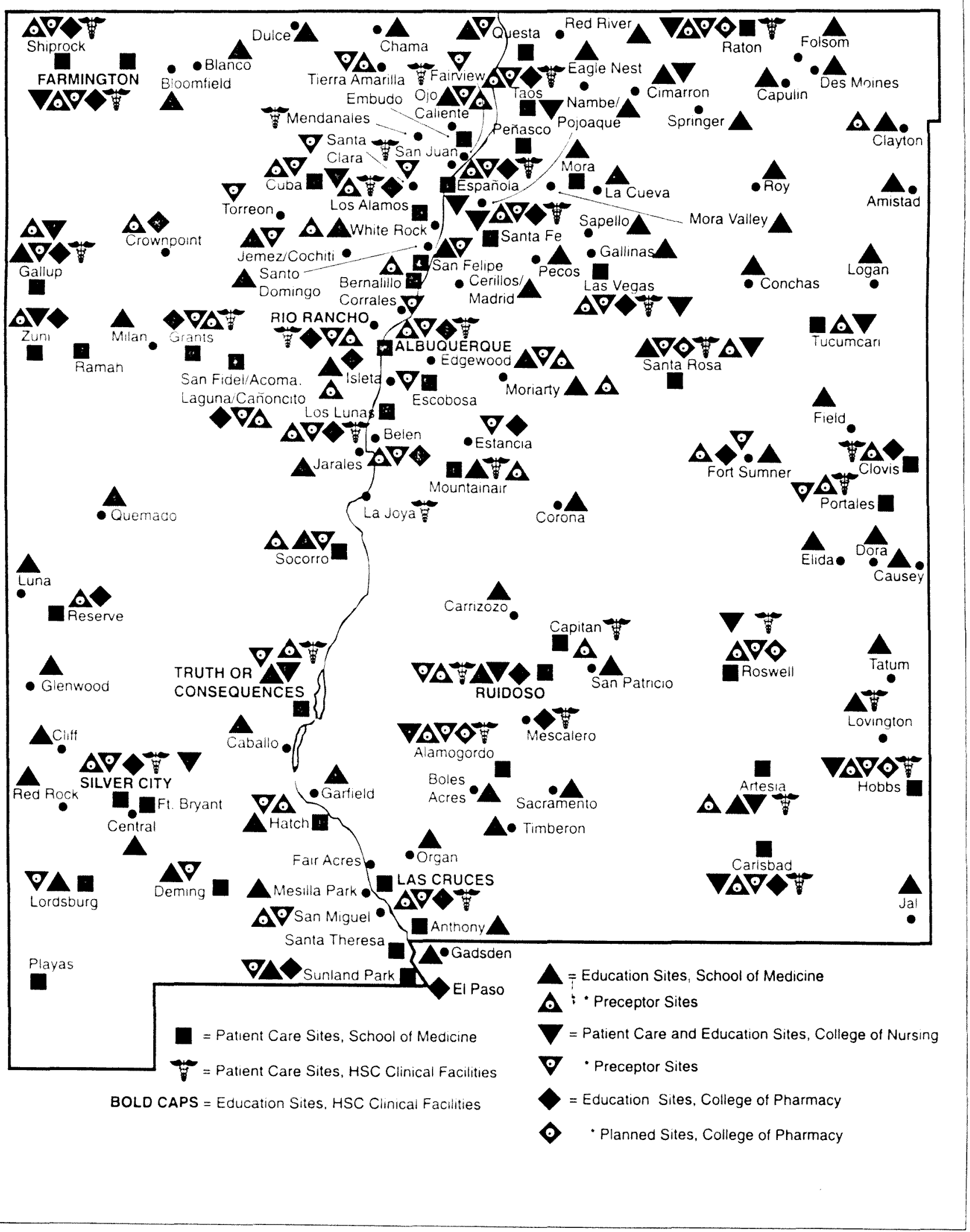




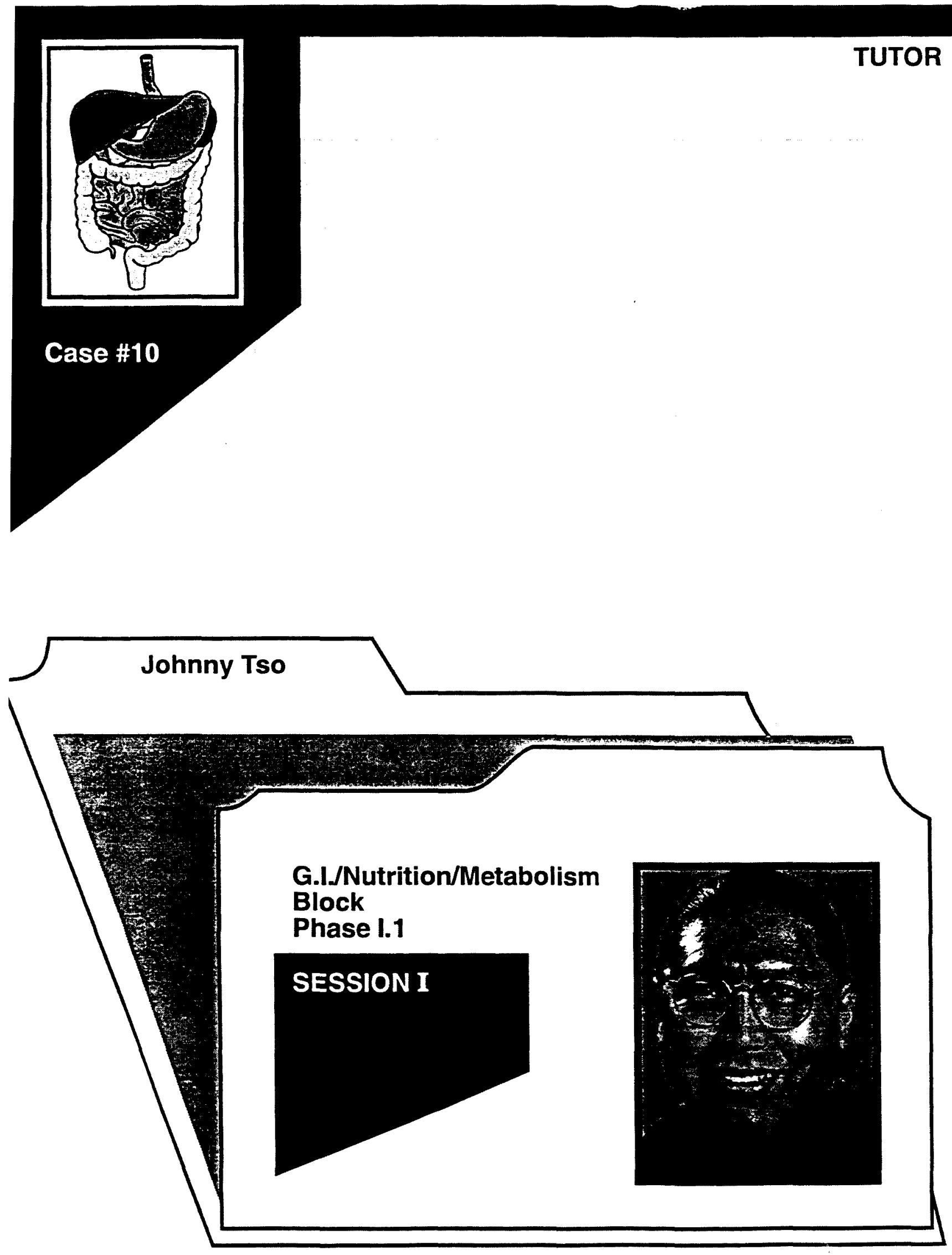

UNIVERSITY OF NEW MEXICO SCHOOL OF MEDICINE 


\section{CASE AUTHORS}

Denis McCarthy. M.D.

William Galey, Ph.D.

Phillip Reyes, Ph.D.

D.L. VanderJagt. Ph.D.

Beulah Woodfin. Ph.D.

William Black, M.D.

William Dail, Ph.D.

\section{CASE DEsigners}

Biomedical Communications

School of Medicine

University of New Mexico

Albuquerque, New Mexico

Copyright $\odot 1995$, by School of Medicine, University of New Mexico, Albuquerque, New Mexico. All rights reserved. No part of this material may be used or reproduced in any manner whatsoever without written permission of the authors. 


\title{
CASE \#10 -- Johnny Tso

\author{
PERNICIOUS ANEMIA
}

\author{
TUTOR COPY
}

\section{SESSION I}

\section{OVERVIEW}

This is a case of pernicious anemia. It should focus on the absorption and function of Vitamin $B_{12}$, folic acid, and other water-soluble vitamins. The consequences of $\mathrm{B}_{12}$ deficiency should be studied, including effects on red blood cell production and neurological function.

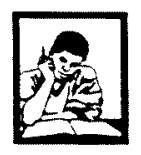

\section{EXPECTED LEARNING ISSUES}

1) Mechanisms of Vitamin $B_{12}$ absorption

2) Biochemistry of Vitamin $B_{12}$ and consequences of $B_{12}$ deficiency

3) Immunology of pernicious anemia

4) Schilling test

5) Dangers of stereotyping 


\section{CASE \#10 -- Johnny Tso}

\section{TUTOR COPY}

\section{SESSION I}

\section{PATIENT PRESENTATION}

Johnny Tso, a graduate of Harvard Law School, is a 32-year-old, Navajo attorney. For the past year, his appetite has been poor and his weight has decreased six pounds. He has had no energy, and he has noticed that he is always pale. Sometimes he belches foul smelling gas. For the past six weeks, the tips of his fingers and toes have seemed a bit numb and "tingling." He has stumbled occasionally, especially in the dark. He feels he is "going downhill." He worries that he has cancer because his maternal aunt died of some type of gastric cancer at age 50. He does not smoke or drink.

\section{$\pi$}

\section{DISCUSSION QUESTIONS}

1) What are Mr. Tso's problems?

2) What are your hypotheses? Explain your reasoning.

3) What are the mechanisms for your top hypotheses?

4) What further historical information do you need? Explain your rationale. 
2) Can you list your hypotheses for the mechanisms leading to the patient's problems?

Hypotheses List:

1) poor appetite
A) metabolic disorder
B) CNS disorder (appetite center)
C) behavioral disorders (depression)
D) secondary to other diseases

2) foul smelling belches (eructation)
A) swallowed air
B) bacterial growth in upper G.I. tract
1) hypochlorhydria
2) gastrocolic fistula

3) lack of energy

A) metabolic compromise
1) caloric deficiency
2) vitamin/mineral deficiency
3) hypothyroidism

B) impaired oxygen delivery

1) anemia

2) decreased oxygen transport from lungs

C) psychological

\section{Prompting Questions}

A) What are some causes of poor appetite?

B) What can cause foul smelling gas to form in the stomach?

C) What are possible causes of the patient's lack of energy? 
Hypotheses List -- continued:

4) tingling of toes and fingers
A) vascular insufficiency
B) metabolism

1) vitamin deficiency $\left(B_{12}\right)$

2) vitamin deficiency $\left(B_{6}\right)$

C) inflammation of tissues

D) trauma
1) mechanical
2) chemical

Prompting Questions -- continued

D) What can cause the tingling in the patient's fingers and toes? 


\section{PATIENT HISTORY}

\section{History of Present IIIness (HPI)}

Mr. Tso noticed the initial symptoms about a year ago. The more serious symptoms appeared six weeks ago. Mr. Tso tells you he "can't afford to miss work." He says he is now at a point where he feels he "has no other choice but to seek treatment."

\section{[ Past Medical History}

Before the symptoms appeared, Mr. Tso had been typically healthy.

\section{Risk Factor Assessment}

\section{fixed factors}

- family history - Mr. Tso has a family history of G.I. cancer. The patient's maternal aunt died from G.l. cancer.

\section{acquired factors}

- environmental - There are no environmental factors that contribute to the case.

- behavioral -

> alcohol: Mr. Tso does not drink.

$>$ tobacco: He does not smoke.

$>$ caffeine: He drinks 2 cups of coffee per day.

$>$ illegal drugs: He does not use illegal drugs.

$>$ sexual: He has a monogamous sexual relationship with his wife.

$>$ exercise: He used to jog regularly.

$>$ dietary habits: Mr. Tso's appetite has been poor for the past year.

- health maintenance - Mr. Tso rarely sees his physician. His immunizations are up-to-date.

- disease associated - non-contributory

- treatment associated -

$>$ surgery: none

$>$ allergies: none

$>$ medications: Mr. Tso is currently not taking any medication. 


\section{Social History}

Mr. Tso lives in Albuquerque with his wife and two small children. His wife is a homemaker. Mr. Tso has full financial responsibility for the family. Also, he helps some family members financially, who live in Crown Point, New Mexico. All these obligations have kept him from seeking help earlier.

\section{DISCUSSION QUESTIONS}

1) How does this information influenced your hypotheses?

2) What physical exam information do you need? Explain your rationale. 


\section{PHYSICAL EXAM}

- height $=5{ }^{\prime} 10^{\prime \prime}$

- temperature $=37^{\circ} \mathrm{C}$

- respiration $=24 / \mathrm{min}$.
- weight $=146 \mathrm{lbs}$.

- pulse = 96/min.

- blood pressure $=128 / 80$

- appearance: unremarkable

- head, eyes, ears, nose, throat (HEENT): He has a pale, smooth tongue.

- skin: Mr. Tso has pale skin and mucous membranes.

- neck: unremarkable

- chest: unremarkable

- cardiac: unremarkable

- abdomen: unremarkable

- extremities: The rest of the physical examination is normal except for the extremities. He has trouble with balance and difficulty knowing the position of his fingers and toes when his eyes are closed. He has a loss of vibrational sense at the ankles and wrists.

\section{(1)}

\section{DISCUSSION QUESTIONS}

1) How has the physical examination helped you? Do you want to change your rank order of hypotheses based on the physical exam? If so, explain.

2) What lab tests and/or investigations you would like to do now to test your hypotheses? What are your reasons for ordering the lab tests or investigations? How would you explain to $\mathrm{Mr}$. Tso why these are necessary? 


\section{(1) Lab Tests:}

1) complete blood count with differential (CBC w/diff.)

This test helps in the diagnosis of anemia.

2) serum iron

This test measures the amount of iron bound to transferrin.

3) total iron binding capacity (TIBC)

TIBC is the iron content of plasma when transferrin is saturated with iron.

\section{4) percentage of saturation}

This value is obtained by dividing serum iron by TIBC.

Note to Tutor: Tests 1-4 above, as a group, are used to evaluate iron status and are useful in distinguishing between iron-deficiency anemia and anemia due to other causes.

However, it should be understood that iron metabolism is not meant to be a major learning issue in this case.

\section{5) serum folate}

This test helps to assess the contribution of folate deficiency to anemia.

6) serum vitamin $B_{12}$

This test helps to assess the contribution of vitamin B12 deficiency to anemia. It is also useful in the differential diagnosis of CNS disorders involving myelinated nerves.

\section{7) $\mathrm{TSH}$}

This test helps in the diagnosis of hypothyroidism. Also, it helps in the differential diagnosis of hypothyroidism resulting from thyroid gland dysfunction from pituitary or hypothalamic dysfunction.

8) serum glucose

This test helps identify disorders of glucose metabolism.

9) blood gases ( $\mathrm{pH}, \mathrm{pCO}_{2} \mathrm{O}_{2}$, Sat., $\left.\mathrm{HCO}_{3}^{-}\right)$

These tests evaluate acid-base status. 
(11) Lab Tests - continued:

10) serum electrolytes

This test helps to assess fluid, electrolyte and acid-base imbalances.

11) anti-intrinsic factor antibodies

These antibodies are found in the serum of patients with pernicious anemia and other anti-immune disorders.

12) serum homocysteine

This test measures abnormal metabolism in folate or vitamin $\mathrm{B}_{12}$ deficiency.

13) serum methylmalonic acid

This test measures abnormal metabolism in vitamin $B_{12}$ deficiency.

14) serum creatinine

This test of renal function helps to interpret homocysteine and methylmalonic acid results.

\section{目 Investigations:}

\section{1) Schilling test}

The first part of this test assesses vitamin $B_{12}$ absorption from the bowel by measuring urinary excretion of the vitamin following standard doses of radioactive and nonradioactive vitamin $\mathrm{B}_{12}$.

The test distinguishes between intrinsic factor deficiency and malabsorption syndromes. The second part of the test is used to confirm a deficiency of intrinsic factor.

Note to Tutor: Review the learning issues with the students before they leave Session I. Make sure that these are consistent with the Expected Learning Issues at the beginning of this case. 


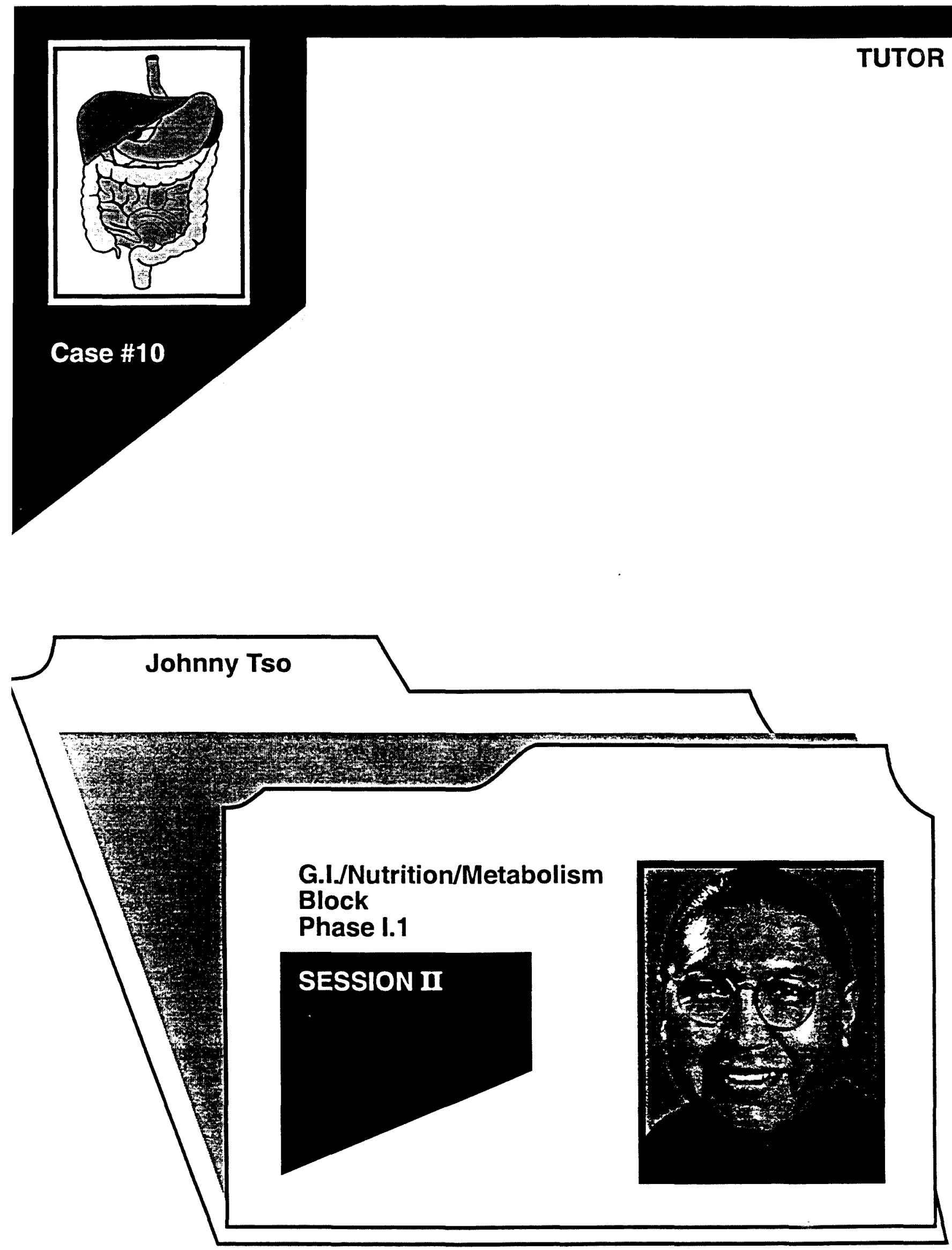




\section{CASE \#10 -- Johnny Tso}

\section{PERNICIOUS ANEMIA}

\section{TUTOR COPY}

\section{SESSION II}

\section{OVERVIEW}

In this session, the students will discuss the learning issues identified in Session I. Discussions should take into account the results of the lab tests and investigations. Also, they should consider the issues of patient treatment and support.

\section{EXPECTED LEARNING ISSUES}

1) Mechanisms of Vitamin $B_{12}$ absorption

2) Biochemistry of Vitamin $B_{12}$ and consequences of $B_{12}$ deficiency

3) Immunology of pernicious anemia

4) Schilling test

5) Dangers of stereotyping 


\section{CASE \#10 -- Johnny Tso}

\section{TUTOR COPY}

\section{SESSION II}

\section{LABORATORY TESTS/INVESTIGATIONS - RESULTS}

The lab tests and investigations you decided to perform are as follows:
10 Lab Tests:
results
normal values

1) complete blood count with differential $(\mathrm{CBC}$ w/diff. $)($ cost $=\$ 22.50)$
HCT
HGB
MCV
$\mathrm{MCH}$
$\mathrm{MCHC}$
WBC
SEGS

\section{bands \\ lymphs \\ monos \\ platelets}

2) serum iron $(\operatorname{cost}=\$ 20.00)$

3) total iron binding capacity

$($ TIBC) $(\operatorname{cost}=\$ 9.50)$

4) percentage of saturation $(\operatorname{cost}=\$ 9.50)$

5) serum folate $(\operatorname{cost}=\$ 47.75)$

6) serum vitamin $B_{12}$ $(\cos t=\$ 47.75)$

7) $\mathrm{TSH}(\operatorname{cost}=\$ 13.50)$

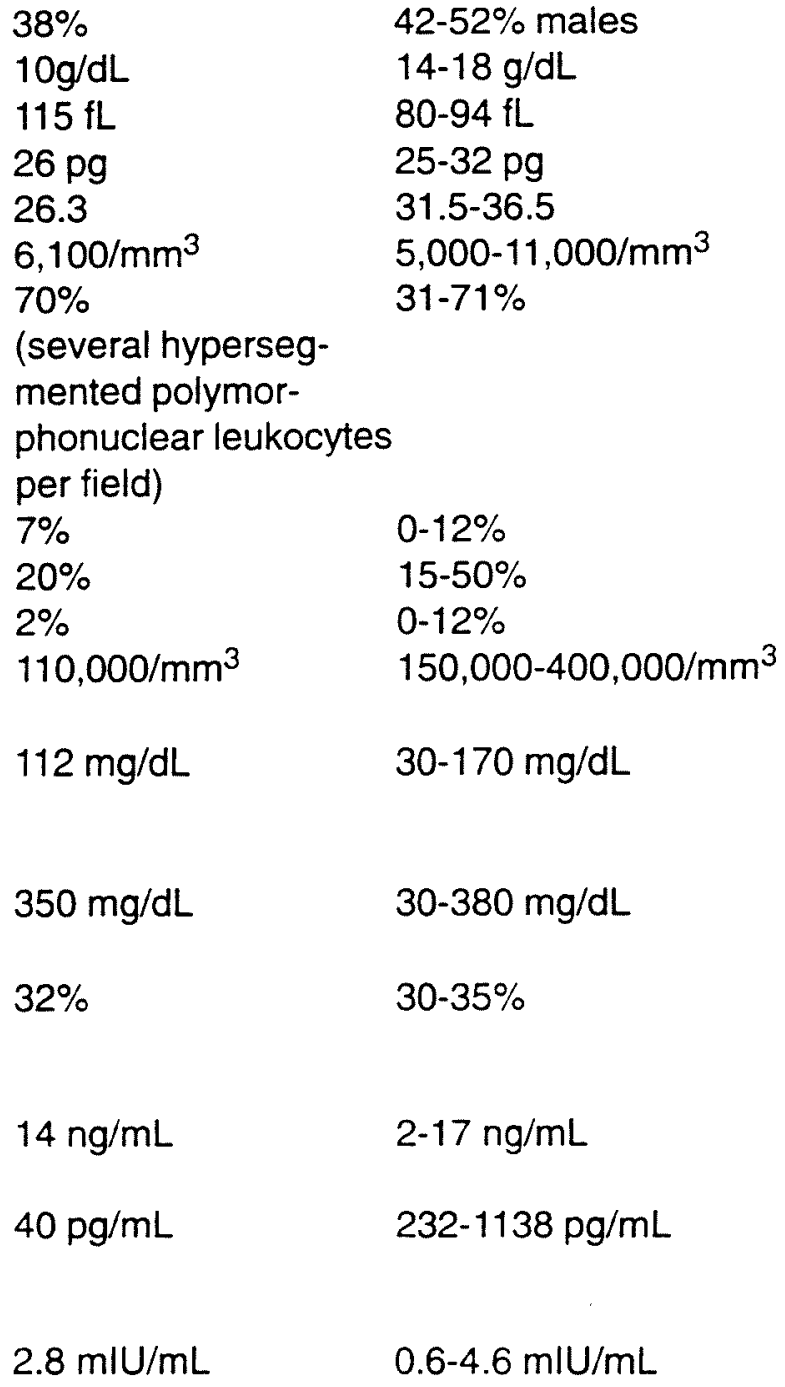

$112 \mathrm{mg} / \mathrm{dL}$

$30-170 \mathrm{mg} / \mathrm{dL}$

$350 \mathrm{mg} / \mathrm{dL}$

$30-380 \mathrm{mg} / \mathrm{dL}$

$32 \%$

$30-35 \%$

$14 \mathrm{ng} / \mathrm{mL}$

$2-17 \mathrm{ng} / \mathrm{mL}$

$40 \mathrm{pg} / \mathrm{mL}$

$232-1138 \mathrm{pg} / \mathrm{mL}$

$2.8 \mathrm{mIU} / \mathrm{mL}$

$0.6-4.6 \mathrm{mIU} / \mathrm{mL}$ 
11 Lab Tests - continued:

8) serum glucose $(\operatorname{cost}=\$ 9.50)$

9) blood gases $(\operatorname{cost}=\$ 47.75)$

10) serum electrolytes $(\operatorname{cost}=\$ 9.50)$

11) anti-intrinsic factor antibodies $(\cos t=\$ 32.00)$

12) serum homocysteine

$($ cost $=\$ 35.00)$

13) serum methylmalonic acid $(\cos t=\$ 35.00)$

14) serum creatinine $($ cost $=\$ 9.50)$

首 Investigations:

Part I-Schilling test $(\operatorname{cost}=\$ 50.00)$

Part II-Schilling test (+IF) results

normal values

$80 \mathrm{mg} / \mathrm{dL}$

$70-105 \mathrm{mg} / \mathrm{dL}$

normal

normal

positive 1:640

negative

$27 \mu \mathrm{mol} / \mathrm{L}$

$<21 \mu \mathrm{mol} / \mathrm{L}$

$678 \mathrm{nmol} / \mathrm{L}$

$<376 \mathrm{nmol} / \mathrm{L}$

$0.95 \mathrm{mg} / \mathrm{dL}$

$0.6-1.2 \mathrm{mg} / \mathrm{dL}$

results

normal values

less than $1 \%$

excreted in 24 hours

$>10 \%$ excreted

$21 \%$

$>10 \%$ excreted

excreted in 24 hours 


\section{DISCUSSION QUESTIONS}

1) How would you interpret these test results? Would you rerank your hypotheses based on the results you now have as to what you think is wrong with Mr. Tso?

2) How would you explain Mr. Tso's problems to him? How would you discuss your treatment plan with him? How would you discuss the impact of his illness on his life-style? Would this discussion be different if he were an elderly Navajo from the reservation? What issues of stereotyping can you explore?

3) Do you have additional learning issues or need to clarify current issues? Make sure you study them for the next tutorial. 


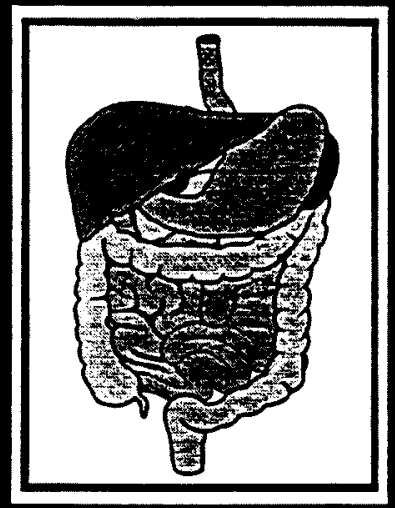

\section{Case \#10}






\section{CASE AUTEORS}

Denis McCarthy, M.D.

William Galey, Ph.D.

Phillip Reyes, Ph.D.

D.L. VanderJagt, Ph.D.

Beulah Woodfin. Ph.D.

William Black. M.D.

William Dail, Ph.D.

\section{CASE DESIGNERS}

Biomedical Communications

School of Medicine

University of New Mexico

Albuquerque, New Mexico

Copyright ( 1 1995, by School of Medicine, University of New Mexico, Albuquerque, New Mexico. All rights reserved. No part of this material may be used or reproduced in any manner whatsoever without written permission of the authors. 
CASE \#10 -- Johnny Tso

\section{STUDENT COPY}

\section{SESSION I}

\section{PATIENT PRESENTATION}

Johnny Tso, a graduate of Harvard Law School, is a 32-year-old Navaio attorney. For the past year, his appetite has been poor and his weight has decreased six pounds. He has had no energy, and he has noticed that he is always pale. Sometimes he belches foul smelling gas. For the past six weeks, the tips of his fingers and toes have seemed a bit numb and "tingling." He has stumbled occasionally, especially in the dark. He feels he is "going downhill." He worries that he has cancer because his maternal aunt died of some type of gastric cancer at age 50 . He does not smoke or drink.

\section{DISCUSSION QUESTIONS}

1) What are Mr. Tso's problems?

2) What are your hypotheses? Explain your reasoning.

3) What are the mechanisms for your top hypotheses?

4) What further historical information do you need? Explain your rationale. 


\section{PATIENT HISTORY}

History of Present IIIness (HPI)

Mr. Tso noticed the initial symptoms about a year ago. The more serious symptoms appeared six weeks ago. Mr. Tso tells you he "can't afford to miss work." He says he is now at a point where he feels he "has no other choice but to seek treatment."

\section{[ Past Medical History}

Before the symptoms appeared, Mr. Tso had been typically healthy.

\section{$¥$ Risk Factor Assessment}

\section{fixed factors}

- family history - Mr. Tso has a family history of G.I. cancer. The patient's maternal aunt died from G.I. cancer.

\section{acquired factors}

- environmental - There are no environmental factors that contribute to the case.

- behavioral -

$>$ alcohol: Mr. Tso does not drink.

$>$ tobacco: He does not smoke.

$>$ caffeine: He drinks 2 cups of coffee per day.

$>$ illegal drugs: He does not use illegal drugs.

$>$ sexual: He has a monogamous sexual relationship with his wife.

$>$ exercise: He used to jog regularly.

$>$ dietary habits: Mr. Tso's appetite has been poor for the past year.

- health maintenance - Mr. Tso rarely sees his physician. His immunizations are up-to-date.

- disease associated - non-contributory

- treatment associated -

$>$ surgery: none

$>$ allergies: none

$>$ medications: Mr. Tso is currently not taking any medication. 


\section{Social History}

Mr. Tso lives in Albuquerque with his wife and two small children. His wife is a homemaker. Mr. Tso has full financial responsibility for the family. Also, he helps some family members financially, who live in Crown Point, New Mexico. All these obligations have kept him from seeking help earlier.

\section{DISCUSSION QUESTIONS}

1) How does this information influenced your hypotheses?

2) What physical exam information do you need? Explain your rationale. 


\section{PHYSICAL EXAM}

- height $=5^{\prime} 10^{\prime \prime}$

- temperature $=37^{\circ} \mathrm{C}$

- respiration $=24 / \mathrm{min}$.
- weight $=146 \mathrm{lbs}$.

- pulse $=96 / \mathrm{min}$.

- blood pressure $=128 / 80$

- appearance: unremarkable

- head, eyes, ears, nose, throat (HEENT): He has a pale, smooth tongue.

- skin: Mr. Tso has pale skin and mucous membranes.

- neck: unremarkable

- chest: unremarkable

- cardiac: unremarkable

- abdomen: unremarkable

- extremities: The rest of the physical examination is normal except for the extremities. He has trouble with balance and difficulty knowing the position of his fingers and toes when his eyes are closed. He has a loss of vibrational sense at the ankles and wrists.

\section{DISCUSSION QUESTIONS}

1) How has the physical examination helped you? Do you want to change your rank order of hypotheses based on the physical exam? If so, explain.

2) What lab tests and/or investigations you would like to do now to test your hypotheses? What are your reasons for ordering the lab tests or investigations? How would you explain to Mr. Tso why these are necessary? 


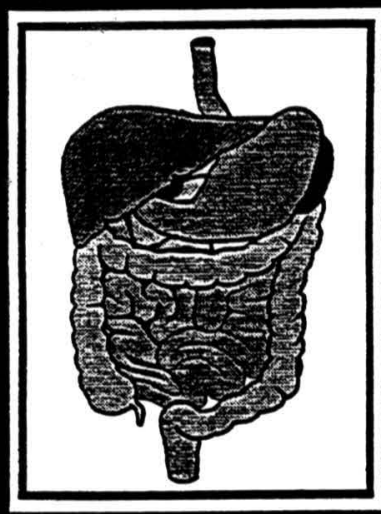

STUDENT

Case \#10

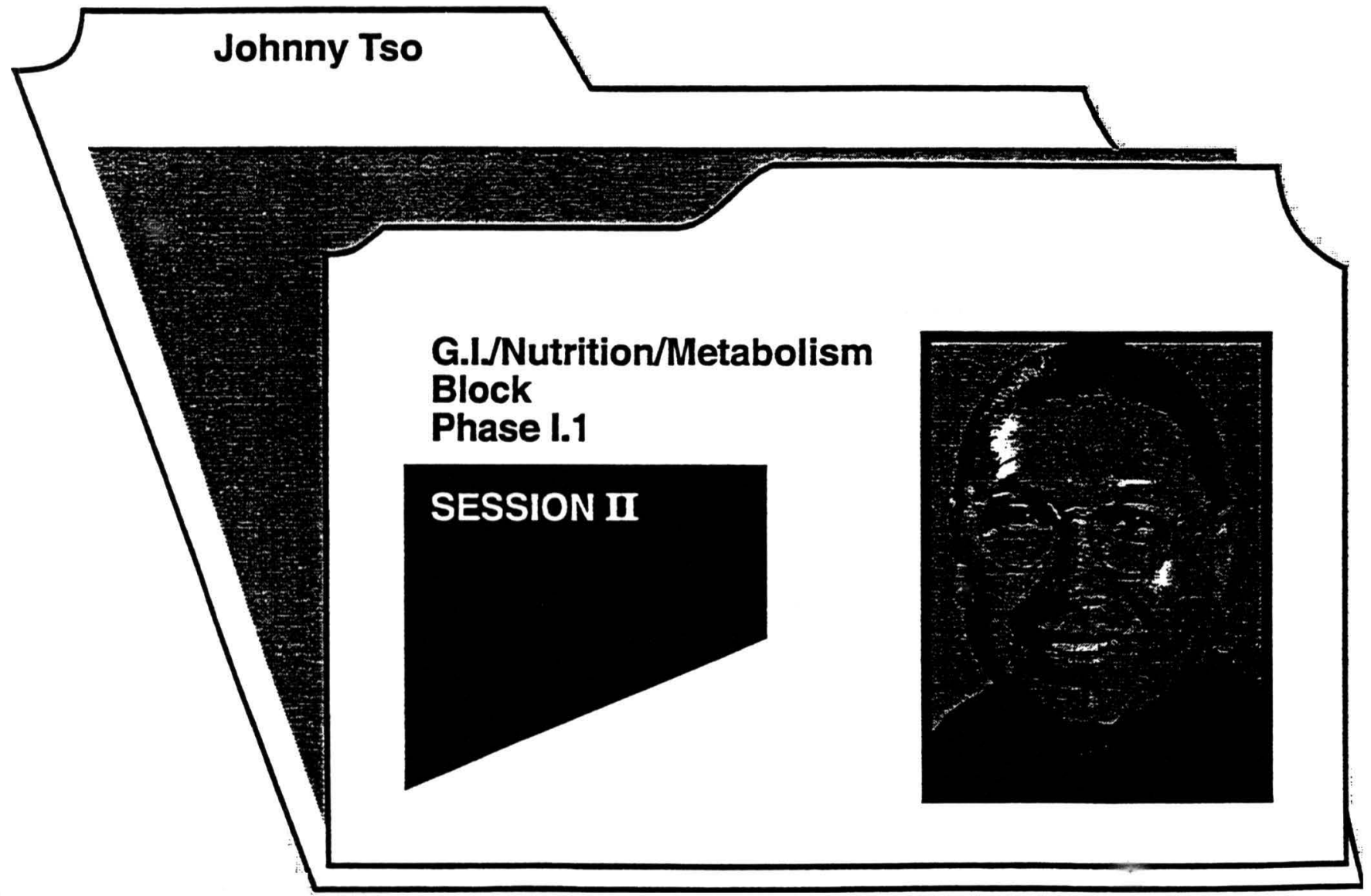

UNIVERSITY OF NEW MEXICO SCHOOL OF MEDICINE 


\section{CASE \#10 - Johnny Tso \\ STUDENT COPY}

\section{SESSION II}

\section{LABORATORY TESTS/NVESTIGATIONS - RESULTS}

The lab tests and investigations you decided to perform are as follows:

1] Lab Tests:

results

normal values

1) complete blood count with differential

$(C B C$ w/diff.) $(\operatorname{cost}=\$ 22.50)$

\begin{tabular}{|c|c|c|}
\hline $\begin{array}{l}\text { HCT } \\
\text { HGB } \\
\text { MCV } \\
\text { MCH } \\
\text { MCHC } \\
\text { WBC } \\
\text { SEGS }\end{array}$ & $\begin{array}{l}38 \% \\
10 \mathrm{~g} / \mathrm{dL} \\
115 \mathrm{fL} \\
26 \mathrm{pg} \\
26.3 \\
6,100 / \mathrm{mm}^{3} \\
70 \% \\
\text { (several hyperseg- } \\
\text { mented polymor- } \\
\text { phonuclear leukocytes } \\
\text { per field) }\end{array}$ & $\begin{array}{l}42-52 \% \text { males } \\
14-18 \mathrm{~g} / \mathrm{dL} \\
80-94 \mathrm{fL} \\
25-32 \mathrm{pg} \\
31.5-36.5 \\
5,000-11,000 / \mathrm{mm}^{3} \\
31-71 \% \\
\text { s }\end{array}$ \\
\hline bands & $7 \%$ & $0-12 \%$ \\
\hline lymphs & $20 \%$ & $15-50 \%$ \\
\hline monos & $2 \%$ & $0-12 \%$ \\
\hline platelets & $110,000 / \mathrm{mm}^{3}$ & $150,000-400,000 / \mathrm{mm}^{3}$ \\
\hline rum iron (cost $=\$ 20.00)$ & $112 \mathrm{mg} / \mathrm{dL}$ & $30-170 \mathrm{mg} / \mathrm{dL}$ \\
\hline $\begin{array}{l}\text { tal iron binding capacity } \\
\mathrm{IBC})(\text { cost }=\$ 9.50)\end{array}$ & $350 \mathrm{mg} / \mathrm{dL}$ & $30-380 \mathrm{mg} / \mathrm{dL}$ \\
\hline $\begin{array}{l}\text { ercentage of saturation } \\
\text { ost }=\$ 9.50)\end{array}$ & $32 \%$ & $30-35 \%$ \\
\hline rum folate (cost $=\$ 47.75)$ & $14 \mathrm{ng} / \mathrm{mL}$ & $2-17 \mathrm{ng} / \mathrm{mL}$ \\
\hline $\begin{array}{l}\text { rum vitamin } B_{12} \\
\text { ost }=\$ 47.75)\end{array}$ & $40 \mathrm{pg} / \mathrm{mL}$ & $232-1138 \mathrm{pg} / \mathrm{mL}$ \\
\hline $\mathrm{H}(\operatorname{cost}=\$ 13.50)$ & $2.8 \mathrm{mIU} / \mathrm{mL}$ & $0.6-4.6 \mathrm{mlU} / \mathrm{mL}$ \\
\hline
\end{tabular}


(1) Lab Tests - continued:

8) serum glucose (cost $=\$ 9.50)$

9) blood gases $($ cost $=\$ 47.75)$

10) serum electrolytes $(\operatorname{cost}=\$ 9.50)$

11) anti-intrinsic factor antibodies (cost $=\$ 32.00)$

12) serum homocysteine $($ cost $=\$ 35.00)$

13) serum methylmalonic acid (cost $=\$ 35.00)$

14) serum creatinine $(\operatorname{cost}=\$ 9.50)$

䀚 Investigations:

Part I-Schilling test $(\operatorname{cost}=\$ 50.00)$

Part II-Schilling test (+IF) results

normal values

$80 \mathrm{mg} / \mathrm{dL}$

$70-105 \mathrm{mg} / \mathrm{dL}$

normal

normal

positive 1:640

negative

$27 \mu \mathrm{mol} / \mathrm{L}$

$<21 \mu \mathrm{mol} / \mathrm{L}$

$678 \mathrm{nmol} / \mathrm{L}$

$<376 \mathrm{nmoll}$

$0.95 \mathrm{mg} / \mathrm{dL}$

$0.6-1.2 \mathrm{mg} / \mathrm{dL}$

results

normal values

less than $1 \%$

excreted in 24 hours

$21 \%$

excreted in 24 hours
$>10 \%$ excreted $>10 \%$ excreted 


\section{DISCUSSION QUESTIONS}

1) How would you interpret these test results? Would you rerank your hypotheses based on the results you now have as to what you think is wrong with Mr. Tso?

2) How would you explain Mr. Tso's problems to him? How would you discuss your treatment plan with him? How would you discuss the impact of his illness on his life-style? Would this discussion be different if he were an elderly Navajo from the reservation? What issues of stereotyping can you explore?

3) Do you have additional learning issues or need to clarify current issues? Make sure you study them for the next tutorial. 


\section{PATIENT HISTORY}

$\square$ History of Present IIIness (HPI)

Mr. Tso noticed the initial symptoms about a year ago. The more serious symptoms appeared six weeks ago. Mr. Tso tells you he "can't afford to miss work." He says he is now at a point where he feels he "has no other choice but to seek treatment."

\section{$[$ Past Medical History}

Before the symptoms appeared, Mr. Tso had been typically healthy.

\section{$\ddagger$ Risk Factor Assessment}

\section{fixed factors}

- family history - Mr. Tso has a family history of G.I. cancer. The patient's maternal aunt died from G.I. cancer.

\section{acquired factors}

- environmental - There are no environmental factors that contribute to the case.

- behavioral -

alcohol: Mr. Tso does not drink.

$>$ tobacco: He does not smoke.

$>$ caffeine: He drinks 2 cups of coffee per day.

$>$ illegal drugs: He does not use illegal drugs.

$>$ sexual: He has a monogamous sexual relationship with his wife.

$>$ exercise: He used to jog regularly.

> dietary habits: Mr. Tso's appetite has been poor for the past year.

- health maintenance - Mr. Tso rarely sees his physician. His immunizations are up-to-date.

- disease associated - non-contributory

- treatment associated -

> surgery: none

$>$ allergies: none

medications: Mr. Tso is currently not taking any medication. 


\section{PHYSICAL EXAM}

- height $=5^{\prime} 10^{\prime \prime}$

- temperature $=37^{\circ} \mathrm{C}$

- respiration $=24 / \mathrm{min}$.
- weight $=146 \mathrm{lbs}$.

- pulse = 96/min.

- blood pressure $=128 / 80$

- appearance: unremarkable

- head, eyes, ears, nose, throat (HEENT): He has a pale, smooth tongue.

- skin: Mr. Tso has pale skin and mucous membranes.

- neck: unremarkable

- chest: unremarkable

- cardiac: unremarkable

- abdomen: unremarkable

- extremities: The rest of the physical examination is normal except for the extremities. He has trouble with balance and difficulty knowing the position of his fingers and toes when his eyes are closed. He has a loss of vibrational sense at the ankles and wrists.

\section{DISCUSSION QUESTIONS}

1) How has the physical examination helped you? Do you want to change your rank order of hypotheses based on the physical exam? If so, explain.

2) What lab tests and/or investigations you would like to do now to test your hypotheses? What are your reasons for ordering the lab tests or investigations? How would you explain to Mr. Tso why these are necessary? 


\section{Lab Tests - continued:}

10) serum electrolytes

This test helps to assess fluid, electrolyte and acid-base imbalances.

11) anti-intrinsic factor antibodies

These antibodies are found in the serum of patients with pernicious anemia and other anti-immune disorders.

12) serum homocysteine

This test measures abnormal metabolism in folate or vitamin $B_{12}$ deficiency.

13) serum methylmalonic acid

This test measures abnormal metabolism in vitamin $B_{12}$ deficiency.

14) serum creatinine

This test of renal function helps to interpret homocysteine and methylmalonic acid results.

\section{具 Investigations:}

\section{1) Schilling test}

The first part of this test assesses vitamin $B_{12}$ absorption from the bowel by measuring urinary excretion of the vitamin following standard doses of radioactive and nonradioactive vitamin $\mathrm{B}_{12}$.

The test distinguishes between intrinsic factor deficiency and malabsorption syndromes. The second part of the test is used to confirm a deficiency of intrinsic factor.

Note to Tutor: Review the learning issues with the students before they leave Session I. Make sure that these are consistent with the Expected Learning Issues at the beginning of this case. 


\section{ANEXO 8}

\section{TUTOR DIALOGUES}

Every Third Wednesday of the Month at Noon in BMSB 147

New Topics Every Month)

A Forum for Tutors to Explore and Discuss Issues and Problems in the Tutorial Process

KEY INGREDIENTS for Successful Tutorials

- Getting Started

- Case Discussion

- Learning Issues \& Closure

- Assessment-Why is it so Hard?

- Evaluation of Tutors by Students and Peers

\section{INFRASTRUCTURE \& SUPPORT}

- What are the Most Helpful Resources in Tutorial?

- Using Lectures to Enhance Tutorials

- What makes a Good Tutorial Case?

- Tutoring in the Clinical Setting

\section{REFLECTIVE ANALYSIS}

- Common Problems \& Strategies in Tutorials

- What Makes Tutorials Work in Different Settings?

- How to Introduce Behavioral \& Population Issues in Tutorials

- Is Student-Centered, Problem-Based Learning Happening in Tutorials?

\section{TECHNIQUES FOR TUTORING}

- Co-Tutoring: What Works, What Doesn't

- Advanced Skills for tutoring Outside your Comfort Zone

- Skills for Tutorials with Advanced Students

- Pearls, Perils and Pitfalls of "Short Term Tutoring"

\section{TUTORIAL DYNAMICS}

- Facilitating Quiet \& Aggressive Students

- Recognizing \& Dealing with Dysfunctional Tutorial Groups

- Tutoring "Burned Out" Students

\section{DISCUSSION TOOLS}

- Enhancing Tutoring Skills through Video

- Skills to Enhance Problem-Based Learning (electronic journal article) 


\section{GUIDE FOR ASSESSMENT IN TUTORIALS \\ (Observable behaviors)}

\section{KNOWLEDGE BASE}

- Integrates the three major perspectives of medical sciences (biologic, behavioral, population) in cases and discussions.

- Demonstrates understanding of issues across levels of organization (e.g., cellular and molecular, gross and microscopic; individual-family-community, organic and behavioral).

- Summarizes issues succinctly.

\section{REASONING PROCESS}

- Uses evidence to support reasoning.

- $\quad$ Responds to uncertainty with a plan (e.g., identifies problem, formulates hypotheses, tests hypotheses, and re-evaluates using written, personal, or electronic resources).

- Uses reasoning process as part of the presentation/discussion of learning issues.

- Relates learning issues to the patient case or problem(s).

- Regularly develops learning issues.

- Challenges others' concepts and ideas in a constructive way.

\section{COMMÜNICATION}

- Uses correct terminology, pronunciation, and spelling.

- Uses the board, diagrams, and AV aids.

- Uses listening skills.

- Uses communication skills.

- Demonstrates team/helping behaviors.

\section{ASSESSMENT SKIILLS}

- Practices self, peer, and group assessment.

- Addresses observable behaviors.

- Articulates own biases and values.

- Articulates self-awareness relative to the group.

- Provides evidence of following a plan for improvement. 


\section{Knowledge Base}

Integrates the three perspectives (biology, population, behavior) in cases and discussions.

Defines major/relevant learning issues for each perspective.

Gives examples from case of how one perspective might affect or interact with another.

Develops management strategy to address the three perspectives.

Demonstrates understanding of issues across levels of organization (e.g. cellular and molecular: gross and microscopic: individual-family-community, organic and behavioral), evidenced as follows:

Diagrams mechanisms using flow charts and other visual aids.

Demonstrates understanding of key or rate-limiting steps.

Summarizes issues succinctly.

Uses summary for clarification, checking understanding, closure, or to set the stage for discussion.

Presents case summaries that are concise and logical (i.e., have a beginning, middle, and end) and relates the learning issues/facts (i.e., the details) to the patient's story (i.e., the big picture).

Develops concise/specific learning issues by formulating questions that can be answered in the available time.

Clarifies, focuses, and refines learning issues.

Tutorial Steering Committee

O 1995 The University of New Mexico School of Medicine 


\section{Reasoning Process}

Uses evidence to support reasoning.

Supports reasoning and conclusions with relevant and specific information.

Provides sources(s) of information cited.

Responds to uncertainty with a plan (e.g. identifies problem. formulates hypotheses, tests hypotheses, and re-evaluates using written. personal, or electronic resources), evidenced as follows:

Describes steps taken in seeking information.

Selects resources that are relevant to group's level of understanding.

Able to choose from a variety of resources.

Discerns relative value of resources used.

Uses reasoning process as part of the presentation/discussion of learning issues, evidenced as follows:

Develops a plan and method for presenting learning issues which is understood by group.

Conveys what is to be presented in a clear manner.

- Balances the level of detail to the needs of the group.

Presents in a logical, step-wise manner (i.e., articulates starting and end point of presentation).

Reiterates \& checks others' understanding of learning issues.

Relates learning issues to patient cases or problems.

Regularly develops learning issues.

Asks key questions.

Interacts with group to further define and "fine tune" learning issues.

Works to prioritize learning issues.

Challenges others' concepts and ideas in a constructive way. 


\section{Communication}

Uses correct terminology, pronunciation, and spelling.

Uses the board, diagrams, and AV aids as follows:

Diagrams transferred to board without notes are helpful, unique/original, easily understood, clearly labeled.

Spontaneously uses board when necessary to graphically demonstrate difficult concepts with little or no prompting.

Provides concise summary materials and uses them to facilitate group learning.

Uses listening skills as follows:

Asks follow-up questions or clarifying questions.

Re-iterates/paraphrases to check understanding.

Makes connections between information from different sources.

Uses communication skills as follows:

Stays focused on topic at hand.

Makes explicit the relationship of own and others' contributions to previously discussed material. ("This new information is important because...")

Explanations are clear and easily understood.

Checks others' understanding, responds to lack of understanding in helpful manner, facilitating the learning of others.

Demonstrates team-building/helping behaviors as follows:

Facilitates the learning of others using:

- Questions which probe the level of understanding of conceptual material, as well as grasp of details.

- Summarization.

Brings unique/original resources to group.

Creates a safe environment for others' learning.

Responds constructively to verbal and non-verbal communication in the group. 